\title{
Ultrasound-guided foam sclerotherapy for treating varicose veins
}

Citation for published version (APA):

Shadid, N. (2013). Ultrasound-guided foam sclerotherapy for treating varicose veins. [Doctoral Thesis, Maastricht University]. Maastricht University. https://doi.org/10.26481/dis.20131120ns

Document status and date:

Published: 01/01/2013

DOI:

10.26481/dis.20131120ns

Document Version:

Publisher's PDF, also known as Version of record

\section{Please check the document version of this publication:}

- A submitted manuscript is the version of the article upon submission and before peer-review. There can be important differences between the submitted version and the official published version of record.

People interested in the research are advised to contact the author for the final version of the publication, or visit the DOI to the publisher's website.

- The final author version and the galley proof are versions of the publication after peer review.

- The final published version features the final layout of the paper including the volume, issue and page numbers.

Link to publication

\footnotetext{
General rights rights.

- You may freely distribute the URL identifying the publication in the public portal. please follow below link for the End User Agreement:

www.umlib.nl/taverne-license

Take down policy

If you believe that this document breaches copyright please contact us at:

repository@maastrichtuniversity.nl

providing details and we will investigate your claim.
}

Copyright and moral rights for the publications made accessible in the public portal are retained by the authors and/or other copyright owners and it is a condition of accessing publications that users recognise and abide by the legal requirements associated with these

- Users may download and print one copy of any publication from the public portal for the purpose of private study or research.

- You may not further distribute the material or use it for any profit-making activity or commercial gain

If the publication is distributed under the terms of Article $25 \mathrm{fa}$ of the Dutch Copyright Act, indicated by the "Taverne" license above, 


\section{Ultrasound-guided foam slerotherapy for treating varicose veins}

Nadia Shadid 
Financial support for printing this thesis kindly provided by:

AbbVie BV, Astellas Pharma BV, Bauerfeind Benelux BV, biolitec medical technology GmbH, Bo Medical Technologies BV, Esaote Benelux BV, Fagron BV, Louis Widmer Nederland, medi Nederland BV, Tobrix BV, Vinger aan de Pols compressie kousen en bandages

ISBN/EAN: 978-90-9027892-6

Cover design: Tineke Shadid-Mijnssen

Cover layout: Henk Jan Drenthen

Layout and printing: Pasmans Drukkerij, Den Haag

Copyright $\odot 2013$ N.H. Shadid, The Hague, The Netherlands.

All rights reserved. No part of this thesis may be reproduced, stored, or transmitted in any form or by any means without prior written permission of the author. 


\title{
Ultrasound-guided foam sclerotherapy for treating varicose veins
}

\author{
PROEFSCHRIFT
}

ter verkrijging van de graad van doctor

aan de Universiteit Maastricht

op gezag van de Rector Magnificus Prof. dr. L.L.G. Soete

volgens het besluit van het College van Decanen,

in het openbaar te verdedigen op

woensdag 20 november 2013 om 14.00 uur

door

Nadia Henriëtte Shadid

geboren te Middelburg 


\section{Promotor:}

Prof. dr. P. M. Steijlen

\section{Copromotores:}

Dr. A. Sommer

Dr. P.J. Nelemans

\section{Beoordelingscommissie:}

Prof. dr. C.H.A. Wittens (voorzitter)

Dr. A.J. ten Cate-Hoek

Prof. dr. M. de Haan

Prof. dr. M.G.R. de Maeseneer (Erasmus MC Rotterdam)

Prof. dr. H.A.M. Neumann (Erasmus MC Rotterdam) 
Aan mijn ouders 



\section{Contents}

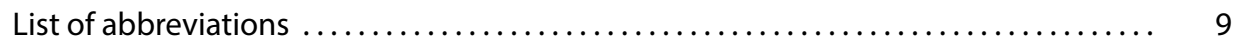

Chapter 1

Introduction

\section{Chapter 2}

Foam echosclerotherapy for trunkvaricositas.

\section{Chapter 3}

Randomized clinical trial of ultrasound-guided foam sclerotherapy versus

surgery for the incompetent great saphenous vein ...

\section{Chapter 4}

How specific are venous symptoms for diagnosis of CVD?

\section{Chapter 5}

Superficial thrombophlebitis of the venous dorsal arch of the foot and deep venous thrombosis after foam sclerotherapy. .

\section{Chapter 6}

In vivo effects of foam sclerotherapy on coagulation

\section{Chapter 7}

Predictors of recurrence of great saphenous vein reflux following treatment with ultrasound-guided foamsclerotherapy. .

\section{Chapter 8}

Discussion

\section{Chapter 9}

Summary

\section{Chapter 10}

Samenvatting.

List of publications and oral presentations

Curriculum Vitae 


\section{List of abbreviations}

$\begin{array}{ll}\text { AASV } & \text { anterior accessory saphenous vein } \\ \text { CAT } & \text { Calibrated Automated Thrombography } \\ \text { CEAP } & \text { clinical etiologic anatomic pathofysiologic } \\ \text { CVI } & \text { chronic venous insufficiency } \\ \text { DVT } & \text { deep venous thrombosis } \\ \text { ETP } & \text { endogenous thrombin potential } \\ \text { EVLA } & \text { endovenous laser ablation } \\ \text { GSV } & \text { great saphenous vein } \\ \text { MIPA's } & \text { microparticles } \\ \text { Peak } & \text { peak hight } \\ \text { RFA } & \text { radiofrequency ablation } \\ \text { SFJ } & \text { saphenofemoral junction } \\ \text { SSV } & \text { small saphenous vein } \\ \text { TAT complexes } & \text { thrombin anti-thrombin complexes } \\ \text { UGFS } & \text { ultrasound guided foam sclerotherapy } \\ \text { VAS } & \text { visual analogue scale } \\ \text { VCSS } & \text { venous clinical severity score } \\ \text { vWfAg } & \text { Von Willebrand factor }\end{array}$





Venous disease is among the most common medical conditions to affect mankind; approximately $1-3 \%$ of the population of the Western world is estimated to have severe venous problems at some point in their lives ${ }^{1}$. Clinical manifestations range from asymptomatic varicose veins to venous ulceration. Varicose veins are the most common manifestation of CVI. Varicose veins have incompetent valves causing increased venous pressure which may lead to progressive vessel dilatation and tortuosity, skin changes and sometimes to ulceration. Venous disease is often the cause of discomfort, pain, loss of working days, and deterioration of health-related quality of life 2,3 . The treatment of symptomatic varicose veins imposes a high burden on health care budgets. In European countries venous disease consumes $1-2 \%$ of the health care budgets ${ }^{4}$.

For many years surgical treatment was the gold standard in treating varicose veins. Since the introduction of ultrasound examination in the early 1980s in patients suffering from varicose veins a better understanding has been gained concerning the underlying pathology of the clinical presentation in patients with venous disorders. For the physician it became possible to visualize the pathologic flow in the venous system and subsequently treatments could become minimally invasive, as they could now be performed intraluminally under ultrasound guidance. These therapies have quickly gained popularity and are used with increasing frequency including chemical and thermal ablation of the treated vessel. Chemical ablation is performed by using ultrasound guided foam sclerotherapy (UFGS), and thermal ablation by endovenous laser ablation (EVLA) and radiofrequency ablation (RFA). These treatment options have in common that they aim at obliterating veins with reflux. Nowadays minimally invasive techniques are favoured by both physicians and patients and replace surgical methods. The rapid development towards frequent use of these alternative treatments of varicose veins warrants evaluation of efficacy, safety and costs when compared with surgery.

\section{Epidemiology}

The term chronic venous insufficiency (CVI) describes a medical condition in which venous hypertension affects the venous system of the lower limbs causing various symptoms including pain, swelling, oedema, skin changes, and ulcerations ${ }^{5}$. CVI represents the full spectrum of manifestations of chronic venous disease, but the term CVI is frequently used to exclude uncomplicated varicose veins. Although numerous epidemiological studies have been conducted it is difficult to determine the exact prevalence of chronic venous disease. Prevalence depends on the distribution of risk factors in the population including female gender, obesity, older age, pregnancy and deep venous thrombosis ${ }^{6}$. A cross sectional survey in Edinburgh also known as the Edinburgh vein study showed that the prevalence 
of varicosis of the great or small saphenous vein was $40 \%$ in men and $32 \%$ in women and increases with age ${ }^{7}$.

The clinical manifestations of varicose veins vary broadly from relatively mild disease to more advanced skin changes and ulceration. In more than $60 \%$ of the population patients have mild venous disease, with no clinical signs at all or only the presence of teleangiectatic or reticular veins. Skin changes caused by venous disease, including venous ulcers, are found in less than $10 \%$ and the prevalence for healed ulcers ranges from $0.6 \%-1.4 \%$ and is estimated to be about $0.5 \%$ for active ulcers ${ }^{7-10}$. The overall prognosis of venous ulcers is poor, more than $50 \%$ of venous ulcers require prolonged therapy for more than a year ${ }^{11}$. The total costs of this end stage of venous disease covers $1 \%$ of the total annual health care budget in Western European countries ${ }^{12}$.

The rate of progression from uncomplicated varicose veins into complicated venous pathology accompanied by skin changes and ulceration remains poorly defined ${ }^{13}$. The most reliable data on the natural course probably come from the population based Bonn Vein Study II in which an incidence of CVI progression from C1-C2 to C3-C6 of 2\% per year within 6 years was reported ${ }^{14}$.

\section{Pathophysiology}

It seems that the basic pathophysiology of venous disorders have already been fairly understood by the ancients. A statement of Hippocrates was: "it was better not to stand in the case of an ulcer on the leg"15. The veins of the lower extremity are divided into the superficial and deep venous system connected by a series of perforator veins. The two major superficial veins are small saphenous vein (SSV) and the great saphenous vein (GSV) (see Figure 1). The deep venous system is located underneath the muscular fascia and functions as collecting system for the venous outflow of the extremities. The superficial veins are connected to the deep venous system by a number of perforating veins in the thigh. Bicuspid valves and muscle pumps in the venous system ensure that blood flows in the direction of the heart, preventing the return of blood toward the feet in upright position ${ }^{16}$. Failure of the valves results in pathological retrograde venous flow (reflux) and venous hypertension. In the upright position and in the absence of muscle contraction venous hydrostatic pressure measured on the dorsum of the foot ranges from $90-120 \mathrm{mmHg}$, depending on the individual's height ${ }^{17}$. In the normal limb during ambulatory calf contractions mean venous pressure is reduced to $22 \mathrm{mmHg}^{18}$. In patients with CVI this pressure will not further decrease than $60-70 \mathrm{mmHg}$. This venous hypertension can be caused by valvular incompetence of the axial deep or superficial veins, perforator valve incompetence, venous obstruction or a combination of these factors. 


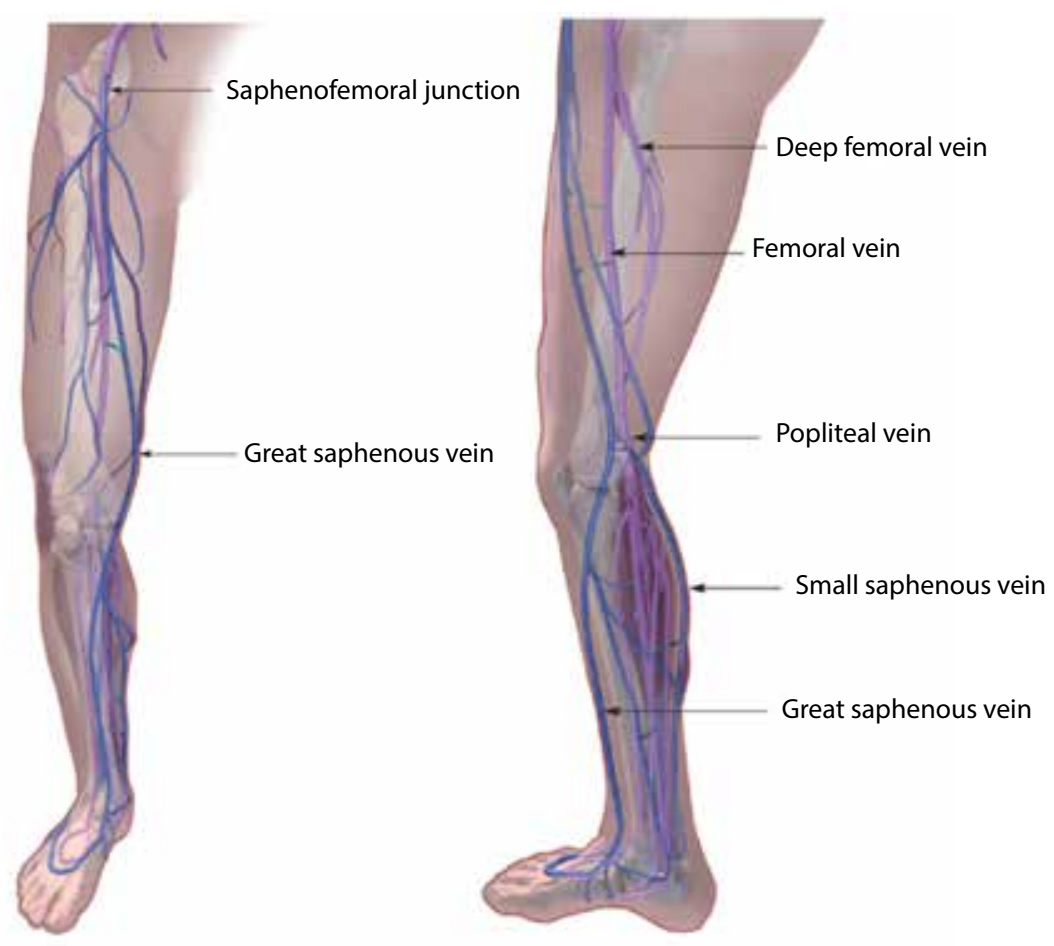

Figure 1. venous anatomy of lower extremities

Venous hypertension results in micro circulatory hemodynamic disturbances eventually leading to skin changes such as pigmentations, lipodermatosclerosis, atrophie blanche and venous ulcers ${ }^{19,20}$. Until now few studies have been performed on the clinical and haemodynamic effects of abolishing reflux on venous hypertension. In theory the abolishing of reflux should improve ulcer healing and prevent the progression of CVI. However there are no relevant studies that demonstrate a lessening effect of compression or surgical/ endovenous interventions on the progression of $\mathrm{CVI}^{13}$. There is evidence that abolishing reflux does not increase the healing rate of venous ulcers but decreases significantly the risk of ulcer recurrence ${ }^{21}$.

\section{Clinical signs and symptoms}

$\mathrm{CVI}$ of the lower limbs is characterized by symptoms and/or signs produced by venous hypertension as a result of structural or functional abnormalities of veins. Symptoms may include heaviness, leg-tiredness, cramps, aching, itching, restless leg syndrome and 

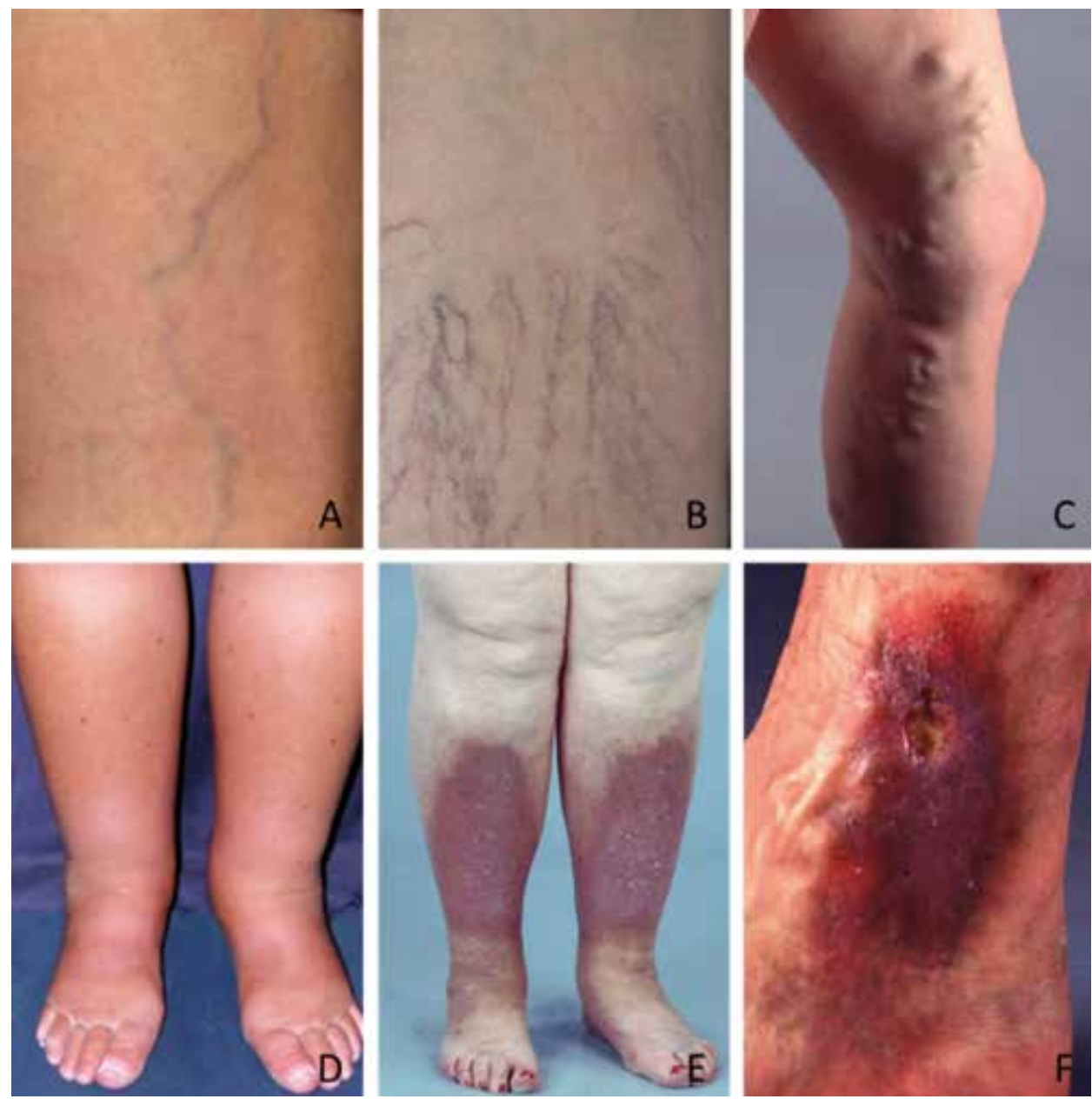

Figure 2. Clinical characteristics of chronic venous disease. A. Teleangiectases. B. Reticular veins. C. Varicose veins. D. Edema. E. Lipodermatosclerosis and hyperpigmentation. F. Ulceration

swelling in the leg. Clinical signs of CVI may include teleangiectasia, reticular or varicose veins, edema and skin changes such as pigmentation, lipodermatosclerosis, eczema and ulceration (see Figure 2).

None of the venous symptoms are pathognomic for varicose veins and the relation between CVI signs and symptoms is not very strong. In large population based studies similar symptoms have been noted in participants without varicose veins ${ }^{22,23}$. 


\section{Classification}

Since 1994 the CEAP classification is widely used in practice and scientific settings and is the gold standard to classify stages of venous diseases. This classification combines the manifestation of different clinical stages and underlying aetiology and pathology. In 2004, the basic CEAP classification has been revised (Table 1). However, its components have been recognized to be relatively incapable for monitoring changes in venous disease severity ${ }^{24}$.

Table 1. CEAP classification of chronic venous disease

\section{Clinical classification}

C0 No visible or palpable signs of venous disease

C1 Teleangiectases or reticular veins

C2 Varicose veins

C3 Edema

C4a Pigmentation and/or eczema

C4b Lipodermatosclerosis and/or atrophie blanche

C5 Healed venous ulcer

C6 Active venous ulcer

S Symptomatic, including ache, pain, tightness, skin irritation, heaviness, muscle cramps, as well as other complaints attributable to venous dysfunction

A Asymptomatic

\section{Etiologic classification}

Ec Congenital

Ep Primary

Es Secondary (postthrombotic)

En No venous etiology identified

Anatomic classification

As Superficial veins

Ap Perforator veins

Ad Deep veins

An No venous location identified

\section{Pathophysiologic classification}

Pr Reflux

Po Obstruction

Pr,o Reflux and obstruction

Pn No venous pathophysiology identifiable

Advanced CEAP: Same as basic CEAP, with addition that any of 18 named venous segments can be used as locators for venous pathology. 


\section{Diagnostic evaluation}

Many of the signs and symptoms of CVI can be detected by physical examination, which still plays an important role in diagnosis. However it does not provide information about the anatomic extent of disease involving the deep and superficial venous systems. Duplex ultrasound is the test of choice for evaluation of varicose veins as it is safe, noninvasive, cost-effective, and reliable. It enables distinction between congenital, primary, and secondary causes of CVD in the majority of cases ${ }^{6}$. The optimal position to perform duplex ultrasonography is a standing position where both reflux and obstruction can be evaluated in the deep, superficial and perforating veins. Reflux can be elicited in two ways. With the Valsava method the intra-abdominal pressure is increased and in case of valvular incompetence, this may lead to reversal flow. The other way is to give manual compression distal to the point of examination, resulting in an initial increase of flow in the vein as the blood is pushed in the normal direction of flow. If the pressure is released, the blood flow reverses momentarily. In case of incompetent valves the blood continues to flow in reverse direction. The duration of reflux is known as the reflux time. A reflux time of $>0.5 \mathrm{~s}$ is being used to diagnose the presence of reflux.

\section{Development of treatment}

As early as the first century AD, a famous Roman encyclopaedist, Aurelius Cornelius Celsus, used avulsion with a hook or a touch of a cautery to treat varicose veins ${ }^{25}$. In Byzantine times a Greek surgeon (607-690) recognized that ligation and removal of the great saphenous vein was important ${ }^{26}$. A first attempt to sclerotherapy, was already made in 1864 by the Frenchman Pravaz ${ }^{27}$. This method causes thrombus formation by injecting a sclerosant. In the early twentieth century, stripping of the saphenous veins was added to proximal ligation of the saphenofemoral junction. After development of several strippers in 1907 the "Babcock" stripper was introduced, a flexible internal stripper ${ }^{28}$. This stripper can be regarded as the prototype of all strippers that are currently in use. Following these early years attempts at devising a suitable stripping technique the pendulum swung back to sclerotherapy. In the 1930 s it even became the treatment of choice, the used sclerosant was sodium morrhuate 29 .

After the 50s surgery gained more interest caused by publications which were nearly all in favour of the stripping technique ${ }^{30,31}$. For decades a high ligation of the saphenofemoral junction (SFJ) and short stripping of the GSV was the standard procedure for treating GSV reflux and is till today the gold standard. Studies on long-term results of surgery indicated recurrence rates of between $21 \%$ and $26 \%$ after 3 years and $60 \%$ after 34 years ${ }^{32-34}$. Recurrence rates after GSV stripping are usually caused by neovasularization at the saphenofemoral junction (SFJ) stimulated by surgical dissection in this area ${ }^{35}$. Despite the good results of 
stripping, surgery has some disadvantages. Varicose vein surgery is often performed as a day case procedure under general or epidural anesthesia.There is a risk of temporary or sometimes permanent cutaneous nerve injury after stripping which occurs in $5-7 \%$ of cases $^{36}$. Other complications may occur such as groin infection, haematoma and postoperative pain ${ }^{37}$. Another disadvantage of surgery is the post-operative downtime, most patients are advised to resume their daily activities after 1 week which can be associated with considerable inconvenience and indirect health care costs ${ }^{38}$.

Because of these disadvantages of surgery and the introduction of duplex ultrasound in the 80 's minimally invasive techniques have gained popularity and are used with increasing frequency. Ultrasound guided foamsclerotherapy (UGFS), radiofrequency ablation (RFA) and endovenous laser ablation (EVLA) are such minimally invasive techniques. In nonrandomized studies these techniques were reported to be successful in $69 \%-93 \%$ of patients at two years after treatment ${ }^{39-41}$. An advantage is that no general anaesthesia or hospital stay is needed.

UGFS sclerotherapy with foam is a novel further development of traditional sclerotherapy. Foam is a variant of liquid sclerotherapy in which the liquid-air mixture (foam) is injected in varicose veins under ultrasound guidance. Orbach already made an attempt in 1940 with his air-block technique to displace the blood column to intensify the contact between the sclerosant and endothelium ${ }^{42}$. In 1995 Cabrera produced microfoam and reported about the clinical effectiveness in a series of 500 patients with larger varicose veins ${ }^{43}$.This is a variant of liquid sclerotherapy in which the liquid-air mixture (foam) is injected in varicose veins under ultrasound guidance. Compared with liquid sclerotherapy, UGFS is much more effective ${ }^{44,45}$.

A major advantage of UGFS is that this technique is easy to perform and easy to learn. which makes it an accessible treatment modality for a large group of specialists involved in the treatment of varicose vein. This development of an easy-to-use and accessible technique to treat varicose veins instigated the need for comparison of foam sclerotherapy with surgery in a non-inferiority randomized controlled trial. In exchange for certain advantages, such as fewer side effects, more convenience and less healthcare costs as a society we may be willing to accept some loss in effectiveness, but it is necessary to make sure, that such a loss does not exceed a predefined margin. 


\section{Aims of the thesis}

This thesis will focus on UGFS as treatment modality for patients with varicose veins. The main objective was to evaluate effectiveness and healthcare costs in the treatment of the incompetent GSV. Secondary objectives were to explore safety in terms of the effect of foam injection on coagulability of blood and to identify predictors of treatment success after UGFS.

\section{Outline of the thesis}

Chapter 2 describes a Dutch consensus for the physician who is performing UGFS treatments. This consensus was written to achieve standardization of the treatment. $A$ consensus meeting was held by experts. Based on their clinical experiences and a literature study a Dutch consensus was drawn up.

Chapter 3 reports the results of a large multi-centre randomised non-inferiority trial comparing effectiveness and health care costs of surgery versus UGFS in the treatment of primary greater saphenous vein incompetence with a follow-up period of 2 years

Chapter 4 evaluates whether and which leg symptoms commonly attributed to a venous cause are characteristic for patients with chronic venous insufficiency (CVI). The VEINESSym part of the VEINES-QOL/Sym questionnaire was used to evaluate the frequency of nine venous symptoms reported by CVI patients. These frequencies were compared to those reported by patients with other diseases of the lower legs, such as arthrosis, peripheral arterial disease and spinal disc herniation.

Chapter 5 describes a case report of a patient with a superficial thrombophlebitis and deep venous thrombosis after UGFS.

Chapter 6 presents the results of a study on the in vivo effects of UGFS on blood coagulability. Changes from baseline in parameters that measure thrombin generation were assessed in patients who were treated with foam sclerotherapy.

Finally, the aim of chapter $\mathbf{7}$ was to identify predictors of treatment success after UGFS. Such predictors can be used for selection of patients who are most likely to benefit from treatment with this modality

Chapter 8 provides a general discussion about the findings of this thesis.

Chapter 9 provides a summary of this thesis. 


\section{References}

1. Callam MJ. Epidemiology of varicose veins. Br J Surg. 1994;81(2):167-73.

2. Smith JJ, Guest MG, Greenhalgh RM, Davies AH. Measuring the quality of life in patients with venous ulcers. J Vasc Surg. 2000;31(4):642-9.

3. Kaplan RM, Criqui MH, Denenberg JO, Bergan J, Fronek A. Quality of life in patients with chronic venous disease: San Diego population study. J Vasc Surg. 2003;37(5):1047-53.

4. Ruckley CV. Socioeconomic impact of chronic venous insufficiency and leg ulcers. Angiology 1997;48(1): 67-9.

5. Eberhardt RT, Raffetto JD. Chronic venous insufficiency. Circulation. 2005;111(18):2398-409.

6. Meissner MH, Gloviczki P, Bergan J, Kistner RL, Morrison N, Pannier F, et al. Primary chronic venous disorders. J Vasc Surg. 2007;46 Suppl S:54S-67S.

7. Fowkes FG, Evans CJ, Lee AJ. Prevalence and risk factors of chronic venous insufficiency. Angiology 2001;52 Suppl 1:S5-15.

8. Chiesa R, Marone EM, Limoni C, Volonte M, Schaefer E, Petrini O. Chronic venous insufficiency in Italy: the 24-cities cohort study. Eur J Vasc Endovasc Surg. 2005;30(4):422-9.

9. Rabe E, Pannier-Fischer F, Bromen K. Bonner Venenstudie der Deutschen Gesellschaft fur Phlebologieepidemiologische Untersuchung zur Frage der Haufigkeit und Auspragung von chronischen Venenkrankheiten in der stadtischen und landlichen Wohnbevolkerung. Phlebologie. 2003;32:1-14.

10. Carpentier PH, Maricq HR, Biro C, Poncot-Makinen CO, Franco A. Prevalence, risk factors, and clinical patterns of chronic venous disorders of lower limbs: a population-based study in France. J Vasc Surg. 2004;40(4):650-9.

11. Scott TE, LaMorte WW, Gorin DR, Menzoian JO. Risk factors for chronic venous insufficiency: a dual casecontrol study. J Vasc Surg. 1995;22(5):622-8.

12. Nelzen O. Leg ulcers: economic aspects. Phlebology 2000;15:110-4.

13. Neglen P, Eklof B, Kulwicki A, Davies A, Deschamps T, Garcia M, et al. Prevention and treatment of venous ulcers in primary chronic venous insufficiency. J Vasc Surg. 2010;52(5 Suppl):15S-20S.

14. Meissner MH. What is the medical rationale for the treatment of varicose veins? Phlebology 2012;27 Suppl 1:27-33.

15. Adams F. The Genuine Works of Hippocrates. Baltimore, MD: Williams and Wilkins. 1939.

16. Lim CS, Davies AH. Pathogenesis of primary varicose veins. Br J Surg. 2009;96(11):1231-42.

17. Nicolaides AN. Investigation of chronic venous insufficiency: A consensus statement (France, March 5-9, 1997). Circulation. 2000;102(20)

18. Pollack AA, Wood EH. Venous pressure in the saphenous vein at the ankle in man during exercise and changes in posture. J Appl Physiol. 1949;1(9):649-62.

19. Pappas PJ, N. DW, W. HR. Pathology and cellular physiology of chronic venous insufficiency. In Gloviczki P, Yao JS, eds Handbook of Venous Disorders. 2001;2nd ed. New York, NY: Arnold; 2001: 49-57.

20. Gschwandtner ME, Ehringer H. Microcirculation in chronic venous insufficiency. Vasc Med. 2001;6(3): 169-79.

21. Gohel MS, Barwell JR, Taylor M, Chant T, Foy C, Earnshaw JJ, et al. Long term results of compression therapy alone versus compression plus surgery in chronic venous ulceration (ESCHAR): randomised controlled trial. BMJ. 2007;335(7610):83.

22. Bradbury A, Evans $C$, Allan P, Lee A, Ruckley CV, Fowkes FG. What are the symptoms of varicose veins? Edinburgh vein study cross sectional population survey. BMJ. 1999;318(7180):353-6.

23. Langer RD, Ho E, Denenberg JO, Fronek A, Allison M, Criqui MH. Relationships between symptoms and venous disease: the San Diego population study. Arch Int Med. 2005;165(12):1420-4.

24. Eklof B, Rutherford RB, Bergan JJ, Carpentier PH, Gloviczki P, Kistner RL, et al. Revision of the CEAP classification for chronic venous disorders: consensus statement. J Vasc Surg. 2004;40(6):1248-52.

25. Anning S. Historical aspects. In: Dodd H, Cockett FB eds The Pathology and Surgery of Veins of the Lower Limb Edinburgh. 1956; Livingstone(1956):6-28.

26. Lascaratos J, Liapis C, Kouvaraki M. Surgery on varices in Byzantine times (324-1453 CE). J Vasc Surg. 2001;33(1):197-203. 
27. Chapman HT. Varicose Veins, Their Nature, Consequence and Treatment. London: Churchill. 1864.

28. Babcock W. A new operation for the extirpation of varicose veins of the leg. NY Med J. 1907;86:153-6.

29. Van de Bremer J, Moll FL. Historical overview of varicose vein surgery. Ann Vasc Surg 2010 Apr;24(3):426-32.

30. Lofgren KA, Ribisi AP, Myers TT. An evaluation of stripping versus ligation for varicose veins. AMA Arch Surg. 1958;76(2):310-6.

31. Hobbs JT. Surgery and sclerotherapy in the treatment of varicose veins. A random trial. Arch Surg. 1974;109(6):793-6.

32. van Rij AM, Jiang P, Solomon C, Christie RA, Hill GB. Recurrence after varicose vein surgery: a prospective long-term clinical study with duplex ultrasound scanning and air plethysmography. J Vasc Surg. 2003; 38(5):935-43.

33. Neglen P. Long saphenous stripping is favored in treating varicose veins. Dermatol Surg 2001;27(10):901-2.

34. Fischer R, Linde N, Duff C, Jeanneret C, Chandler JG, Seeber P. Late recurrent saphenofemoral junction reflux after ligation and stripping of the greater saphenous vein. J Vasc Surg. 2001;34(2):236-40.

35. Jones L, Braithwaite BD, Selwyn D, Cooke S, Earnshaw JJ. Neovascularisation is the principal cause of varicose vein recurrence: results of a randomised trial of stripping the long saphenous vein. Eur J Vasc Endovasc Surg. 1996;12(4):442-5.

36. Holme JB, Skajaa K, Holme K. Incidence of lesions of the saphenous nerve after partial or complete stripping of the long saphenous vein. Acta Chir Scand. 1990;156(2):145-8.

37. Beale RJ, Gough MJ. Treatment options for primary varicose veins--a review. Eur J Vasc Endovasc Surg. 2005;30(1):83-95.

38. Shadid N, Ceulen R, Nelemans P, Dirksen C, Veraart J, Schurink GW, et al. Randomized clinical trial of ultrasound-guided foam sclerotherapy versus surgery for the incompetent great saphenous vein. $\mathrm{Br} J$ Surg. 2012;99(8):1062-70.

39. Min RJ, Khilnani N, Zimmet SE. Endovenous laser treatment of saphenous vein reflux: long-term results. J Vasc Interv Radiol. 2003;14(8):991-6.

40. Hamel-Desnos C, Ouvry P, Benigni JP, Boitelle G, Schadeck M, Desnos P, et al. Comparison of $1 \%$ and $3 \%$ polidocanol foam in ultrasound guided sclerotherapy of the great saphenous vein: a randomised, doubleblind trial with 2 year-follow-up. “The 3/1 Study". Eur J Vasc Endovasc Surg. surgery 2007;34(6):723-9.

41. Lurie F, Creton D, Eklof B, Kabnick LS, Kistner RL, Pichot O, et al. Prospective randomised study of endovenous radiofrequency obliteration (closure) versus ligation and vein stripping (EVOLVeS): two-year follow-up. Eur JVasc Endovasc Surg. 2005;29(1):67-73.

42. Wollmann JC. The history of sclerosing foams. Dermatol Surg 2004;30(5):694-703

43. Cabrera J, Cabrera J, Garcia Olmedo M. Treatment of varicose long saphenous veins with sclerosants in microfoam: long term outcomes. Phlebology 2000;15:19-23.

44. Rabe E, Otto J, Schliephake D, Pannier F. Efficacy and Safety of Great Saphenous Vein Sclerotherapy Using Standardised Polidocanol Foam (ESAF): A Randomised Controlled Multicentre Clinical Trial. Eur J Vasc Endovasc Surg. 2007.

45. Yamaki T, Nozaki M, Iwasaka S. Comparative study of duplex-guided foam sclerotherapy and duplexguided liquid sclerotherapy for the treatment of superficial venous insufficiency. Dermatol Surg 2004;30(5):718-22. 




\section{Chapter 2}

\section{Foam echosclerotherapy for trunkvaricositas}

Nadia Shadid, Anja Sommer

Ned Tijdschr Geneeskd. 2009;153:B99. Review. Dutch. 


\section{Abstract}

Foam sclerotherapy is increasingly being used to treat truncal varices, in view of its minimally invasive nature and the high success rate in terms of occlusion of varicose veins treated with this technique. To achieve standardization of the treatment, a consensus meeting was organized with Dutch experts. Based on their clinical experiences and literature data, the Dutch consensus statement presented here was drawn up. This consensus statement provides a guideline for the treatment of truncal varices with foam sclerotherapy and an overview of this new technique for specialists as well as general practitioners. 


\section{Introduction}

Chronic venous insufficiency (CVI) is characterized by various types of varices, some with associated skin abnormalities, which may in some cases even lead to venous ulcers. ${ }^{1}$ Varicose veins represent a burden to a large proportion of the population, with incidences of up to $50 \%$, rising with age. ${ }^{2}$ One in 10 of the affected persons reports varices-related symptoms that require treatment. Symptoms include a feeling of heaviness and fatigue in the legs, spasms, restless legs and venous claudication. The treatment consists of elimination of the underlying venous hypertension, which is often caused by truncal varices.

The gold standard for the treatment of primary truncal varices has always been surgical intervention. A new therapeutic option for truncal varices is foam sclerotherapy, a form of ultrasound guided sclerotherapy in which the sclerosant is mixed with air to create a foam. ${ }^{3}$ In the Netherlands, foam sclerotherapy is applied by surgeons, dermatologists and radiologists. Compared to surgical interventions, the treatment is minimally invasive, patient-friendly and cost-effective. ${ }^{4}$ It is a suitable treatment for truncal varices, recurrent varices after surgery, teleangiectases/reticular veins and perforating vein varices, and is also used in some clinics for venous malformations and pelvic varices. ${ }^{3}$ More and more Dutch clinics have adopted foam sclerotherapy as a treatment for varicose veins, sometimes as an alternative to surgical intervention. There is, however, no standardized management policy for ultrasound-guided sclerotherapy in practice in the Netherlands. A consensus meeting was therefore held with experts in the field of ultrasound-guided foam sclerotherapy (vascular surgeons, radiologists and dermatologists) to draw up a Dutch consensus statement on the treatment of truncal varices, based on literature data (from PubMed) and the experts' own experiences. This consensus statement can be used as a practice guideline.

\section{Indications}

Ultrasound-guided foam sclerotherapy can be used for a variety of varices, ranging from reticular veins to truncal varices. ${ }^{5}$ This consensus statement only relates to the treatment of truncal varices, which is the most common indication. A few rare indications like venous malformations can also be treated with foam sclerotherapy, but require referral to specialized centres.

\section{Preparing the foam}

In the Netherlands, the foam is prepared by mixing the sclerosant polidocanol with air.5,6 After intravenous administration, it causes destruction of the endothelial cells, which leads to thrombus formation and eventually to a fibrotic cord.7 Foam is prepared using the Tessari 


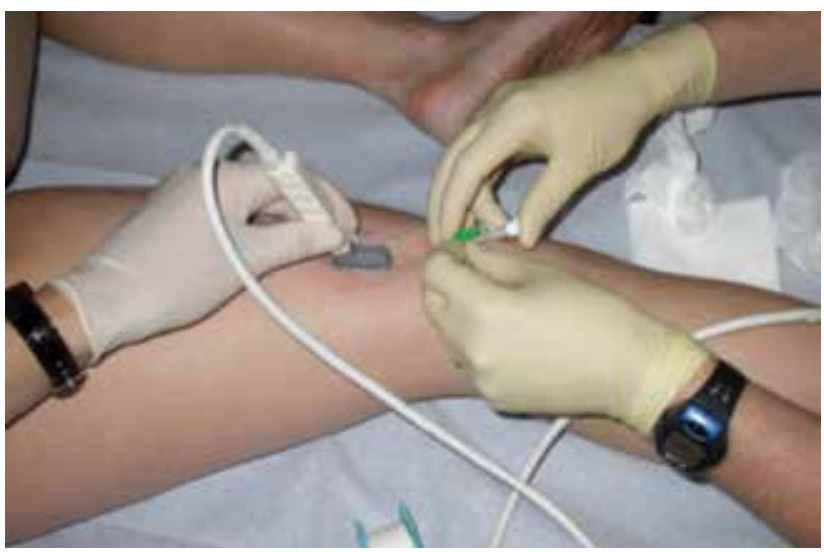

Figure 1:.Tessari method

method, ${ }^{8}$ which involves two 5 cc syringes being connected by a luer lock or three-way stopcock and being moved from side to side to side (Figure1).

\section{(a) sclerosant:air ratio}

The foam is prepared using $1 \mathrm{~mL}$ of sclerosant to 3 or $4 \mathrm{~mL}$ of air (1:4 or 1:5 ratio). ${ }^{9}$ More air leads to a smaller foam bubble, causing a more viscous foam. This results in greater effect of the blood column displacement and a longer contact with the endothelium. ${ }^{10} \mathrm{~A}$ large majority of the experts in the consensus meeting reported using a 1:4 liquid:air ratio, but the meeting decided to adopt the 1:5 ratio in the consensus statement in view of the abovementioned advantages. No studies have been published in which various liquid:air ratios were compared. The 1:5 ratio (1 part liquid to 4 parts air) has been included in the consensus statement as the standard recommendation.

\section{(b) Concentration-percentage of polidocanol}

Polidocanol percentages ranging from $1 \%$ to $3 \%$ are being used for the treatment of truncal varices. Two recent studies have compared the efficacy of $1 \%$ polidocanol and $3 \%$ polidocanol in the treatment of truncal varices of the great saphenous vein; they found no significant difference in efficacy. ${ }^{11,12}$ Ceulen et al. compared the two groups in terms of side-effects (thrombophlebitis, hyperpigmentation), and found that thrombophlebitis and hyperpigmentation were more frequently seen in the polidocanol $3 \%$ group.

These findings tie in with the clinical experiences reported by the experts attending the consensus meeting, a large majority of whom use polidocanol $1 \%$ foam. Both $1 \%$ and $3 \%$ polidocanol foam to treat truncal varices cause effective occlusion of the truncal varices. The meeting decided to include polidocanol $1 \%$ as the standard recommendation in the consensus statement, as this produces fewer side-effects like hyperpigmentation and phlebitis. 


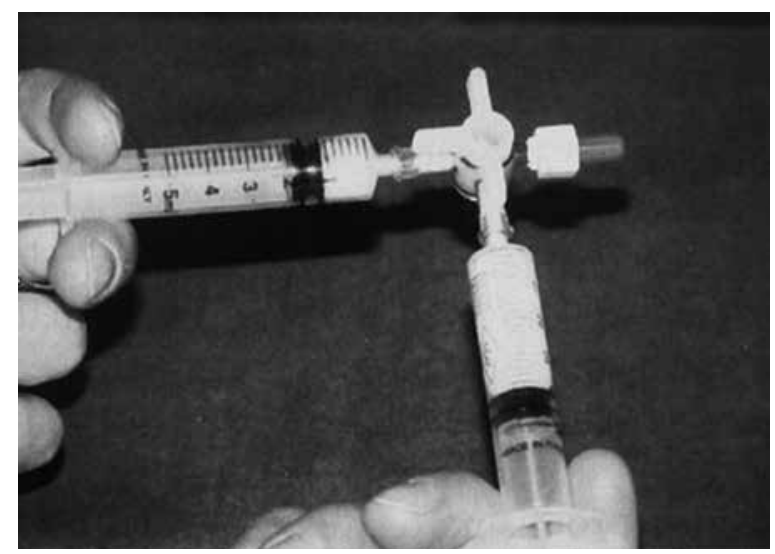

Figure 2. Puncturing the vein under duplex guidance

\section{Treatment}

This section describes the practical details of administering foam sclerotherapy. The Nederlands Tijdschrift voor Geneeskunde journal website features a video of the treatment.

\section{(a) Puncturing the vein}

The course of the vein (great / small saphenous vein) is marked out with the patient standing up, using duplex ultrasound guidance. With the patient in supine position, the vessel is punctured using a $21-G$ needle or an $18-G$ venflon. Using a venflon offers advantages to the less experienced physician, such as checking the intravascular placement of the needle and a reduced risk of perforating the vein. Injection is stopped when the foam has progressed to within a few centimetres from the junction.

\section{(b) Where should the vein be punctured?}

The great saphenous vein is usually punctured just above the knee, where the skin is strong and the varix is located superficially. If a different puncture site is chosen, this should be located at least $10 \mathrm{~cm}$ below the junction. ${ }^{9}$

All experts at the consensus meeting reported that they punctured the small saphenous vein as distally as possible.

The consensus recommendation is thus to puncture the great saphenous vein just above the knee and the small saphenous vein as distally as possible, observing a minimum distance of $10 \mathrm{~cm}$ below the junction. 


\section{(c) Volume injected per treatment}

Literature reports show that different volumes of foam are being injected per treatment, ranging from $6 \mathrm{~mL}$ to a maximum of $10 \mathrm{~mL} .9,13$ The Dutch specialists taking part in the consensus meeting also used different volumes per treatment, ranging from 2 to $10 \mathrm{~mL}$ for the great saphenous vein and from 1 to $4 \mathrm{~mL}$ for the small saphenous vein. The volume required can be minimized by waiting for vascular spasm to occur during the slow injection procedure. ${ }^{13}$ The vascular spasm is also an indication that the treatment has been successful.

The consensus statement recommends a maximum volume per treatment of $10 \mathrm{~mL}$ : Great saphenous vein: $2-10 \mathrm{~mL}$

Small saphenous vein: $1-5 \mathrm{~mL}$

Slow injection is preferred. The occurrence of a vascular spasm in the treated segment of the vein during the treatment signals the completion of the injection procedure.

\section{Aftercare}

\section{Compression therapy}

Doctors in the Netherlands as well as other countries generally apply compression therapy for about 4 to 6 weeks. ${ }^{14-16} \mathrm{~A}$ few studies have reported not using compression and still achieving effective occlusion of the vein. ${ }^{12}$ The consensus meeting preliminarily agreed on recommending 4 weeks of compression bandaging by means of a class II compression stocking, until new research has found more evidence that additional compression therapy offers no added value. Most of the specialists in the consensus group would also place a foampad or cotton wool bandage on the treated varix for 1 week, to add further pressure. Four weeks of compression therapy with a pelotte for additional local pressure in the first weeks was considered sufficient.

\section{Contraindications}

The use of foam sclerotherapy is subject to the same contraindications as fluid sclerotherapy (Table 1).

Table 1. Contraindications for sclerotherapy

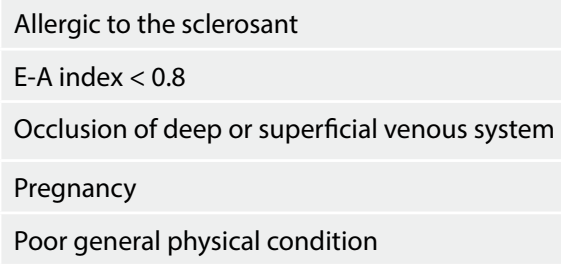




\section{Conclusion}

Foam sclerotherapy is an effective and minimally invasive intervention, offering effective treatment of truncal varices. The advantage of this treatment is that it does not require any anaesthesia and that patients can generally resume their normal activities soon. It is our expectation that foam sclerotherapy will become a much-used treatment for truncal varices in the future.

Our intention in producing this consensus statement (Table 2) was to inform interested general practitioners of the existence of this minimally invasive technique and to offer specialists guidelines for the treatment of truncal varices by foam sclerotherapy. Standardized application of the technique may optimize the results achieved.

Table 2. Summary of foam sclerotherapy consensus statement

\section{Summary of foam sclerotherapy consensus}

1 Foam sclerotherapy is an effective treatment for varices, especially truncal varices.

2 Foam should be prepared by the Tessari method.

3 Foam should be prepared using $1 \mathrm{ml}$ sclerosant to $4 \mathrm{ml}$ air.

4 Polidocanol $1 \%$ should be used for the treatment of truncal varices.

5 Puncturing the vein using a venflon is recommended.

6 The great saphenous vein should be punctured just above the knee, the small saphenous vein as distally as possible.

7 A minimal distance of $10 \mathrm{~cm}$ should be maintained between the injection site and the junction.

8 A maximum of $10 \mathrm{~mL}$ foam should be used per treatment.

9 A slow injection procedure should be used.

10 Treatment should be followed by 4 weeks of compression therapy.

11 Contraindications are the same as those for fluid sclerotherapy.

\section{Acknowledgements}

We would like to thank those participating in the consensus meeting for their contributions to this consensus statement: R. Ceulen, MD, PhD, R. Damstra MD, PhD, G. Davies, MD, A. Van Geest, MD, J. Van der Kley, MD, M. Kockaert, MD, L.Schultze Kool,Professor, MD, PhD, R. Krijnen, MD, PhD, M. Maessen-Visch, MD, PhD, P. Van Neer, MD, Phd, K.P. De Roos, MD, Phd, C. Van der Vleuten MD, PhD, V. Van der Wal, MD. 


\section{References}

1. Meissner MH, Gloviczki P, Bergan J, Kistner RL, Morrison N, Pannier F, et al. Primary chronic venous disorders. J Vasc Surg. 2007;46 Suppl S:54S-67S.

2. Evans $C J$, Fowkes FG, Ruckley CV, Lee AJ. Prevalence of varicose veins and chronic venous insufficiency in men and women in the general population: Edinburgh Vein Study. J Epidemiol Community Health. 1999;53:149-53.

3. Jia X, Mowatt G, Burr JM, Cassar K, Cook J, Fraser C. Systematic review of foam sclerotherapy for varicose veins. Br J Surg. 2007;94:925-36.

4. Bountouroglou DG, Azzam M, Kakkos SK, Pathmarajah M, Young P, Geroulakos G. Ultrasound-guided foam sclerotherapy combined with sapheno-femoral ligation compared to surgical treatment of varicose veins: early results of a randomised controlled trial. Eur J Vasc Endovasc Surg. 2006;31:93-100.

5. O'Hare JL, Earnshaw JJ. The use of foam sclerotherapy for varicose veins: a survey of the members of the Vascular Society of Great Britain and Ireland. Eur J Vasc Endovasc Surg. 2007;34:232-5.

6. Kockaert MA, de Roos KP, Neumann HA. Echo-guided compression sclerotherapy using foam: an improvement in the treatment of varicose veins. Ned Tijdschr Geneeskd. 2006;150:1758-63.

7. Kern P. Sclerotherapy of varicose leg veins. Technique, indications and complications. Int Angiol. 2002;21:40-5.

8. Tessari L, Cavezzi A, Frullini A. Preliminary experience with a new sclerosing foam in the treatment of varicose veins. Dermatol Surg. 2001;27:58-60.

9. Breu FX, Guggenbichler S. European Consensus Meeting on Foam Sclerotherapy, April, 4-6, 2003, Tegernsee, Germany. Dermatol Surg. 2004;30:709-17; discussion 17.

10. Wollmann JC. The history of sclerosing foams. Dermatol Surg. 2004;30:694-703; discussion

11. Ceulen RP, Bullens-Goessens YI, Pi-Van de Venne SJ, Nelemans PJ, Veraart JC, Sommer A. Outcomes and side effects of duplex-guided sclerotherapy in the treatment of great saphenous veins with $1 \%$ versus $3 \%$ polidocanol foam: results of a randomized controlled trial with 1-year follow-up. Dermatol Surg. 2007;33:276-81

12. Hamel-Desnos C, Ouvry P, Benigni JP, Boitelle G, Schadeck M, Desnos P, et al. Comparison of $1 \%$ and $3 \%$ polidocanol foam in ultrasound guided sclerotherapy of the great saphenous vein: a randomised, double-blind trial with 2 year-follow-up. "The 3/1 Study". Eur J Vasc Endovasc Surg. 2007;34:723-9; discussion 30 .

13. Hamel-Desnos C, Guias B, Jousse S, Desnos P, Bressollette L. Foam echosclerotherapy by puncture-direct injection: technique and quantities. J Mal Vasc. 2006;31:180-9.

14. Partsch H, Baccaglini U, Stemmer R. Questionaire on sclerotherapy. Phlebology. 1997;12:43-55.

15. Rabe E, Otto J, Schliephake D, Pannier F. Efficacy and Safety of Great Saphenous Vein Sclerotherapy Using Standardised Polidocanol Foam (ESAF): A Randomised Controlled Multicentre Clinical Trial. Eur J Vasc Endovasc Surg. 2007.

16. Gibson KD, Ferris BL, Pepper D. Foam sclerotherapy for the treatment of superficial venous insufficiency. Surg Clin North Am. 2007;87:1285-95, xii-xiii. 


Chapter 3

\section{Randomized clinical trial of ultrasound- guided foam sclerotherapy versus surgery for the incompetent great saphenous vein}

N. Shadid, R. Ceulen, P. Nelemans, C. Dirksen, J. Veraart, G. W. Schurink, P. van Neer, J. vd Kley, E. de Haan and A. Sommer

Br J Surg. 2012 Aug;99(8):1062-70. 


\section{Abstract}

Background: New minimally invasive treatment modalities, such as ultrasound-guided foam sclerotherapy (UGFS), are becoming more popular. In a multicentre randomized controlled non-inferiority trial, the effectiveness and costs of UGFS and surgery for treatment of the incompetent great saphenous vein (GSV) were compared.

Methods: Patients with primary great saphenous varicose veins were assigned randomly to either UGFS or surgical stripping with high ligation. Recurrence, defined as reflux combined with venous symptoms, was determined on colour duplex scans at baseline, 3 months, 1 year and 2 years after initial treatment. Secondary outcomes were presence of recurrent reflux (irrespective of symptoms), reduction of symptoms, health-related quality of life (EQ$\left.5 D^{\mathrm{TM}}\right)$, adverse events and direct hospital costs.

Results: Two hundred and thirty patients were treated by UGFS and 200 underwent GSV stripping. The 2-year probability of recurrence was similar in the UGFS and surgery groups: 11.3 per cent ( 24 of 213 ) and 9.0 per cent (16 of 177) respectively $(P=0.407)$. At 2 years, reflux irrespective of venous symptoms was significantly more frequent in the UGFS group (35.0 per cent) than in the surgery group (21.0 per cent) $(P=0.003)$. Mean(s.d.) hospital costs per patient over 2 years were $€ 774(344)$ per patient for UGFS and $€ 1824(141)$ for stripping.

Conclusion: At 2-year follow-up, UGFS was not inferior to surgery when reflux associated with venous symptoms was the clinical outcome of interest. UGFS has the potential to be a cost-effective approach to a common health problem. Registration numbers: NCT01103258 (http://www.clinicaltrials.gov) and NTR654 (http://www.trialregister.nl). 


\section{Introduction}

Lower-extremity venous insufficiency is a common health problem in Western countries, and its prevalence increases with age. Epidemiological studies show that a quarter of the adult population have varicose veins ${ }^{1}$. This condition is often associated with great saphenous vein (GSV) reflux ${ }^{1-3}$. The disease has a substantial impact on quality of life, as well as on the resources and budgets of healthcare systems ${ }^{2}$. For many years, the standard treatment was surgical stripping of the GSV. Research comparing liquid sclerotherapy and surgery for the treatment of GSV incompetence showed that surgery was more effective ${ }^{3,4}$. Long-term results of surgery indicated recurrence rates of between 21 and 26 per cent after 3 years of follow-up and 60 per cent after 34 years ${ }^{5-7}$. However, in recent years there has been an increased demand for minimally invasive and less expensive procedures such as ultrasound-guided foam sclerotherapy (UGFS), endovenous laser ablation (EVLA) and radiofrequency ablation (RFA) ${ }^{8}$. UGFS is a variant of liquid sclerotherapy, in which the liquidair mixture (foam) is injected into varicose veins under ultrasound guidance. Compared with liquid sclerotherapy, UGFS is more effective ${ }^{9,10}$. UGFS has a reported success rate of 75-85 per cent after 1 year and 69 per cent after 2 years of follow-up ${ }^{11-13}$. Advantages of this treatment are that it is less invasive, reduces healthcare costs, and is associated with a shorter recovery time than surgery ${ }^{14-16}$, making UGFS an attractive alternative to surgery for the treatment of varicose veins.

The aim of the present multicentre randomized clinical trial was to compare the effectiveness and hospital costs of UGFS with those of surgery in treatment of the incompetent GSV. Although success rates after one UGFS session may be lower than after surgery, UGFS can be a cost-effective alternative to surgery because of the easy and relatively low cost of retreatment.

\section{Methods}

Consecutive patients referred for treatment of symptomatic varicose veins by general practitioners were recruited at the outpatient dermatology and surgery departments of three hospitals in the Netherlands: Maastricht University Medical Centre, Atrium Medical Centre Heerlen and Laurentius Hospital Roermond.

Screening assessments included medical history, clinical examination and duplex imaging. Patients with a primary GSV incompetence were eligible; inclusion criteria were the presence of one or more venous symptoms, in combination with incompetence of the saphenofemoral junction and GSV (measured over a distance of at least $20 \mathrm{~cm}$ in the upper leg) and a reflux time of more than $0.5 \mathrm{~s}$, and a normal deep venous system on duplex 
imaging. Patients with an incompetent deep venous system, signs of a previous deep venous thrombosis on duplex imaging, an active ulcer or a contraindication to the use of polidocanol were excluded.

The trial was approved by the medical ethics committee of Maastricht University Medical Centre. All patients provided written informed consent before participating in the study, according to the principles of the Declaration of Helsinki.

\section{Randomization}

Eligible patients with primary incompetence of the GSV were included and assigned randomly to UGFS or surgery using a computer-generated randomization scheme with random permuted blocks of eight.

\section{Outcome measures}

The primary outcome measure of this study was the cumulative probability of recurrent varicose veins 2 years after treatment. Recurrence of varicose veins was defined as the presence of one or more venous symptoms such as pain, cramps, restless legs and a tired/heavy feeling in the treated leg, in combination with the presence of reflux longer than $0.5 \mathrm{~s}$. This primary outcome measure was chosen for pragmatic reasons, because in clinical practice only patients with both venous reflux and symptoms are candidates for retreatment. Recurrent reflux was defined as reflux for more than $2 \mathrm{~cm}$ in length in the treated vein segment (proximal GSV) as measured by colour flow Doppler ultrasonography. Duplex findings of the treated proximal GSV were categorized as: 1 absence of reflux; 2, reflux; 3, occlusion; 4, partial occlusion with reflux; 5 , absence of vein. Patients in categories 2 and 4 were considered to have reflux. Duplex findings in the distal GSV and other veins were also recorded.

Secondary outcomes were presence of recurrent reflux (irrespective of symptoms), reduction of symptoms, health-related quality of life (EQ-5D ${ }^{\mathrm{TM}}$; EuroQol Group, Rotterdam, The Netherlands), adverse events and direct hospital costs.

Outcomes were evaluated at baseline, 3 months, 1 year and 2 years after treatment. Patients were asked about the presence of venous complaints such as pain, cramps, tired/heavy feeling and restless legs. The frequency of symptoms was classified into four categories: 1, absent; 2, occasional; 3, frequent; 4, continuous. Patients were also asked to indicate whether the treatment met their expectations in terms of aesthetic and functional outcome (reduced symptoms), with the following answer options: 1, not meeting expectations; 2, partially meeting expectations; 3 , fully meeting expectations. A Clinical Etiologic Anatomic 
Pathophysiologic (CEAP) classification was performed; all varicose veins were mapped and a Venous Clinical Severity Score (VCSS) was assigned by the research physician.

Patients' health-related quality of life was measured by means of the EQ-5D ${ }^{\mathrm{TM}}$. EQ-5D ${ }^{\mathrm{TM}}$ consists of five dimensions (mobility, self-care, usual activities, pain and mood), each of which is rated at three levels (no problems, some problems, severe problems), yielding 243 potential combinations of health states. Each health state is associated with a utility score by means of an additive function derived from the Dutch general population ${ }^{17(1)}$. Furthermore, EQ-5D ${ }^{\mathrm{TM}}$ consists of a visual analogue scale (VAS) on which patients can rate their health state from worst possible (0) to best possible (100).

\section{Colour duplex imaging}

Duplex examination was performed at baseline, 3 months, 1 year and 2 years after treatment by an independent ultrasound technician using a colour duplex scanner (MyLab25 ${ }^{\mathrm{TM}}$; Esaote Benelux, Maastricht, The Netherlands) with a 10-MHz transducer to detect venous reflux in the GSV and perform venous mapping of the entire deep and superficial venous system. Duration of reflux in the GSV was measured by colour-flow Doppler ultrasonography. Treated veins were screened for venous occlusion, flow and compressibility.

\section{Ultrasound-guided foam sclerotherapy}

The GSV was identified by duplex imaging in the standing position and marked from the groin following the path of reflux in the GSV. Sclerosing foam was prepared with the doublesyringe technique, applying a $1: 4$ ratio of sclerosant : air. One syringe was filled with $1 \mathrm{ml}$ 3 per cent polidocanol (Aethoxysklerol'; Kreussler Pharma, Wiesbaden, Germany) and the other syringe with $4 \mathrm{ml}$ air. Patients were treated in supine position with an 18-Fr intravenous cannula (B. Braun, Melsungen, Germany), which was inserted just above the knee. The treatment was considered successful when the proximal GSV was completely filled with foam and maximal venospasm was achieved. The majority of patients received an injection of $5 \mathrm{ml}$ or more; 48 patients received less than $5 \mathrm{ml}$. Elevation of the leg or compression of the saphenofemoral junction was not used. Compression was applied with a foam pad over the treated area and an antiembolism stocking (Brevet TX $10 \mathrm{mmHg}$; Mölnlycke Health Care Benelux, Breda, The Netherlands) for 1 week, day and night. A class II elastic stocking (Mediven Plus 23 mmHg; Medi, Bayreuth, Germany) was prescribed during the day for 6 weeks. After treatment, patients were instructed to walk for at least $30 \mathrm{~min}$, after which they could resume their usual daily activities. If necessary, patients received additional treatment at the subsequent visits for other varicose veins with UGFS or phlebectomy. 


\section{Surgery}

The surgery was done as a day-case procedure under general or spinal anaesthesia. A groin incision was carried out and the saphenofemoral junction dissected. After ligating side branches of the GSV, the saphenofemoral junction was ligated and the GSV divided and stripped to just below the knee using a stripper (Multistrip ${ }^{\mathrm{TM}}$; Prodimed, Neuilly en Thelle, France). The incision in the groin was closed with 3-0 polyglactin 910 subcutaneously and with 4-0 poliglecaprone 25 intracutaneously. The decision to perform phlebectomies was left to the surgeon. The leg was bandaged from distal to proximal. After surgery, the patient was mobilized immediately. After $48 \mathrm{~h}$, the bandages were replaced by a class II elastic stocking (Mediven Plus $23 \mathrm{mmHg}$ ) for 6 weeks. Patients were advised to resume their usual daily routine after 1 week.

\section{Cost analysis}

The cost analysis was performed from a hospital perspective with a 2-year time horizon. Data regarding resource use were obtained for each patient from case report forms. Cost data included costs of outpatient visits, study treatment (UGFS or stripping), retreatment, and complementary treatment of the GSV and other varicose veins during follow-up. Unit prices, comprising personnel, materials, capacity and overhead costs, were obtained from the finance department of Maastricht University Medical Centre. All prices were expressed in 2008 euros. Hospital costs over 2 years were calculated by multiplying resource use by cost price per unit of resource use. Costs occurring after 1 year were discounted.

\section{Statistical analysis}

The study was designed as a non-inferiority trial. Based on literature data, the 2-year probability of recurrent varicose veins after standard treatment by surgery was assumed as 30 per cent. Power calculation showed that a total sample size of 460 patients was required to detect a 10 per cent difference in failure rate between surgery and UGFS with a power of 80 per cent (one-sided type I error of 0.05 ).

Differences between treatment groups in the proportions of patients with a specific outcome at 3 months, 1 year and 2 years after treatment were tested for statistical significance using the $X^{2}$ test. Ninety-five per cent confidence intervals (c.i.) around the difference in proportions were calculated ${ }^{18} . P<0.050$ was considered to indicate statistical significance. Only patients who underwent the allocated intervention were included in the analysis. All data were analysed with SPSS $^{\circ}$ version 16.0 (SPSS, Chicago, Illinois, USA) and Stata version 11.1 (SAS Institute, Cary, North Carolina, USA). 


\section{Results}

From October 2005 to December 2007, 530 patients were eligible for the study. Seventy patients were excluded and 55 with an incompetent GSV declined to participate, usually because they had a preference for one of the two treatments. Finally, 460 patients with primary incompetence of the GSV were randomized (Fig. 1). Of the 233 patients assigned to UGFS, 230 were treated by this modality; three patients withdrew from the study after randomization. Of the 227 patients assigned to surgery, 200 were treated and 27 withdrew from the study, 24 of whom declined surgical treatment.

Baseline data were available for 460 patients. According to the CEAP classification, assessed by the coordinating researcher, all patients had C2-C5EpAsPr disease. Complete followup data for up to 2 years after treatment were obtained for 213 (92.6 per cent) of the 230 patients in the UGFS group and for 177 ( 88.5 per cent) of the 200 patients having surgery (Fig. 1). Table 1 shows the baseline characteristics of the 460 enrolled participants, and of the 430 who underwent the assigned treatment. Baseline characteristics were similar in the two groups. VAS values at baseline were lacking for 50 (11.6 per cent) of the 430 treated patients owing to logistical problems.

Table 1. Baseline characteristics of randomized and treated patients assigned to ultrasound-guided foam sclerotherapy or surgery.

\begin{tabular}{|c|c|c|c|c|}
\hline & \multicolumn{2}{|c|}{ Randomized patients $(n=460)$} & \multicolumn{2}{|c|}{ Treated patients $(n=430)$} \\
\hline & UGFS ( $n=233)$ & Surgery $(n=227)$ & UGFS ( $n=230)$ & Surgery $(n=200)$ \\
\hline Age (years)* & $55.8(13.4)(27-87)$ & $54.6(13.4)(24-86)$ & $51.6(13.3)(22-83)$ & $50.7(13.4)(20-81)$ \\
\hline Sex ratio $(F: M)$ & $175: 58$ & $162: 65$ & $173: 57$ & $141: 59$ \\
\hline \multicolumn{5}{|l|}{ Clinical presentation $\dagger$} \\
\hline C2 (varicose veins) & $191(82.0)$ & $181(79.7)$ & $188(81.7)$ & $156(78.0)$ \\
\hline C3 (veins with oedema) & $18(7.7)$ & $23(10.1)$ & $18(7.8)$ & $23(11.5)$ \\
\hline C4 (skin change) & $19(8.2)$ & $17(7.5)$ & $19(8.3)$ & $15(7.5)$ \\
\hline C5 (healed ulcer) & $5(2.1)$ & $6(2.6)$ & $5(2.2)$ & $6(3.0)$ \\
\hline \multicolumn{5}{|l|}{ GSV diameter $(\mathrm{mm})^{*}$} \\
\hline Upper thigh & $6.1(2.0)(2.3-15.4)$ & $6.6(2.4)(2.2-18.6)$ & $6.1(2.0)(2.3-15.4)$ & $6.8(2.4)(2.2-18.6)$ \\
\hline Mid thigh & $5.5(1.8)(1.5-13.6)$ & $5.8(2.0)(2.3-12.0)$ & $5.5(1.8)(1.5-13.6)$ & $5.9(2.0)(2.3-12.0)$ \\
\hline Lower thigh & $5.2(1.9)(1.2-12.8)$ & $5.5(2.0)(1.4-15.0)$ & $5.2(1.9)(1.2-12.8)$ & $5.7(2.0)(1.4-15.0)$ \\
\hline Duration of GSV reflux (s)* & $2.4(1.6)(0.5-8.0)$ & $2.5(1.7)(0.5-9.0)$ & $2.4(1.6)(0.5-8.0)$ & $2.6(1.9)(0.6-9.0)$ \\
\hline Volume of foam $(\mathrm{ml})^{*}$ & $? ? ?$ & - & $5.4(2.0)(2-20)$ & - \\
\hline
\end{tabular}




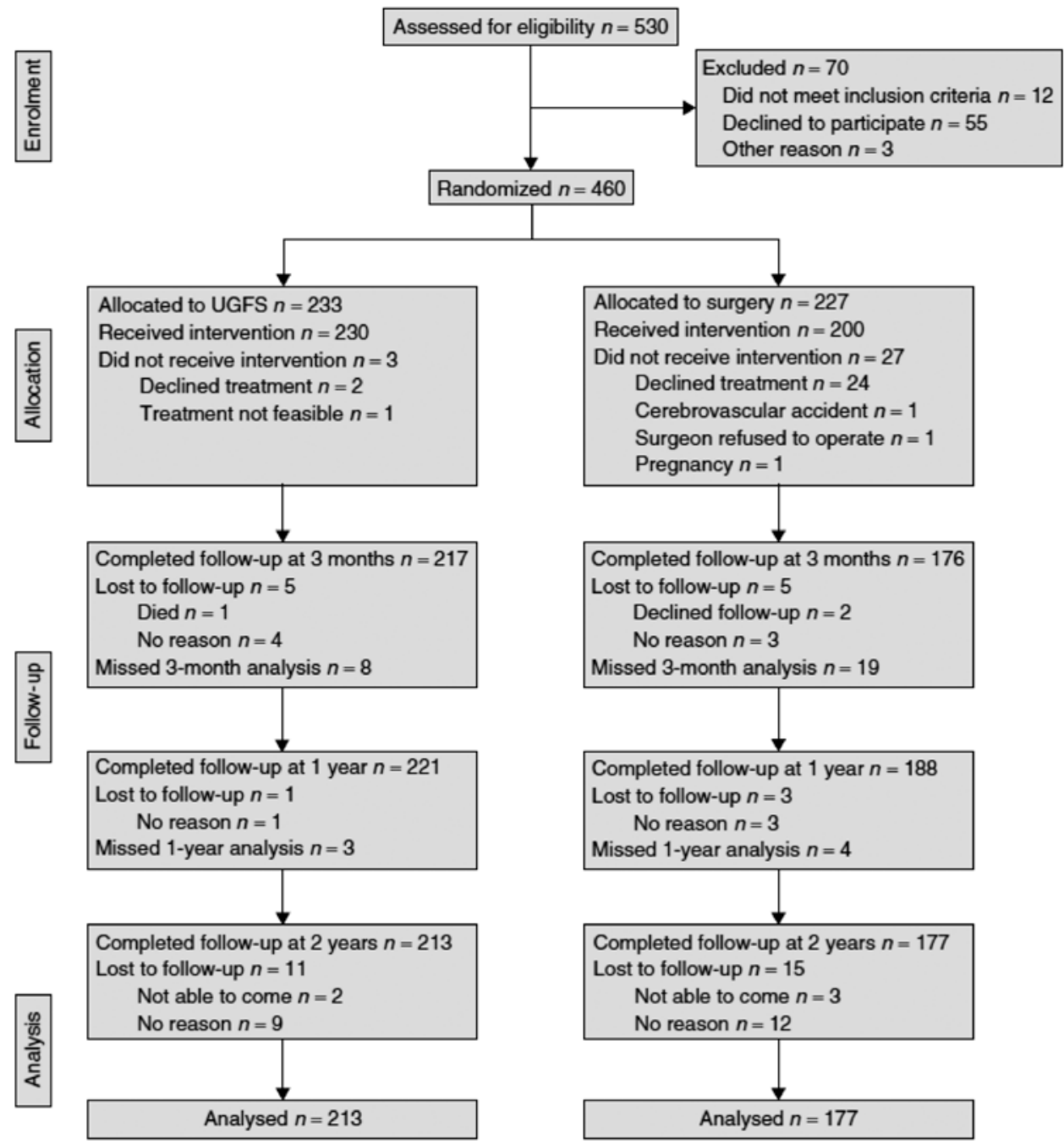

Figure 1. CONSORT diagram for the trial. UGFS, ultrasound-guided foam sclerotherapy

Two years after treatment the probability of recurrence in the UGFS group was 11.3 per cent ( 24 of 213$)$, compared with 9.0 per cent (16 of 177$)$ in the surgery group $(P=0.407)$ (Fig. 2a). The difference in proportions was 2.3 (95 per cent c.i. -4.3 to 8.1) per cent. During follow-up, differences between the treatments emerged with respect to anatomical results (presence of reflux irrespective of venous complaints). Although there were no significant differences at 3 months and 1 year after treatment, the proportion of patients with reflux irrespective of venous symptoms 2 years after treatment was significantly higher following UGFS than for surgery: 35.0 and 21.0 per cent respectively, difference 14.0 (4.4 to 22.5) per 
cent ( $P=0.003$ ) (Fig. 2b). However, the percentage with reflux in the surgery group may have been underestimated, because in this group nine of ten patients with reflux at 1 year did not attend the final consultation at 2 years, compared with only one patient in the UGFS group. Assuming that recurrent varicosities in these patients were still present at 2 years, the proportion of patients with reflux would be 35.0 and 24.7 per cent in the UGFS and surgery group respectively: difference 10.3 (0.8 to 19.3$)$ per cent $(P=0.025)$.

Reflux in the distal GSV below the knee at 2 years was present in 41.3 and 42.9 per cent respectively of patients in the UGFS and surgery groups $(P=0.746)$

Of the 230 patients treated with foam sclerotherapy, 61 patients had additional treatment. Two patients had UGFS of the small saphenous vein (SSV) and 14 of a tributary of the

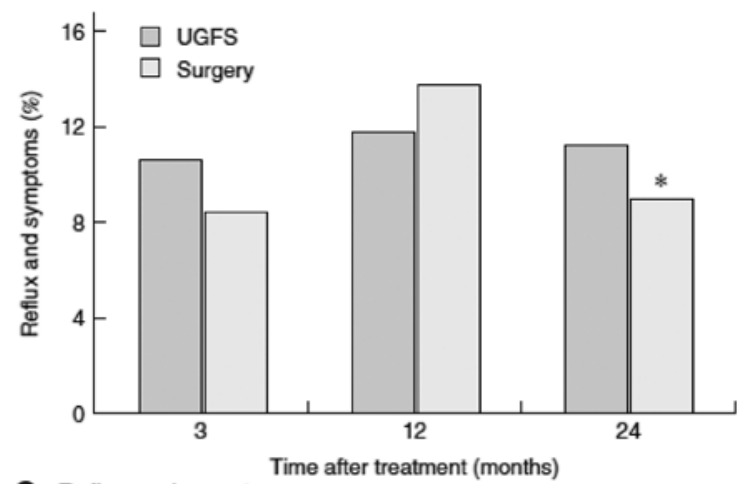

a Reflux and symptoms

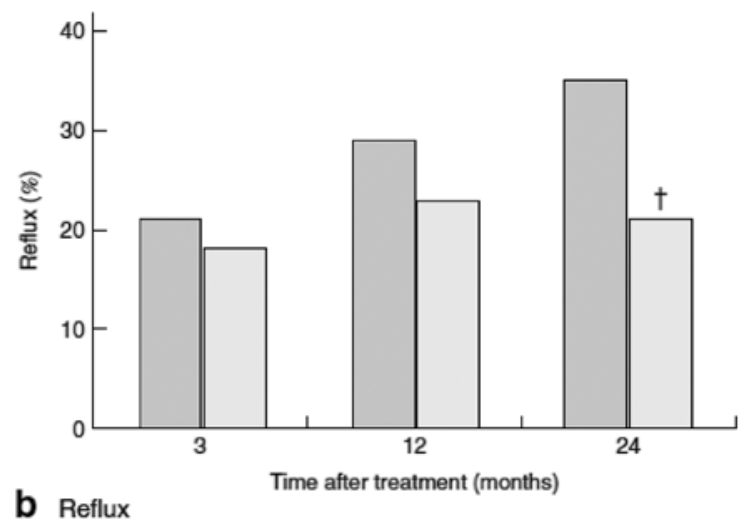

Figure 2. Percentage of patients with reflux $a$ in combination with venous symptoms and $b$ irrespective of venous symptoms at 3,12 and 24 months of follow-up following ultrasound-guided foam sclerotherapy (UGFS) or surgery. * $P=0.407$ and $+P=0.003$ versus UGFS ( $X 2$ test). 
GSV, 26 patients had phlebectomy of a tributary of the GSV and 19 had sclerotherapy of telangiectatic veins. In the surgery group, phlebectomy was done in 87 (43.5 per cent) of 200 stripping procedures. At subsequent visits, 28 patients had an additional treatment; one patient had UGFS of the SSV, seven patients had phlebectomy of a tributary of the GSV, four were treated by foam sclerotherapy of a tributary and 16 patients had sclerotherapy for telangiectatic veins.

\section{Symptom scores}

At 2 years the mean change in the VCSS from baseline was similar in the two groups: -1.49 in the UGFS group versus -1.75 in the surgery group $(P=0.232)$. Change in health-related quality of life did not vary between groups. The mean change in the EQ-5D ${ }^{\mathrm{TM}}$ utility score (score at 2 years of follow-up minus score at baseline) was 0.064 and 0.061 in the UGFS and surgery groups respectively $(P=0.889)$. The mean changes for the VAS scores were -0.36 in the UGFS and -1.8 in the surgery group $(P=0.577)$. After 2 years, no significant differences in symptom relief were observed between treatment groups. The greatest impact of both treatments was observed on cramps and heavy or tired feeling, whereas pain and restless legs were less affected by treatment (Table 2). Complete satisfaction with the reduction of venous complaints was reported by 59.6 per cent of patients in the UGFS group and 66.1 per cent of those having surgery $(P=0.207)$.

\section{Retreatment}

Of the 230 patients in the UGFS group, 190 (82.6 per cent) had only one treatment session. Forty patients had a repeat session with UGFS, five of whom had more than two sessions. Two patients in the surgery group had re-exploration of the groin. Eight patients were referred for UGFS by their surgeon because reoperation was technically difficult. In both treatment groups, some patients with recurrence were not retreated because they considered their symptoms not serious enough, or the surgeon recommended conservative treatment with elastic stockings.

\section{Adverse events}

Thrombophlebitis as an adverse event of UGFS occurred in 17 (7.4 per cent) of the 227 patients (Table 3). Seven patients required non-steroidal anti-inflammatory drugs (diclofenac $50 \mathrm{mg}$ three times daily) and compression. After surgery, four patients developed a groin infection, two of which required surgical evacuation. Paraesthesia after surgery persisted in six patients, who experienced numbness in the upper or lower leg, although no severe nerve injuries were seen. Within 1 week after treatment, two patients in the UGFS group experienced a serious adverse event: one patient had a deep venous thrombosis and the other had a pulmonary embolus. Both patients were treated according to protocol with oral anticoagulant therapy. 
Table 2: Effect of ultrasound-guided foam sclerotherapy and surgery on venous symptoms and patient satisfaction of patients with aesthetic and functional outcomes at 3,12 and 24 months

\begin{tabular}{|c|c|c|c|c|c|c|c|c|c|}
\hline & \multicolumn{3}{|c|}{3 months } & \multicolumn{3}{|c|}{12 months } & \multicolumn{3}{|c|}{24 months } \\
\hline & $\begin{array}{l}\text { UGFS } \\
(n=217)\end{array}$ & $\begin{array}{l}\text { Surgery } \\
(n=176)\end{array}$ & $P^{*}$ & $\begin{array}{l}\text { UGFS } \\
(n=221)\end{array}$ & $\begin{array}{l}\text { Surgery } \\
(n=188)\end{array}$ & $P^{*}$ & $\begin{array}{l}\text { UGFS } \\
(n=213)\end{array}$ & $\begin{array}{l}\text { Surgery } \\
(n=177)\end{array}$ & $P^{*}$ \\
\hline \multicolumn{10}{|c|}{ Venous symptoms } \\
\hline \multicolumn{3}{|l|}{ Pain } & 0.792 & & & 0.833 & & & 0.340 \\
\hline More & $12(5.5)$ & $10(5.7)$ & & $20(9.0)$ & $14(7.4)$ & & $14(6.6)$ & $6(3.4)$ & \\
\hline Stable & $111(51.2)$ & $84(47.7)$ & & $109(49.3)$ & $93(49.5)$ & & $104(48.8)$ & $86(48.6)$ & \\
\hline Less & $94(43.3)$ & $82(46.6)$ & & $92(41.6)$ & $81(43.1)$ & & 95 (44.6) & $85(48.0)$ & \\
\hline \multicolumn{3}{|c|}{ Tired/heavy feeling } & 0.273 & & & 0.287 & & & 0.454 \\
\hline More & $8(3.7)$ & $2(1.1)$ & & $5(2.3)$ & $9(4.8)$ & & $6(2.8)$ & $5(2.8)$ & \\
\hline Stable & $71(32.7)$ & $61(34.7)$ & & $85(38.5)$ & $64(34.0)$ & & $74(34.7)$ & $51(28.8)$ & \\
\hline Less & 138 (63.6) & $113(64.2)$ & & $131(59.3)$ & 115 (61.2) & & $133(62.4)$ & $121(68.4)$ & \\
\hline \multicolumn{3}{|l|}{ Cramps } & 0.641 & & & 0.748 & & & 0.364 \\
\hline More & $9(4.1)$ & $6(3.4)$ & & $10(4.5)$ & $9(4.8)$ & & $8(3.8)$ & $8(4.5)$ & \\
\hline Stable & $79(36.4)$ & $72(40.9)$ & & $84(38.0)$ & $78(41.5)$ & & $79(37.1)$ & $77(43.5)$ & \\
\hline Less & $129(59.4)$ & $98(55.7)$ & & $127(57.5)$ & $101(53.7)$ & & $126(59.2)$ & $92(52.0)$ & \\
\hline \multicolumn{3}{|l|}{ Restless legs } & 0.525 & & & 0.867 & & & 0.865 \\
\hline More & $27(12.4)$ & $16(9.1)$ & & $34(15.4)$ & $26(13.8)$ & & $29(13.6)$ & $21(11.9)$ & \\
\hline Stable & $153(70.5)$ & 126 (71.6) & & 150 (67.9) & $132(70.2)$ & & 145 (68.1) & $124(70.1)$ & \\
\hline Less & $37(17.1)$ & 34 (19.3) & & 37 (16.7) & $30(16.0)$ & & 39 (18.3) & $32(18.1)$ & \\
\hline \multicolumn{10}{|c|}{ Patient satisfaction } \\
\hline \multicolumn{3}{|l|}{ Aesthetic } & 0.134 & & & 0.763 & & & 0.029 \\
\hline $\begin{array}{l}\text { Not } \\
\text { satisfied }\end{array}$ & 39 (18.0) & 19 (10.8) & & 33 (14.9) & $32(17.0)$ & & 31 (14.6) & $23(13.0)$ & \\
\hline $\begin{array}{l}\text { Reasonably } \\
\text { satisfied }\end{array}$ & $95(43.8)$ & 82 (46.6) & & $89(40.3)$ & 70 (37.2) & & 97 (45.5) & 60 (33.9) & \\
\hline $\begin{array}{l}\text { Fully } \\
\text { satisfied }\end{array}$ & $83(38.2)$ & 75 (42.6) & & $99(44.8)$ & $86(45.7)$ & & 85 (39.9) & $94(53.1)$ & \\
\hline \multicolumn{3}{|l|}{ Functional } & 0.058 & & & 0.095 & & & 0.207 \\
\hline $\begin{array}{l}\text { Not } \\
\text { satisfied }\end{array}$ & $20(9.2)$ & $15(8.5)$ & & $22(10.0)$ & $28(14.9)$ & & $17(8.0)$ & $17(9.6)$ & \\
\hline $\begin{array}{l}\text { Reasonably } \\
\text { satisfied }\end{array}$ & $76(35.0)$ & $43(24.4)$ & & 70 (31.7) & 44 (23.4) & & $69(32.4)$ & $43(24.3)$ & \\
\hline $\begin{array}{l}\text { Fully } \\
\text { satisfied }\end{array}$ & $121(55.8)$ & $118(67.0)$ & & $129(58.4)$ & $116(61.7)$ & & 127 (59.6) & $117(66.1)$ & \\
\hline
\end{tabular}

Values in parentheses are percentages. UGFS, ultrasound-guided foam sclerotherapy. ${ }^{*}{ }^{2}$ test. 
Table 3. Complications and side-effects after treatment of the incompetent great saphenous vein with ultrasoundguided foam sclerotherapy or surgery.

\begin{tabular}{|l|l|l|l|}
\hline & UGFS & Surgery & P* \\
\hline Early complications (within 1 week) & $n=230$ & $n=200$ & 0.031 \\
\hline Groin infection & $0(0)$ & $4(2.0)$ & 0.062 \\
\hline Haematoma & $0(0)$ & $3(1.5)$ & 0.008 \\
\hline Paraesthesia & $0(0)$ & $6(3.0)$ & 0.021 \\
\hline Pain at injection site & $6(2.6)$ & $0(0)$ & $<0.001$ \\
\hline Thrombophlebitis & $17(7.4)$ & $0(0)$ & 0.105 \\
\hline Headache/migraine & $3(1.3)$ & $0(0)$ & 0.351 \\
\hline Deep venous thrombosis & $1(0.4)$ & $0(0)$ & 0.351 \\
\hline Pulmonary embolism & $1(0.4)$ & $0(0)$ & $n=177$ \\
\hline Late complications (at 2 years) & $n=213$ & $2(1.1)$ & 0.017 \\
\hline Hyperpigmentation & $12(5.6)$ & $2(1.1)$ & 0.242 \\
\hline Telangiectatic matting & $6(2.8)$ & \\
\hline
\end{tabular}

Values in parentheses are percentages. UGFS, ultrasound-guided foam sclerotherapy. ${ }^{*}{ }^{2}$ test.

\section{Costs}

The cost analysis showed mean total hospital costs per patient of $€ 774$ for UGFS and $€ 1824$ for surgery (Table 4). The difference was mainly due to the costs of treatment and preceding visits to outpatients, which totalled $€ 343$ per patient for UGFS and $€ 1504$ for surgery. Costs of retreatment and complications were slightly higher for UGFS. Although complications were recorded in the case report form, the consequences in terms of hospital resource use were not, so these costs were estimated. Thrombophlebitis was assumed to require two outpatient visits and 1 week of diclofenac treatment ( $€ 0.56$ per day). Patients with a groin infection were assumed to visit the outpatient department two times ( 3 times for those needing surgical evacuation) and to require 1 week of flucloxacillin ( $€ 2.82$ per day). The costs of deep venous thrombosis and pulmonary embolism were based on a paper by ten Cate-Hoek et al. ${ }^{19}$.

\section{Discussion}

The principal finding of this randomized clinical trial with a 2-year follow-up was that UGFS was not inferior to surgery when reflux associated with venous symptoms was considered the clinical outcome of interest. The combination of reflux and venous symptoms was chosen, because it reflected clinical practice, where patients are only treated if they have symptomatic varicose veins. If reflux alone was considered the outcome, patients in the surgery group were significantly advantaged. Hospital costs were considerably reduced, by about $€ 1050$ per patient, when UGFS was used for the treatment of great saphenous varicose veins. 
Table 4. Hospital costs for patients treated by ultrasound-guided foam sclerotherapy or stripping.

\begin{tabular}{|c|c|c|c|c|c|}
\hline & \multirow{2}{*}{$\begin{array}{c}\text { Unit } \\
\text { price }(€)\end{array}$} & \multicolumn{2}{|c|}{ UGFS $(n=230)$} & \multicolumn{2}{|c|}{ Surgery $(n=200)$} \\
\hline & & $\begin{array}{l}\text { No. of patients } \\
\text { using resource }\end{array}$ & $\begin{array}{l}\text { Mean(s.d.) cost } \\
\text { per patient (€) }\end{array}$ & $\begin{array}{l}\text { No. of patients } \\
\text { using resource }\end{array}$ & $\begin{array}{l}\text { Mean(s.d.) cost } \\
\text { per patient ( } €)\end{array}$ \\
\hline \multicolumn{6}{|c|}{ First visit at department of } \\
\hline Dermatology & 98.41 & 230 & $98.41(0.00)$ & - & - \\
\hline Surgery & 143.69 & - & - & 200 & $143.69(0.00)$ \\
\hline Anaesthetics & 380.99 & - & - & 200 & $380.99(0.00)$ \\
\hline \multicolumn{6}{|l|}{ Initial treatment } \\
\hline UGFS & 244.94 & 230 & $244.94(0.00)$ & - & - \\
\hline Stripping & 979.79 & - & - & 200 & $979.79(0.00)$ \\
\hline \multicolumn{6}{|c|}{ Follow-up after initial treatment (months) } \\
\hline 3 & 98.41 & 217 & $92.85(22.78)$ & 176 & $86.60(32.06)$ \\
\hline 12 & 98.41 & 221 & $94.56(19.12)$ & 188 & $92.51(23.43)$ \\
\hline 24 & 98.41 & 213 & $91.14(25.80)$ & 177 & $87.09(31.47)$ \\
\hline \multicolumn{6}{|l|}{ Retreatment } \\
\hline UGFS & 244.94 & 43 & $52.18(117.35)$ & 10 & 13.47(61.13) \\
\hline Stripping & 979.79 & - & - & 2 & $9.80(97.75)$ \\
\hline Follow-up & 98.41 & 30 & $12.84(35.67)$ & 6 & $2.95(16.83)$ \\
\hline \multicolumn{6}{|c|}{ Complementary treatment } \\
\hline UGFS & 244.94 & 16 & $17.03(66.50)$ & 5 & $6.12(38.34)$ \\
\hline Phlebectomy & 228.89 & 26 & $26.00(78.84)$ & 7 & $8.01(42.20)$ \\
\hline Sclerotherapy & 65.31 & 19 & $5.40(18.02)$ & 16 & $5.22(18.93)$ \\
\hline \multicolumn{6}{|l|}{ Complications } \\
\hline $\begin{array}{l}\text { Deep venous } \\
\text { thrombosis }\end{array}$ & 1322.00 & 1 & $5.75(87.17)$ & 0 & - \\
\hline $\begin{array}{l}\text { Pulmonary } \\
\text { embolism }\end{array}$ & 4210.00 & 1 & $18.30(277.60)$ & 0 & - \\
\hline Groin infection & 378.97 & 0 & - & 4 & $7.58(53.19)$ \\
\hline Thrombophlebitis & 200.74 & 17 & $14.84(52.63)$ & 0 & - \\
\hline Total & & 230 & $774.24(344.08)$ & 200 & $1823.82(140.90)$ \\
\hline
\end{tabular}

Comparison with the literature regarding the effectiveness of UGFS and surgery is difficult because of differences in primary outcomes and follow-up. Two other randomized trials have compared UGFS with surgery13,22, but these had a limited follow-up of 1 year. The trial of Rasmussen and colleagues ${ }^{13}$ showed efficacy for both treatments but the technical failure rate (defined as an open part of the treated vein segment greater than $10 \mathrm{~cm}$ in length) was higher after UGFS (16.3 per cent) than after surgery (4.8 per cent). The Varisolve trial of Wright and coworkers ${ }^{22}$ showed success rates of 68.2 per cent for UGFS and 87.2 per cent for surgery after 1 year; surgery was more effective, but UGFS caused less pain and patients resumed their daily routine more quickly. 
In the present study, side-effects such as hyperpigmentation and thrombophlebitis were the most common complications in the UGFS group. One deep venous thrombosis and one pulmonary embolism occurred in the UGFS group. Neither of these patients was at increased risk of thromboembolic events, nor did any sign of post-thrombotic syndrome such as deep venous occlusion or reflux develop during 2 years of follow-up. The rate of thromboembolic events in this study ( 0.4 per cent) corresponds to reported rates of between 0.02 and 1.25 per cent in other studies of UGFS23,24.

UGFS was substantially cheaper than surgery, explained mainly by the lower costs of treatment; UGFS does not require general anaesthesia and can therefore be applied as a simple outpatient procedure. It is acknowledged that real-world costs are probably confounded with study-induced costs, which is the case in many studies that apply an active follow-up scheme. This applies especially to the surgery group as, in routine practice, these patients have only one follow-up visit 10 days after surgery in the study hospitals. In the present study, follow-up visits were planned at 3,12 and 24 months, and these visits may have induced costs (due to retreatment and complementary treatment) that in normal practice would not have been made. Nevertheless, even if all costs related to follow-up in the surgery group are excluded from the analysis, surgery remains more costly. In Western countries, the treatment of varicose veins imposes a considerable burden on the healthcare budgets ${ }^{25,26}$. In the Netherlands, $€ 274$ million a year is spent on the treatment of venous diseases, accounting for 6 per cent of total healthcare costs ${ }^{27}$. Replacing surgery by UGFS would result in a cost reduction of more than $€ 1000$ per patient and could substantially lower the healthcare costs of varicose veins.

Minimally less invasive techniques such as UGFS and endothermal ablation techniques, for example EVLA and RFA, are becoming increasingly popular in the treatment of varicose veins. At the start of the present study, experience with the latter treatment modalities was still limited in the Netherlands, which was the reason to focus on comparison of surgery with UGFS. The results support the trend towards the use of minimally invasive techniques. An advantage of UGFS over endothermal ablation techniques is that tumescent anaesthesia is not required. Moreover, UGFS is easy to learn, making it an accessible treatment modality for a large group of practitioners such as dermatologists, surgeons and radiologists.

This study had some limitations. First, after randomization, 26 patients declined the treatment to which they had been randomized. The fact that 24 patients declined treatment in the surgery group versus two in the UGFS group could indicate that some patients had hoped to be assigned to UGFS. The withdrawal of these patients is unlikely to have affected the study results, because it did not affect the comparability of the two treatment groups. 
Second, blinding was not feasible, because of the visible scars after surgical treatment and obliteration of the GSV after UGFS. However, outcomes were assessed objectively using colour duplex imaging by an analyst not involved in the study. The duplex technician was affiliated to neither the dermatology nor the surgery department. Third, loss to follow-up meant that the intended sample size of 460 patients was not achieved. However, with the actual numbers of 200 patients in the surgery group and 230 in the UGFS group, the post hoc power in this study would have been 92.6 per cent $(a=5$ per cent) to detect a minimal clinically relevant increase in the risk of recurrence of 10 per cent or more after UGFS. Fourth, the number of patients having additional treatments was higher in the surgery group than for UGFS, because it is common practice to perform phlebectomies during a stripping procedure. This lack in comparability of co-interventions may have favoured surgery. Finally, this trial had a limited follow-up of 2 years. Results showed that presence of reflux alone was observed significantly more often after treatment with UGFS. As the presence of reflux is a reliable predictor of symptoms of recurrent varicose veins developing in the future, longer follow-up is required to arrive at definite conclusions.

\section{Acknowledgements}

The authors thank Linda Spijker for collecting data on hospital costs and quality of life, and Monique de Laat for performing the duplex examinations. The study was funded by the Netherlands Organisation for Health Research and Development (ZonMw), which had no role in the study design, the collection, analysis, and interpretation of the data, or the writing of the report. The corresponding author had full access to all data in the study and had final responsibility to submit it for publication.

\section{Conflict of Interest}

Disclosure: The authors declare no conflict of interest. 


\section{References}

1. Wong JK, Duncan JL, Nichols DM. Whole-leg duplex mapping for varicose veins: observations on patterns of reflux in recurrent and primary legs, with clinical correlation. Eur J Vasc Endovasc Surg 2003; 25: 267-275.

2. Engelhorn CA, Engelhorn AL, Cassou MF, Salles-Cunha SX. Patterns of saphenous reflux in women with primary varicose veins. J Vasc Surg 2005; 41: 645-651.

3. Evans CJ, Fowkes FG, Ruckley CV, Lee AJ. Prevalence of varicose veins and chronic venous insufficiency in men and women in the general population: Edinburgh Vein Study. J Epidemiol Community Health 1999; 53: 149-153.

4. Eberhardt RT, Raffetto JD. Chronic venous insufficiency. Circulation 2005; 111:2398-2409.

5. Hobbs JT. Surgery and sclerotherapy in the treatment of varicose veins. A random trial. Arch Surg 1974; 109: 793-796.

6. Lofgren KA, Ribisi AP, Myers TT. An evaluation of stripping versus ligation for varicose veins. AMA Arch Surg 1958; 76: 310-316.

7. van Rij AM, Jiang P, Solomon C, Christie RA, Hill GB. Recurrence after varicose vein surgery: a prospective long-term clinical study with duplex ultrasound scanning and air plethysmography. JVasc Surg 2003; 38: 935-943.

8. Fischer R, Linde N, Duff C, Jeanneret C, Chandler JG, Seeber P. Late recurrent saphenofemoral junction reflux after ligation and stripping of the greater saphenous vein. J Vasc Surg 2001; 34: 236-240.

9. Neglen P. Long saphenous stripping is favored in treating varicose veins. Dermatol Surg 2001; 27: $901-$ 902.

10. Kanwar A, Hansrani M, Lees T, Stansby G. Trends in varicose vein therapy in England: radical changes in the last decade. Ann R Coll Surg Engl 2010; 92: 341-346.

11. Rabe E, Otto J, Schliephake D, Pannier F. Efficacy and safety of great saphenous vein sclerotherapy using standardised polidocanol foam (ESAF): a randomised controlled multicentre clinical trial. Eur J Vasc Endovasc Surg 2008; 35: 238-245.

12. Yamaki T, Nozaki M, Iwasaka S. Comparative study of duplex-guided foam sclerotherapy and duplexguided liquid sclerotherapy for the treatment of superficial venous insufficiency. Dermatol Surg 2004; 30: 718-722.

13. Rasmussen LH, Lawaetz M, Bjoern L, Vennits B, Blemings A, Eklof B. Randomized clinical trial comparing endovenous laser ablation, radiofrequency ablation, foam sclerotherapy and surgical stripping for great saphenous varicose veins. Br J Surg 2011; 98: 1079-1087.

14. Hamel-Desnos C, Ouvry P, Benigni JP, Boitelle G, Schadeck M, Desnos P et al. Comparison of $1 \%$ and $3 \%$ polidocanol foam in ultrasound guided sclerotherapy of the great saphenous vein: a randomised, double-blind trial with 2 year-follow-up. 'The 3/1 Study'. Eur J Vasc Endovasc Surg 2007; 34: 723-729.

15. Barrett JM, Allen B, Ockelford A, Goldman MP. Microfoam ultrasound-guided sclerotherapy treatment for varicose veins in a subgroup with diameters at the junction of $10 \mathrm{~mm}$ or greater compared with a subgroup of less than $10 \mathrm{~mm}$. Dermatol Surg 2004; 30: 1386-1390.

16. Beale RJ, Gough MJ. Treatment options for primary varicose veins - a review. Eur J Vasc Endovasc Surg 2005; 30: 83-95.

17. Teruya TH, Ballard JL. New approaches for the treatment of varicose veins. Surg Clin North Am 2004; 84: 1397-1417, viii-ix.

18. Darvall KA, Bate GR, Adam DJ, Bradbury AW. Recovery after ultrasound-guided foam sclerotherapy compared with conventional surgery for varicose veins. Br J Surg 2009; 96: 1262-1267.

19. Lamers LM, McDonnell J, Stalmeier PF, Krabbe PF, Busschbach JJ. The Dutch tariff: results and arguments for an effective design for national EQ-5D valuation studies. Health Econ 2006; 15: 1121-1132.

20. Fleiss JL. Statistical Methods for Rates and Proportions (2nd edn). John Wiley: New York, 1981.

21. Ten Cate-Hoek AJ, Toll DB, Buller HR, Hoes AW, Moons KG, Oudega R et al. Cost-effectiveness of ruling out deep venous thrombosis in primary care versus care as usual. J Thromb Haemost 2009; 7: 2042-2049. 
22. Wright D, Gobin J, Bradbury A. Varisolve polidocanol microfoam compared with surgery or sclerotherapy in the management of varicose veins in the presence of trunk vein incompetence: European randomized controlled trial. Phlebology 2006; 4: 180-190.

23. Ceulen RP, Bullens-Goessens YI, Pi-Van de Venne SJ, Nelemans PJ, Veraart JC, Sommer A. Outcomes and side effects of duplex-guided sclerotherapy in the treatment of great saphenous veins with $1 \%$ versus $3 \%$ polidocanol foam: results of a randomized controlled trial with 1-year follow-up. Dermatol Surg 2007; 33 : 276-281.

24. Guex JJ, Allaert FA, Gillet JL, Chleir F. Immediate and midterm complications of sclerotherapy: report of a prospective multicenter registry of 12173 sclerotherapy sessions. Dermatol Surg 2005; 31: 123-128.

25. Subramonia S, Lees T. Radiofrequency ablation vs conventional surgery for varicose veins - a comparison of treatment costs in a randomised trial. Eur J Vasc Endovasc Surg 2010; 39: 104-111.

26. Allegra C. Chronic venous insufficiency: the effects of health-care reforms on the cost of treatment and hospitalisation - an Italian perspective. Curr Med Res Opin 2003; 19: 761-769.

27. Oostenbrink JB, Koopmanschap MA, Rutten FFH. Handleiding voor Kostenonderzoek: Methoden en Richtlijnprijzen voor Economische Evaluaties in de Gezondheidszorg. College voor Zorgverzekeringen: Amstelveen, 2000. 

Chapter 4

\section{How specific are venous symptoms for diagnosis of CVD?}

Van der Velden SK, Shadid NH, Nelemans PJ, Sommer A

Submitted to Phlebology 


\section{Abstract}

Objective: The objective of this study is to evaluate whether and which 'venous' symptoms are characteristic for patients affected with chronic venous disease (CVD) compared to patients with other diseases of the lower limbs (e.g. arthrosis, peripheral arterial disease, spinal disc herniation).

Methods: A cross sectional study was performed to compare the frequency of venous symptoms among 76 patients with chronic venous disease (CVD) and reflux and 74 patients with other diseases of the legs without reflux. The VEINES-Sym of the VEINES-QOL/Sym questionnaire was used to evaluate the frequency of symptoms. Demographic, clinical classification and ultrasound findings were also noted.

Results: A total of 122 patients were included for analysis (response rate of $87 \%$ ). Presence of venous symptoms was slightly more often reported in the CVD group than in the nonCVD group, but differences were small and statistically non-significant. Severity of CVD as classified by the CEAP classification was not associated with higher proportions of patients reporting symptoms than in non-CVD patients, except for swelling $(p=.016)$ and itching $(p=.007)$ in C3-C6 patients. The largest difference between the CVD and non-CVD group was observed for the time of the day at which symptoms were most intense; patients with CVD were more likely to experience symptoms at the end of the day $(p<.001)$.

Conclusions: The small differences in prevalence of reported "venous" symptoms between CVD patients and patients with other diseases of the legs suggest that these symptoms may be less specific for patients with refluxing veins than is usually assumed. 


\section{Introduction}

Chronic venous disease (CVD) is a common health problem in Western countries affecting about one quarter of the adult population'. It is commonly assumed that this condition is associated with symptoms such as tingling, aching, burning, pain, muscle cramps, swelling, sensation of throbbing or heaviness, itching skin, restless legs, leg-tiredness and/or fatigue. In daily practice, the presence of one or more venous symptoms, together with clinical and duplex ultrasound findings of venous disease is an indication for the treatment of varicose veins.

However, equivocal results from previous studies suggest that the association between chronic venous disease and venous symptoms may not always be that strong as is assumed and that these symptoms may also have a non-venous cause ${ }^{2,3}$. Furthermore, it has been observed that despite successful treatment of the refluxing saphenous trunk, reduction of symptoms such as restless legs, oedema, cramps, pain and heavy or tired feeling, was reached in only part (40-83\%) of the treated patients ${ }^{4-6}$. Alternatively, local recurrences of varicose veins or recanalized refluxing veins on duplex ultrasound are not always correlated with the presence of symptoms ${ }^{7,8}$. These observations raise the question, to what extent venous symptoms are specific for patients with CVD and reflux.

The prevalence of chronic venous disease is increasing with age and in particular the older population is affected with CVD'. In this population, the relationship between symptoms and presence of reflux may be further obscured by the presence of other diseases of the lower limbs, such as hip or knee arthrosis, peripheral arterial disease or spinal disc herniation which may cause comparable symptoms in the leg. The present study explores this issue by comparing the distribution of symptoms between a patient group with chronic venous disease and a patient group with other diseases of the legs. The underlying hypothesis was that the so-called venous symptoms (tingling, aching, burning, pain, muscle cramps, swelling, sensation of throbbing or heaviness, itching skin, restless legs, leg-tiredness and/or fatigue) are non -specific for patients with chronic venous disease. The secondary objective was to compare the mean number of symptoms, the mean symptom score and the time of the day at which symptoms were experienced as most intense. 


\section{Methods}

\section{Patients}

This study was performed in the outpatient clinics of Dermatology, Neurology, Vascular surgery and Orthopaedics at the Maastricht University Medical Centre between November 2010 and June 2011. Eligible were patients older than 18 years visiting the outpatient department of Dermatology with one or more venous symptoms. Patients of the outpatient departments of Vascular Surgery, Orthopedics or Neurology visiting because of complaints of the leg(s) due to peripheral arterial disease (PAD), knee or hip arthrosis (AR) or spinal disc herniation (SDH), respectively, were also eligible. Diagnosis was confirmed by ankle brachial index and arterial pulse- wave Doppler recordings, X-ray or Magnetic Resonance imaging (MRI), respectively.

A trained physician examined patient's affected legs and classified them according to the clinical component (' $C$ ') of the CEAP classification'. Venous signs, such as telangiectasia, reticular veins, varicose veins, edema, skin changes (hyperpigmentation, lipodermatosclerosis) or ulceration were recorded. Subsequently, ultrasound examination of both superficial and deep venous systems was performed in standing position ${ }^{10}$. All patients in the CVD group had to have symptoms of venous disease and confirmed saphenous trunk reflux (>0.5 seconds) on duplex ultrasound. Patients with other diseases of the legs (peripheral arterial disease, knee or hip arthrosis or spinal disc herniation) were excluded if saphenous trunk reflux of more than 0.5 seconds on duplex ultrasound was observed. We hypothesized that patients affected with clinical classes C5 or C6 would report more symptoms than patients affected with C1-C4 disease ${ }^{11}$. However, in clinical practice, $\mathrm{C} 5$ or $\mathrm{C} 6$ disease is relatively rare in patients affected with varicose veins compared to the other clinical classes. Therefore, we aimed to include 20 patients with healed or active ulceration of the lower leg.

Patients gave written informed consent to participate in the study.

\section{Questionnaire}

Patients were asked to complete the VEINES- Sym of the VEINES-QOL/Sym questionnaire ${ }^{12}$. Patients were requested to complete the questionnaires at home and return it by prepaid mail. In case of missing questionnaire items, patients were contacted by phone in order to retrieve the missing data.

The VEINES-Sym is part of the VEINES-QOL/Sym questionnaire and measures symptom frequency and severity. The VEINES-Sym consists of ten items including nine venous symptoms (heavy legs, aching legs, swelling, night cramps, heat or burning sensation, 
restless legs, throbbing, itching, tingling sensation) rated on a five-point scale of frequency ( $1=$ every day, $2=$ several times a week, $3=$ =about once a week, 4=less than once a week, $5=$ never) and leg pain, rated on a 6 -point scale of intensity ( $1=$ very severe, $2=$ severe, $3=$ moderate, $4=$ mild, $5=$ very mild, $6=$ none). In this study, we focused on these nine venous symptoms of frequency. In addition, descriptive information concerning the time of the day at which the symptoms are experienced most intensely was recorded (e.g. on walking, at mid-day, at the end of the day, during the night, at any time of the day, never). Summary symptom scores (VEINES-Sym) were computed from these ten items. The presence of lower VEINES-Sym scores indicates more severe symptoms (range 0-100).

\section{Statistical analysis}

Patients were categorized into two groups according to the reported frequency of symptoms:'every day/several times a week/about once a week/less than once a week' versus 'never'. Proportions and absolute numbers of patients who reported presence of a specific symptom were compared between patients with and without CVD using the Chi-square test. In an additional analysis subgroups of patients reporting a specific symptom 'every day' was compared to the subgroup of patients who experienced that specific symptom less than every day several times a week or less.

Patients with missing scores on three or more items were excluded from the analysis. For patients with missing scores on one or two items, missing values were imputed by median values on the completed items reported by an individual. To calculate VEINES-Sym scores, raw scores were first transformed to $z$ score equivalents (mean 0 ; standard deviation 1) which then are transformed to T scores (mean 50, standard deviation 10) ${ }^{12}$.

All analyses were performed using SPSS (SPSS Inc., Chicago, IL, U.S.A.). Two sided P values of 0.05 or less were considered to indicate statistical significance.

\section{Results}

\section{Study population}

Eligible were 76 CVD patients with confirmed reflux and 74 patients with AR, SDH or PAD without clinical signs of CVD (25 AR, 23 SDH, 26 PAD) (Figure 1).

A total of 132 patients completed the questionnaire. The response rate was $88 \%(69 / 77)$ in the CVD group and $86 \%$ (64/74) in the group with other diseases of the legs. Questionnaires were incomplete in 10 patients resulting in a total sample of 122 patients remaining for analysis. 

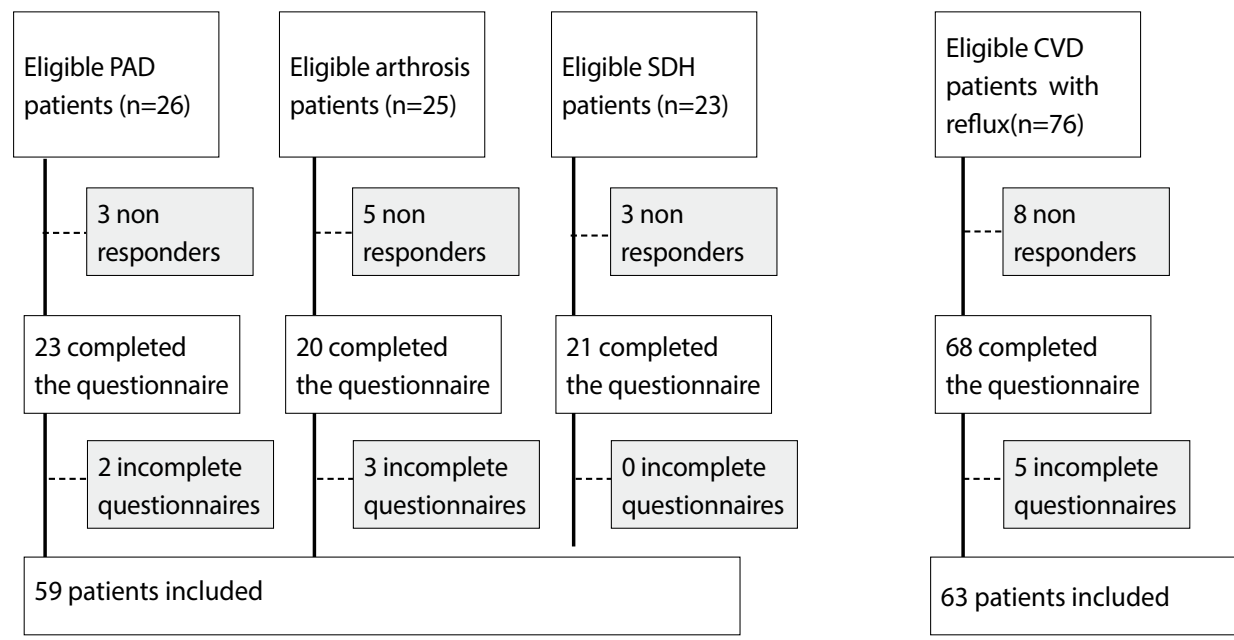

Figure 1. Flowchart. Abbreviations: $P A D$, peripheral arterial disease; $S D H$, spinal disc herniation; $A R$, arthrosis; $C V D$, chronic venous disease.

Table 1 summarizes the distribution of baseline characteristics in the various subgroups. It can be observed that $62 \%$ of the patients with CVD were female and the mean age was 61 years (SD 13, range 30-94; table 1). In the non-venous disease group, half of the patients were female and the mean age was 59 years (SD 12, range 32-83). Five patients (8\%) of the CVD group showed a combination of superficial and deep venous insufficiency. One patient only had deep venous insufficiency. C3-C6 venous disease was present in 57\% of the CVD group and in $7 \%$ of the patients in the group with other leg diseases.

\section{Presence of venous symptoms according to diagnosis}

Seven out of nine symptoms (heavy legs, aching legs, swelling, night cramps, restless legs, itching and tingling) were reported by more than $50 \%$ of the patients in the CVD group. This finding is in contrast to the patients in the non-CVD group where only four out of nine symptoms (heavy legs, aching legs, night cramps and tingling) were reported by more than half of the patients (Figure 2). Higher proportions in the CVD group were observed for six symptoms: heavy legs (67\% vs $61 \%)$, swelling ( $52 \%$ vs $31 \%$,), night cramps $(71 \%$ vs $53 \%)$, restless legs ( $51 \%$ vs $47 \%$ ), throbbing ( $40 \%$ vs $29 \%$ ) and itching ( $52 \%$ vs $31 \%)$; (Table 2.$)$ However, no statistical significance was reached. Presence of aching legs, heat or burning sensation and tingling was reported by a higher proportion of patients in the non-CVD group (Table 2).

When patients were categorized according to frequencies of symptoms every day versus less than every day, the differences in proportions of patients between both groups increased only for aching legs ( $32 \%$ vs $49 \%, p=0.05$ ). 
Table 1. Distribution of patient characteristics.

\begin{tabular}{|c|c|c|c|c|}
\hline & CVD, n(\%) & SDH, n(\%) & PAD, n(\%) & $A R, n(\%)$ \\
\hline \multicolumn{5}{|l|}{ Sex } \\
\hline Male & $24(38 \%)$ & $13(62 \%)$ & $13(62 \%)$ & $4(24 \%)$ \\
\hline Female & $39(62 \%)$ & $8(38 \%)$ & $8(38 \%)$ & $13(76 \%)$ \\
\hline \multicolumn{5}{|l|}{ Age } \\
\hline Mean & 61 & 52 & 64 & 62 \\
\hline (SD, min-max) & $(13,30-94)$ & $(12,33-83)$ & $(9,45-80)$ & $(12,36-83)$ \\
\hline \multicolumn{5}{|l|}{ Clinical classes } \\
\hline $\mathrm{CO}$ & 0 & $5(24 \%)$ & $11(52 \%)$ & $3(18 \%)$ \\
\hline C1 & $7(11 \%)$ & $13(62 \%)$ & $5(24 \%)$ & $12(72 \%)$ \\
\hline $\mathrm{C} 2$ & $20(32 \%)$ & $2(10 \%)$ & $3(14 \%)$ & $1(5 \%)$ \\
\hline $\mathrm{C} 3$ & $16(25 \%)$ & $1(4 \%)$ & $2(10 \%)$ & $1(5 \%)$ \\
\hline $\mathrm{C} 4$ & $2(3 \%)$ & $0(0 \%)$ & $0(0 \%)$ & $0(0 \%)$ \\
\hline C5 & $1(2 \%)$ & $0(0 \%)$ & $0(0 \%)$ & $0(0 \%)$ \\
\hline C6 & $17(27 \%)$ & $0(0 \%)$ & $0(0 \%)$ & $0(0 \%)$ \\
\hline \multicolumn{5}{|l|}{ Reflux } \\
\hline Superficial system & $63(100 \%)$ & $0(0 \%)$ & $0(0 \%)$ & $0(0 \%)$ \\
\hline Perforating veins & $1(2 \%)$ & $0(0 \%)$ & $0(0 \%)$ & $0(0 \%)$ \\
\hline Deep system & $6(10 \%)$ & $0(0 \%)$ & $0(0 \%)$ & $0(0 \%)$ \\
\hline
\end{tabular}

Abbreviations: CVD, chronic venous disease; PAD, peripheral arterial disease; $\mathrm{SDH}$, spinal disc herniation; $\mathrm{AR}$, arthrosis.

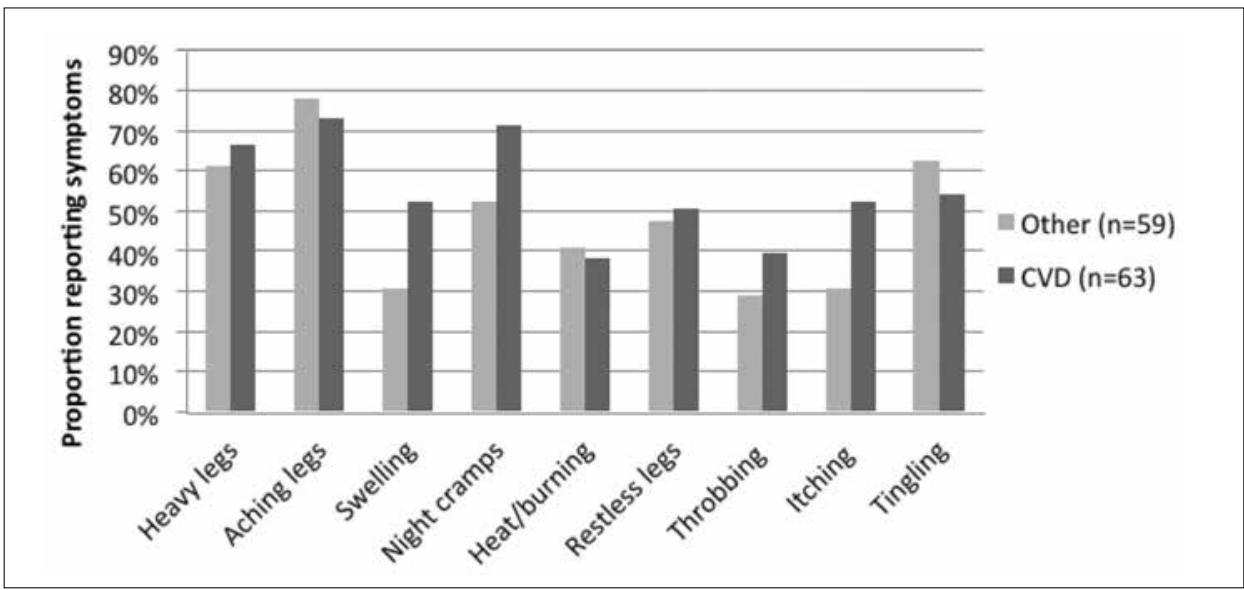

Figure 2. Proportions of patients with presence of symptoms among patients with chronic venous disease (CVD) and 'other' non-CVD patients (including; arthrosis, peripheral arterial disease, spinal disc herniation). 
Table 2. Proportions of patients with presence of symptoms among patients with chronic venous disease (CVD), categorized according to clinical class, and 'other' non-CVD patients (including: arthrosis, spinal disc herniation and peripheral arterial disease).

\begin{tabular}{|l|c|c|c|c|}
\hline & $\begin{array}{c}\text { Non-CVD } \\
\text { N=59 }\end{array}$ & $\begin{array}{c}\text { CVD } \\
\text { N=63 }\end{array}$ & $\begin{array}{c}\text { CVD (C1-C2) } \\
\text { N=27 }\end{array}$ & $\begin{array}{c}\text { CVD (C3-C6) } \\
\text { N=36 }\end{array}$ \\
\hline Heavy legs & $61 \%$ & $67 \%$ & $70 \%$ & $64 \%$ \\
\hline Aching legs & $78 \%$ & $73 \%$ & $74 \%$ & $72 \%$ \\
\hline Swelling & $31 \%$ & $52 \%$ & $48 \%$ & $56 \%$ \\
\hline Night cramps & $53 \%$ & $71 \%$ & $70 \%$ & $72 \%$ \\
\hline Heat/burning & $41 \%$ & $38 \%$ & $37 \%$ & $39 \%$ \\
\hline Restless legs & $47 \%$ & $51 \%$ & $59 \%$ & $44 \%$ \\
\hline Throbbing & $29 \%$ & $40 \%$ & $30 \%$ & $47 \%$ \\
\hline Itching & $31 \%$ & $52 \%$ & $44 \%$ & $58 \%$ \\
\hline Tingling & $63 \%$ & $54 \%$ & $63 \%$ & $47 \%$ \\
\hline
\end{tabular}

\section{Clinical severity and presence of symptoms}

Patients in the CVD group were categorized according to clinical classes (C1-C2 versus C3C6) and these categories were compared with the non-CVD group (Table 2). The difference in proportion of patients with presence of symptoms between the CVD and non-CVD group increased for the symptoms swelling, night cramps, throbbing and itching if only the CVD patients with clinical class C3-C6 were taken into consideration. In the latter comparison, statistically significant difference was reached for the symptoms swelling $(p=.016)$ and itching ( $p=.007$ ) When we categorized patients according to frequencies of symptoms 'every day' versus 'less than every day' the differences between the CVD with clinical class C3-C6 and non-CVD group did not increase.

\section{Number of venous symptoms according to diagnosis}

Patients were allocated according to the number of reported symptoms (out of a total of nine) into four groups: 0 symptoms, 1-3 symptoms, 4-6 symptoms and 7-9 symptoms. In both the CVD and non-venous group 44\% of the patients presented with 4-6 symptoms (Figure 3). In addition, the proportion of patients with 7-9 symptoms in the CVD group was not much higher than in patients affected by other diseases of the leg (29\% versus $14 \%$ ).

When we calculated the summary Sym-scores of the non-CVD and CVD group, both groups showed similar mean scores (50 versus 51). Mean Sym-scores decreased when we compared clinical classes C3-C6 to clinical classes C1-C2 (49 versus 51), indicating a deterioration of symptoms. 


\section{Time of the day at which symptoms are experienced most intensely}

For half of the patients with CVD symptoms were most intense at the end of the day versus $21 \%$ of patients affected by other disease of the legs ( $p<.001$ ) (Figure 4$)$. The latter group of patients was more likely to experience their symptoms at any time of the day (40\%).

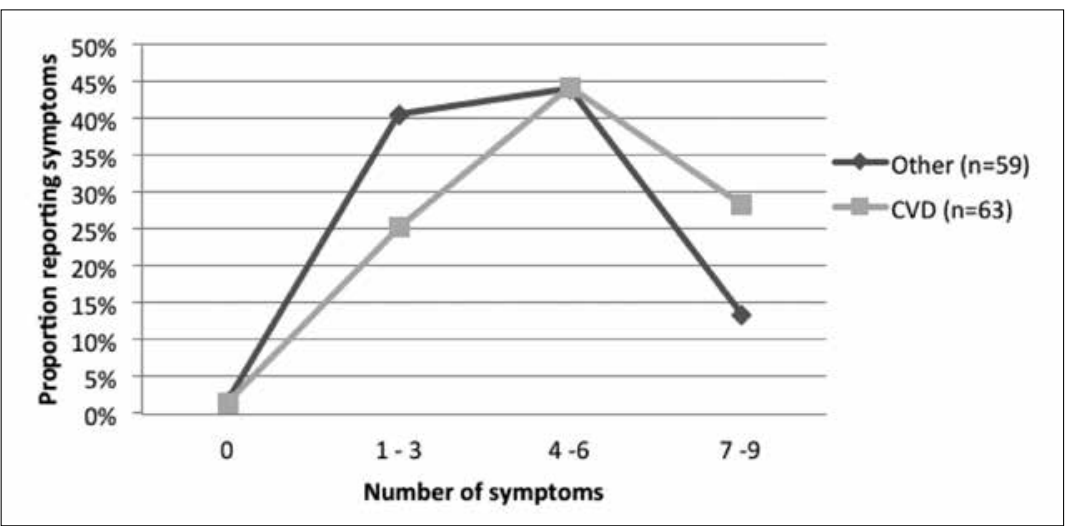

Figure 3. Proportions of patients with a total number of 0, 1-3, 4-6 and 7-9 symptoms according to diagnosis.

Abbreviation: CVD, chronic venous disease. Other includes: patients affected with arthrosis, spinal disc herniation and peripheral arterial disease.

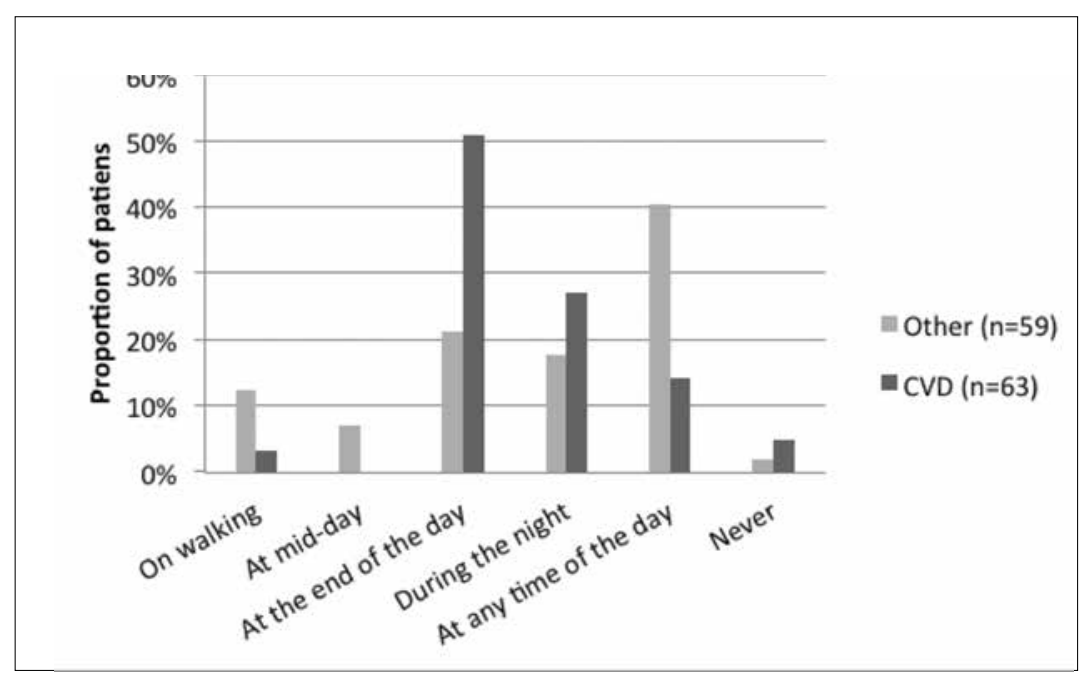

Figure 4. Time of the day that symptoms are experienced most intense.

Abbreviation: CVD, chronic venous disease. Other includes: patients affected with arthrosis, spinal disc herniation and peripheral arterial disease. 


\section{Discussion}

This study showed that the majority of symptoms that are commonly attributed to chronic venous disease (heavy legs, swelling, night cramps, restless legs, throbbing and itching) are slightly more often reported in patients affected by chronic venous disease compared to patients affected with other diseases of the lower legs. Furthermore, there was no strong correlation between type of symptoms and extent and severity of CVD. When CVD patients with clinical class C3-C6 were compared with patients with other leg diseases, differences were small and statistical significance was only reached for the symptoms swelling and itching. The largest difference between the CVD and non-CVD group was observed with respect to the timing of symptoms. Patients with CVD are more likely to experience symptoms at the end of the day than patients who have symptoms due to other diseases of the legs.

In the present study the mean VEINES-Sym summary score was comparable to that found in other studies ${ }^{11,13}$. Kahn et al reported mean Sym scores of 50.5 in males and 49.8 in females. As Kurz et al already demonstrated, mean Sym scores decrease with higher clinical classes, ranging from 52.3 for clinical class 1 to 43.1 for clinical classes $\mathrm{C} 5-\mathrm{C} 6^{13}$. However, although mean scores were slightly lower in clinical classes C3-C6 versus clinical classes C1-C2, a significant decrease in mean Sym scores with increasing severity could not be confirmed in this study.

The considerable overlap between venous symptoms reported by patients with chronic venous disease and by patients with other diseases of the lower leg confirms lack of specificity of symptoms. Marston et $\mathrm{al}^{14}$ postulated that none of the venous symptoms are specific to venous disease and multiple etiologies may be confused with chronic venous disease. The population based Bonn Vein Study revealed that $62.1 \%$ of women and $49.1 \%$ of men reported leg symptoms, but only $27,8 \%$ of men and $34,1 \%$ of women had CVD with clinical class above $C 2$ and only $21.0 \%$ had reflux in the superficial venous system ${ }^{15,16}$. The Edinburgh Vein Study also showed that lower limb symptoms are not only caused by venous problems. Venous symptoms such as aching and cramps were reported by $54 \%$ and $34 \%$, respectively, in the general population ${ }^{3}$. The San Diego Population study related symptoms to venous disease and found that swelling, heaviness and itching were reported by participants with visible or functional venous disease about twice as often than by participants with normal legs, but for other symptoms the contrasts were less strong ${ }^{2}$.

Interestingly, we observed a statistically significant difference between both groups in proportion of patients that experienced their symptoms most intensely at the end of the day. This finding is in line with another study that showed that circumstances that 
elicit or exacerbate symptoms were more characteristic for CVD rather than the number of symptoms or symptom type ${ }^{17}$. Several studies already emphasized the importance of a thorough medical history to evaluate the circumstances that elicit and exacerbate symptoms (the time of the day, relief of symptoms by elevation of the legs) and physical examination in combination with venous ultrasound examination 14,17,18. However, available questionnaires do not incorporate questions, which explicitly address such symptom provoking factors. The reason why we used the VEINES-Sym for this study is that it is the most thorough and comprehensive questionnaire on symptom type and symptom frequency that is currently available. Other questionnaires such as the Chronic Lower Limb Venous Insufficiency (CIVIQ), and Aberdeen Varicose Vein Questionnaire (AVVQ) rather focus on impairment of health related quality of life and clinical class related items and to a lesser extent on symptoms 19,20. The VEINES-Sym questionnaire includes one question concerning at what time of the day the symptoms are most intense. However, precisely this question is not included for calculation of the mean summary Sym-scores and is only used to provide descriptive information ${ }^{12}$.

The present study has a few limitations. First, the relatively small group of patients could be an explanation for the lack of statistically significant differences between both groups. The sample size in this study allowed for detection of absolute differences of $25 \%$ or more in proportions of reported symptoms with a power of $90 \%$ and two-sided alpha of $5 \%$. It was assumed that for discriminative purposes substantial differences in proportions are required and that in this respect detection of smaller differences may not be very relevant. Second, we did not include a control group of healthy subjects and therefore we were not able to compare the results of the patients with CVD to the proportion of healthy patients reporting symptoms.

In conclusion, the lack of difference in prevalence of reported "venous" symptoms between CVD patients with confirmed reflux and patients with other diseases of the legs suggest that these symptoms may be less specific for patients with refluxing veins than is usually assumed. This finding implies that venous symptom questionnaires that only address type and frequency of these symptoms may have limited ability to identify patients with CVD and reflux. There seems to be room for improvement of questionnaires for CVD, including specific questions about circumstances that elicit and exacerbate or alleviate symptoms.

\section{Acknowledgements}

We would like to thank Marianne de Maeseneer for her kind help and contribution in reviewing the article. We also would like to thank Menno Pardoel for his help and contribution with the analysis. 


\section{References}

1. Evans $\mathrm{CJ}$, Fowkes FG, Ruckley CV, et al. Prevalence of varicose veins and chronic venous insufficiency in men and women in the general population: Edinburgh Vein Study. J Epidemiol Community Health. 1999 Mar;53(3):149-53

2. Langer RD, Ho E, Denenberg JO, et al. Relationships between symptoms and venous disease: the San Diego population study. Arch Intern Med. 2005 Jun 27;165(12):1420-4

3. Bradbury A, Evans $C$, Allan $P$, et al. What are the symptoms of varicose veins? Edinburgh vein study cross sectional population survey. BMJ. 1999 Feb 6;318(7180):353-6.

4. Baker DM, Turnbull NB, Pearson JC, et al. How successful is varicose veins surgery? A patient outcome study following varicose vein surgery using the SF-36 health assessment questionnaire. Eur J VascEndovasc Surg. 1995 Apr;9(3):299-304.

5. Hamel- Desnos CM, Guias BJ, Desnos PR, et al. Foam sclerotherapy of the saphenous veins: randomized controlled trial with or without compression. Eur J Vasc Endovasc Surg. 2010 Apr;39(4):500-7

6. Shadid N, Ceulen R, Nelemans P, et al. Randomized clinical trial of ultrasound-guided foam sclerotherapy versus surgery for the incompetent great saphenous vein. Br J Surg. 2012 Aug;99(8):1062-70.

7. Saarinen J, Suominen V, Heikkinen $M$, et al. The profile of leg symptoms, clinical disability and reflux in legs with previously operated varicose disease. Scand J Surg. 2005;94(1):51-5.

8. Merchant, R. F., O. Pichot and Closure Study Group. Long-term outcomes of endovenous radiofrequency obliteration of saphenous reflux as a treatment for superficial venous insufficiency. JVasc Surg 42(3): 502509

9. Vasquez MA and Munschauer CE. Revised venous clinical severity score: a facile measurement of outcomes in venous disease. Phlebology. 2012 Mar;27 Suppl 1:119-29

10. Coleridge Smith P, Labropoulos N, Partsch $\mathrm{H}$, et al. Duplex ultrasound investigation of the veins in chronic venous disease of the lower limbs - UIP consensus document. Part I. Basic principles. Eur JVasc Endovasc Surg. 2006 Jan;31(1):83-92

11. Kahn SR, M'lan CE, Lamping DL, et al. Relationship between clinical classification of chronic venous disease and patient-reported quality of life: results from an international cohort study. J Vasc Surg. 2004 Apr;39(4):823-8.

12. Lamping $\mathrm{DL}$, Abenheim $\mathrm{L}$, Kurz $\mathrm{X}$, et al. Measuring quality of life and symptoms in chronic venous disorders of the leg: development and psychometric evaluation of the VEINES-QOL/VEINES-Sym questionnaire. Qual Life Res 1998; 7: 621-622

13. Kurz X, Lamping DL, Kahn SR, et al. Do varicose veins affect quality of life? Results of an international population-based study. VEINES Study Group. J Vasc Surg. 2001 Oct;34(4):641-8

14. Marston WA. Evaluation of varicose veins: What do the clinical signs and symptoms reveal about the underlying disease and need for intervention? SeminVasc Surg. 2010 Jun;23(2):78-84

15. Rabe E, Pannier-Fischer F, Bromen K, et al. BonnerVenenstudie der Deutschen Gesellschaft für Phlebologie - Epidemiologische Untersuchung zur Frage der Häufigkeit und Ausprägung von chronischen Venenkrankheiten in der städtischen und ländlichen Wohnbevölkerung. Phlebologie. 2003;32:1-14

16. Maurins $\mathrm{U}$, Hoffmann BH, Lösch C, et al. Distribution and prevalence of reflux in the superficial and deep venous system in the general population--results from the Bonn Vein Study, Germany.J Vasc Surg. 2008 Sep;48(3):680-7

17. Carpentier PH, Poulain C, Fabry R, et al; Venous Working Group of the Société Française de Médecine Vasculaire. Ascribing leg symptoms to chronic venous disorders: The construction of a diagnostic score. J Vasc Surg. 2007 Nov;46(5):991-6

18. Campbell WB, Decaluwe H, Boecxstaens V, et al. Eur J Vasc Endovasc Surg. The symptoms of varicose veins: difficult to determine and difficult to study. 2007 Dec;34(6):741-4

19. Launois R, Reboul-marty J and Henry B. Construction and validation of quality of life questionnaire in Chronic Lower Limb venous Insufficiency (CIVIQ). Qual Life Res 1996;5:539-54

20. Garratt A, Schmidt L, Mackintosh A, et al. Quality of life measurement: bibliographic study of patient assessed health outcome measure. BMJ 2002;324:1417 


Chapter 5

Superficial thrombophlebitis of the

venous dorsal arch of the foot and deep venous thrombosis after foam sclerotherapy

Nadia Shadid, Jorge Frank and Anja Sommer

Int J Dermatol. 2008 Nov;47 Suppl 1:29-31 


\section{Abstract}

Four days after foamsclerotherapy of an incompetent great saphenous vein of the left lower leg a 49-year-old woman developed a superficial thrombophlebitis of the venous dorsal arch. In the course of follow-up repeated color duplex sonography initially did not show involvement of the deep venous system and, hence, she was treated with nonsteroidal anti-inflammatory drugs and compression hosiery. However, six weeks after foam treatment we diagnosed a deep venous thrombosis (DVT) of the popliteal vein and started an oral anticoagulant therapy. Although rarely observed, DVT is among the most serious complications of foamsclerotherapy Therefore, we suggest that the occurrence of a superficial thrombophlebitis that is not located in close vicinity of the vein treated should be an indication for regular follow-up examinations to prevent missing the occurrence of disease progression and a possible involvement of the deep venous system. 


\section{Introduction}

Varicose veins are one of the most common blood vessel problems in the general population. With a female preponderance, the prevalence of varicoses increases with age. ${ }^{1}$

For decades, surgery has been the therapy of first choice for the treatment of patients with venous diseases of the lower limb attributable to truncal saphenous incompetence. ${ }^{2}$ The introduction of vascular ultrasound, however, has led to an interest in distinct therapeutic endovenous obliteration techniques, including radiofrequency methods, endovascular laser treatment, and foam sclerotherapy. Ultrasound-guided sclerotherapy with foam is a novel further development of traditional sclerotherapy, and several studies have demonstrated great effectiveness of $70-93 \%$ in the closure of saphenous trunks by this technique.2,3

Foam sclerotherapy constitutes a minimally invasive treatment modality for varicose veins that is patient friendly, safe, inexpensive, easy to use in experienced hands, requires only a minimum of equipment, and has a low complication rate. It is a chemical ablation technique that induces endothelial cell destruction, leading to the formation of a clot. $A$ fully organized thrombus is usually formed after 4 weeks and, eventually, intimal fibroplasia results in endofibrosis. ${ }^{3}$

\section{Case Report}

A 49-year-old woman was referred to our phlebology outpatient unit with complaints of heaviness, tiredness, and cramps in both legs. Her medical history revealed a saphenofemoral ligation and a short stripping of the great saphenous veins (GSVs) in both legs. Her general health status was good and her further medical history was unremarkable apart from menopausal transition problems that were being treated with ethinylestradiol/gestodene (Femodene").

On physical examination, there were some telangiectatic and reticular veins on both legs, but no other signs indicative of chronic venous insufficiency. Color duplex sonographic examination revealed an insufficiency of the right small saphenous vein (SSV), but the remaining superficial and deep venous system was sufficient. Her left leg showed a recurrent GSV with an insufficiency extending from the Hunter perforans (mid-thigh perforans) to the ankle. No incompetent perforating veins were observed and the further superficial and deep systems were sufficient.

The insufficient right SSV was treated with endovascular laser therapy. For the recurrent left GSV, foam sclerotherapy was applied using a single $4 \mathrm{ml}$ injection of $3 \%$ polidocanol foam 
administered $15 \mathrm{~cm}$ below the knee upwards to the point of strongest reflux. Subsequently, a pelotte and elastic stockings were applied. Four days after treatment, however, the patient returned to the department with a very painful and swollen left foot (Figure 1).

On clinical examination, a pitting edema was noted on the medial aspect of the foot, malleolus, and distal part of the lower leg. Duplex sonography showed a non-compressible venous dorsal arch and an open and sufficient deep venous system (Figure 2). A diagnosis of superficial thrombophlebitis was made and the patient was started on combination therapy with diclofenac $3 \times 50 \mathrm{mg} /$ day, pantoprazole $20 \mathrm{mg} /$ day, and compressive bandaging. To detect possible progression into the deep venous system, duplex sonography was performed twice weekly. After 6 weeks, the edema and pain had almost completely resolved.

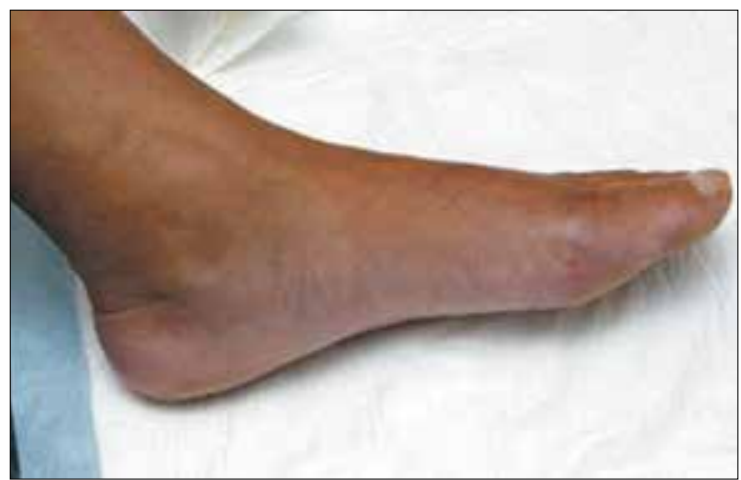

Figure 1. Pitting edema in the left foot

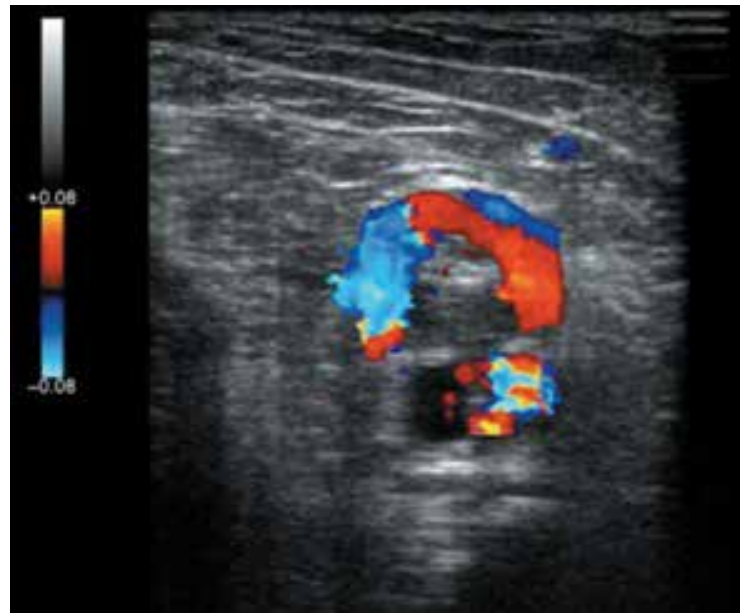

Figure 3: Deep venous thrombosis in the left popliteal vein

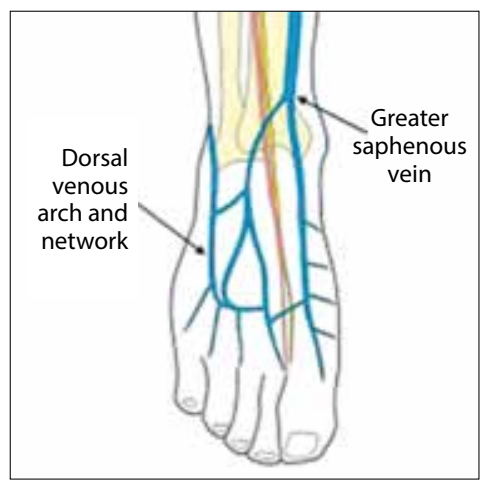

Figure 2. Anatomy of the dorsal arch vein 
Nevertheless, an ultrasound examination after week six of follow-up showed a clot in the center of the left popliteal vein with some surrounding rest-flow, diagnosed as deep venous thrombosis (DVT) (Figure 3). The femoral vein and calf veins were not affected.

\section{Discussion}

Thrombus formation in a superficial vein can lead to superficial thrombophlebitis. This complication of foam sclerotherapy has an incidence in the range 4.4-32\%.4,5 Superficial thrombophlebitis commonly resolves without specific therapy. If, however, treatment of superficial thrombophlebitis is administered, it mostly consists of anti-inflammatory drugs, such as aspirin or ibuprofen, which also help to relieve the pain. In addition, supportive compression hosiery can be applied. It can take from several days to weeks for the clot to resolve and for the symptoms to disappear completely.

Only seldom does superficial thrombophlebitis after foam sclerotherapy progress to a severe medical complication, as observed in our patient. Recently, Jia et al. ${ }^{6}$ reviewed 29 studies and showed that the median rate of serious adverse events, such as pulmonary embolism and deep venous thrombosis (DVT), was less than $1 \% .{ }^{5}$ This percentage is comparable with the incidences of DVT after surgical procedures and after different endovenous treatment regimens for varicose veins. Nevertheless, it is important to emphasize that, in patients with varicoses, the incidence of DVT is higher than that in the general population, and therefore a causal correlation with foam sclerotherapy may not even exist. ${ }^{7}$ Without doubt, however, there is a strong association of superficial thrombophlebitis with DVT, as the latter complication is significantly more frequently (6-44\%) observed in patients with a preceding diagnosis of superficial thrombophlebitis. ${ }^{8}$

Our patient initially developed a superficial thrombophlebitis in the arcus venosus superficialis dorsalis after foam sclerotherapy (Figs 1 and 2). Possibly, a part of the foam injected into the great saphenous vein (GSV) below the left knee ran in a retrograde direction towards the venous dorsal arch of the left foot and, eventually, progressed to DVT of the popliteal vein (Fig. 3). Another possibility is that a portion of the foam directly spread into a perforator vein and DVT commenced from there.

If serious complications occur after foam sclerotherapy, additional risk factors are likely to play a role. These include the use of high doses of foam, as well as the treatment of truncal saphenous or incompetent perforating veins. ${ }^{9}$ The individual presented here had been on postmenopausal hormone therapy for 6 months, and it is well known that treatment with ethinylestradiol/gestodene (Femodene ${ }^{\circ}$ ) is associated with an increased risk of DVT, 
in particular within the first year. Thus, the combination of superficial thrombophlebitis and hormone therapy, as observed in our patient, constitutes an even higher risk for the development of DVT.

Although a rare complication of foam sclerotherapy, DVT is one of the most serious. Therefore, we strongly believe that the occurrence of a superficial thrombophlebitis that is not located in the immediate vicinity of the treated vein constitutes an indication for repeat follow-up examinations by duplex sonography until phlebitis has resolved, in order to recognize disease progression and possible involvement of the deep venous system.

\section{Conflicts of interest}

The authors have declared no conflicts of interest.

\section{References}

1. Abbade L, Lastória S. Venous ulcer: epidemiology, physiopathology, diagnosis and treatment. Int J Dermatol 2005;44:449-456.

2. Rabe E, Otto J, Schliephake D, et al. Efficacy and safety of great saphenous vein sclerotherapy using standardised polidocanol foam (ESAF): a randomised controlled multicentre clinical trial. Eur J Vasc Endovasc Surg 2008;35:238-245.

3. Hamel-Desnos C, Desnos P, Wollmann JC, et al. Evaluation of the efficacy of polidocanol in the form of foam compared with liquid form in sclerotherapy of the greater saphenous vein: initial results. Dermatol Surg 2003;29:1170 -1175

4. Ceulen RP, Bullens-Goessens YI, Pi Vandevsj Nelemans PJ, et al. Outcomes and side effects of duplexguided sclerotherapy in the treatment of great saphenous veins with $1 \%$ versus $3 \%$ polidocanol foam: results of a randomized controlled trial with 1-year follow-up. Dermatol Surg 2007;33:276-281.

5. Jia X, Mowatt G, Burr JM, et al. Systematic review of foam sclerotherapy for varicose veins. Br J Surg 2007;94:925 -936.

6. Bohler K, Baldt M, Schuller-Petrovic S, et al. Varicose vein stripping - a prospective study of the thrombotic risk and the diagnostic significance of preoperative color coded duplex sonography. Thromb Haemost 1995;73: 597-600.

7. Guex JJ, Allaert FA, Gillet JL, et al. Immediate and midterm complications of sclerotherapy: report of a prospective multicenter registry of 12,173 sclerotherapy sessions. Dermatol Surg 2005;31:123 -128.

8. Wichers IM, Di Nisio M, Buller HR, et al. Treatment of superficial vein thrombosis to prevent deep vein thrombosis and pulmonary embolism: a systematic review. Haematologica 2005; 90: 672 -677.

9. Alos J, Carreno P, Lopez JA, et al. Efficacy and safety of sclerotherapy using polidocanol foam: a controlled clinical trial. Eur JVasc Endovasc Surg 2006;31:101-107. 




\section{Chapter 6}

\section{In vivo effects of foam sclerotherapy on coagulation}

N H Shadid, S K van der Velden, R van Oerle, H ten Cate, A Sommer and P Nelemans

Phlebology. 2013 Mar 27. [Epub ahead of print] 


\begin{abstract}
Objective: The aim of this study was to evaluate whether foam sclerotherapy (FS) induces changes in CAT (calibrated automated thrombinography) and other coagulation parameters which could indicate an increased risk of thrombotic events.
\end{abstract}

Methods: Blood samples from eight patients treated with FS were taken before treatment and 30 minutes, one and four hours and one week after treatment. CAT parameters (ETP1n, Peak1n, Lag time 1), thrombin antithrombin complexes (TAT), d-dimers, fibrinogen, Von Willebrand (vWf Ag) factor and platelet-derived microparticles (MIPAs) were measured.

Results: Significant changes over time for Peak1n, fibrinogen, d-dimers, vWfAg and TAT complexes were observed. CAT parameters decreased over time, except for Lag time 1. D-dimers and TAT complexes increased and fibrinogen, vWf Ag, MIPA's decreased during the first hours.

Conclusion: The findings in this study support the hypothesis that FS initiate coagulation pathways, but there is no evidence that this activation results in an increased thrombosis risk. 


\section{Introduction}

Foam sclerotherapy (FS) is a minimally invasive technique for the treatment of varicose veins. Next to other endovenous ablation techniques it is becoming more popular due to the demand for minimally invasive and less expensive procedures. ${ }^{1-3}$ FS seems to be an effective and safe therapy in treating venous insufficiency. ${ }^{4,5}$ The aim of FS is to obliterate the lumen of the incompetent varicose vein. Successfully treated veins are transformed into fibrous cords and the functional result corresponds to surgical removal of a varicose vein. ${ }^{6}$

By inducing vessel wall injury, detergent sclerosants might be expected to initiate the same coagulation pathways that ultimately lead to the generation of thrombin and formation of a fibrin clot.7 The risk of postsclerotherapy deep venous thrombosis (DVT) is approximately $1 \%$. The fact that FS can induce a hypercoagulable state and that some patients may be at an increased risk of thrombotic events remains a concern for each specialist. ${ }^{5}$

Recently, Parsi et al. studied the in vitro effects of polidocanol on the coagulation system. They showed that whereas high concentrations of polidocanol achieve some anticoagulant activity, low concentrations induce the release of procoagulant plateletderived microparticles. ${ }^{8}$ Furthermore they demonstrated the clot kinetics of sclerosants by thromboelastography: strong clots were initiated at low concentrations and clot formation was prevented at higher concentrations. ${ }^{9}$ Hamel-Desnos et al. ${ }^{10}$ assessed the consequences of FS in vivo, showing that FS made from polidocanol had only a minimal effect on peripheral blood. Fabi et al. ${ }^{11}$ reported that foam made from sodium tetradecyl sulphate (STS) does not affect coagulation parameters.

Thrombin is central to the coagulation process, but classical clotting tests, such as the activated partial thromboplastin time and prothrombin time assess only time to initiation of clot formation and do not reflect thrombin generation. In vitro, more than $95 \%$ of thrombin generation occurs after the initial formation of fibrin, which means that traditional coagulation tests account for less than $5 \%$ of the overall thrombin potential. Calibrated Automated Thrombography (CAT) measures the activity of free thrombin and enables a continuous measurement of thrombin generation in plasma. ${ }^{12,13}$

It has been hypothesized that major parameters of the resulting thrombogram, such as endogenous thrombin potential (ETP) and peak height (Peak) correlate with hypercoagulable states and increased risk of thrombotic events. ${ }^{12}$ The objective in this pilot study is to evaluate whether FS induces changes in coagulation parameters compared with baseline that could indicate an increased risk of thrombotic events as measured by CAT. To the best of our knowledge this test has never been used in the setting of sclerosants. The effects observed 
in this global assay were further analysed using selected determinants of hemostasis and activated clotting, including thrombin antithrombin complexes (TAT), d-dimers, fibrinogen, Von Willebrand (vWf Ag) factor and platelet-derived microparticles (MIPAs).

\section{Methods}

\section{Study subjects}

Patients with varicose veins were recruited at the outpatient clinic of Dermatology. Patients were eligible if they were scheduled for foamsclerotherapy of the great saphenous vein, small saphenous vein or anterior accessory saphenous veins. Subjects were excluded if they had a history of coagulation disorders or thromboembolic processes, used anticoagulation or antiplatelet medication, were pregnant at the time of the treatment, had signs of DVT on venous ultrasound, suffered from immobility or had a short life-expectancy.

After informed consent was obtained, eight patients were included and were all treated with foamsclerotherapy. The polidocanol (3\% Aethoxysklerol ${ }^{\circledR}$, Kreussler Pharma, Wiesbaden, Germany) was prepared using the Tessari's method in a standard ratio of $1 \mathrm{~mL}$ of liquid and $4 \mathrm{~mL}$ of room air. ${ }^{14}$

Subsequently, the foam was directly injected in the affected vein using an 18 gauge venflon (B Braun Melsungen, Germany). The treatment was performed by an experienced physician. All patients received elastic compression during a period of four weeks, exerting at least a $23 \mathrm{mmHg}$ ankle pressure ( $23 \mathrm{mmHg}$ Mediven Plus).

The study was approved by the medical ethics committee of Maastricht University Medical Centre. Informed consent was provided from all patients before participating in the study, according to the principles of the Declaration of Helsinki.

\section{Blood and plasma collection}

Blood samples were taken from each subject at baseline, 30 minutes, one hour, four hours and one week after treatment with foam sclerotherapy. This time points were chosen based with the hypothesis that because of short half times the most substantial changes in coagulation parameters can be expected within the first hours after foam sclerotherapy. Parameters were also measured at one week after treatment to observe whether at that time point parameters have returned back to baseline levels. Citrated samples were obtained through antecubital venipuncture for five times, at the same site. (1 volume trisodium citrate $0.105 \mathrm{~mol} / \mathrm{L}$ to 9 volumes blood). A tourniquet was used to better visualize the vein, after 
puncture the tourniquet was removed and $4 \mathrm{~mL}$ of blood was flushed before the citrated plasma was collected. Plasma was separated from the cells through centrifugation at 1750 $\mathrm{g}$ for 15 minutes at room temperature. Platelet poor plasma (PPP) was prepared by a second plasma centrifugation step at $10,000 \mathrm{~g}$ for 10 minutes at room temperature. Samples were frozen at $-80 \mathrm{C}$.

We measured CAT parameters (ETP, Peak and Lag time) and the following coagulation parameters; thrombin antithrombin complexes (TAT), d-dimers, fibrinogen, Von Willebrand (vWf Ag) factor and platelet-derived microparticles (MIPAs).

\section{Calibrated Automated Thrombogram (CAT)}

CAT was performed by using a 96-well plate fluorescent reader and standard CAT reagents supplied by Thrombinoscope (Synapse BV, Maastricht, The Netherlands). Parameters of interest were lag time, which was defined as the time to initial thrombin formation in minutes, the ETP, which is the area-under-the-curve representing the presence of thrombin in time and peak height (Peak), representing the maximal concentration of thrombin formed in plasma in (nmol/L). ${ }^{15}$ Peak height values were calculated as a percentage of normal (Peak1n\%). Normal Peak1n\% values have a range between $60-170 \%$.

ETP was triggered by the addition of $20 \mu \mathrm{L}$ tissue factor, final concentration $1 \mathrm{pmol} / \mathrm{L}$, phospholipids ( $4 \mu \mathrm{mol} / \mathrm{L}$ ) and calcium ions to $80 \mu \mathrm{L}$ of PPP.

Thrombin generation parameters were calculated with standard thrombinoscope ${ }^{\circledast}$ software program (version 2.2). ETP values are given as thrombin activity throughout the time (nmol/L min). Subsequently ETP values were calculated as a percentage of normal (ETP1n\%). Normalized values were calculated as patients values divided by mean values from normal pool plasma multiplied by $100 \%$. Normal ETP1 $\mathrm{n} \%$ values have a range between 60 and $170 \% .^{16}$

\section{Other coagulation parameters}

TAT complexes and d-dimers provide information about the acute phase of coagulation. TAT and $d$-dimers are both measured using enzygnost ${ }^{\oplus}$ (Siemens) and innovance-d-dimer (CA7000, Siemens) respectively. The normal values forTAT are below $4.0 \mathrm{mg} / \mathrm{mL}$ and $<500 \mathrm{ng} /$ $\mathrm{mL}$ for d-dimers. Fibrinogen was measured according to the Clauss method (Siemens) with normal values between 1.7 and $3.5 \mathrm{~g} / \mathrm{L} .{ }^{17} \mathrm{vWf} \mathrm{Ag}$ is a marker for endothelial damage and was measured using standard reagent (Siemens). ${ }^{18}$ Normal values have a range between $60 \%$ and $160 \%$ (internal assay validation calibrated against World Health Organization standard plasma). The MIPAs were measured using the ZYMUPHEN MP-activity kit (Hyphen Biomed). Values below $10 \mathrm{nmol} / \mathrm{L}$ equivalent phosphatidylserine were considered as normal. 


\section{Study endpoints}

The primary endpoint is the change of the ETP over time based on the assumption that this test best reflects overall coagulation activation status.

Secondary outcomes are changes over time of other coagulation markers and factors, such TAT complexes, d-dimers, fibrinogen, vWf Ag and the activity of MIPAs.

\section{Statistical analysis}

Median values for parameters over time were plotted in a graph. Median values were used because of the small sample size values which are not normally distributed. Differences between median values at different time points were tested using a non-parametic test for paired samples (Friedman test). The difference of each value compared with baseline was tested using the Wilcoxon test. $P$ values $\leq 0.05$ were considered to indicate statistical significance. Analyses were performed using SPSS 15.0 for Windows.

\section{Results}

Eight patients were included. The average age was 51.1 \pm 9.4 years (range $38-69$ years). Seven patients were primarily affected, including three great saphenous veins (38\%), four accessorial lateral saphenous veins (50\%) and one recurrent great saphenous vein (13\%). The amount of foam injected ranged from 4 to $9 \mathrm{~mL}$. Baseline characteristics are presented in Table 1.

Table 1. Baseline characteristics of eight patients treated with foam sclerotherapy

\begin{tabular}{l|l}
\hline Baseline characteristics & \\
\hline $\begin{array}{l}\text { Age (years) } \\
\text { Female }\end{array}$ & $52.8($ SD 9.8) (range 50 - 69) \\
\hline $\begin{array}{l}\text { Clinical presentation } \\
\text { C2 }\end{array}$ & $5(62 \%)$ \\
\hline C3 & $3(37.5 \%)$ \\
\hline $\begin{array}{l}\text { Type of vein } \\
\text { GSV }\end{array}$ & $3(37.5 \%)$ \\
\hline $\begin{array}{l}\text { Tributary } \\
\text { Recurrent GSV }\end{array}$ & $4(50 \%)$ \\
\hline $\begin{array}{l}\text { Volume of foam (cc) } \\
\text { GSV, great saphenous vein; SD, standard deviation }\end{array}$ & $1(12.5 \%)$ \\
\hline
\end{tabular}




\section{Effect on CAT parameters and other coagulation parameters}

Median values were calculated at different time points for each individual coagulation parameter (see Table 2). With respect to the CAT parameters median values decreased over time except for Lag time 1. ETP reached the lowest value at four hours (135\%). Peak significantly changed over time $(P=0.014)$ and reached a nadir at four hours $(169 \%)$ (Table 2 , Figure 1). Furthermore we detected significant changes for the following coagulation parameters; fibrinogen, d-dimers, vWf Ag and TAT complexes. Median value for fibrinogen at baseline was $3.6 \mathrm{~g} / \mathrm{L}$ and decreased to $3.25 \mathrm{~g} / \mathrm{L}$ at four hours and thereafter it increased to $3.7 \mathrm{~g} / \mathrm{L}$ at one week $(P=0.011)$. For the d-dimers an increase was observed from $525 \mathrm{ng} /$ $\mathrm{mL}$ at baseline to $1021 \mathrm{ng} / \mathrm{mL}$ at four hours and then concentrations decreased to $691 \mathrm{ng} /$ $\mathrm{mL}(\mathrm{P}=0.001)$. For $\mathrm{vWf} \mathrm{Ag}$ the following values were observed: $111 \%, 106 \%, 107 \%, 104 \%$ and $112 \%(P=0.005)$ and for TAT complexes values of $1.83 \mu \mathrm{g} / \mathrm{L}, 2.47 \mu \mathrm{g} / \mathrm{L}, 4.38 \mu \mathrm{g} / \mathrm{L}, 2.41$ $\mu \mathrm{g} / \mathrm{L}, 2.14 \mathrm{mg} / \mathrm{L}(\mathrm{P}=0.009)$ were seen. Fibrinogen was decreasing over time and the nadir was reached at four hours. The concentration of MIPA's showed a slightly increase over time and reached a peak at one week $(7.18 \mathrm{nmol} / \mathrm{L})$ (Table 2, Figure 2).

Table 2. Median values of CAT and other coagulation parameters. Differences between median values at different time points were tested using a non-parametric test for paired samples (Friedman test).Difference of each value compared to baseline was tested using the Wilcoxontest. P-values $\leq 0.05$ are indicated with *

\begin{tabular}{|c|c|c|c|c|c|c|}
\hline & At baseline & At $30 \mathrm{~min}$ & At 1 hour & At 4 hours & At 1 week & p-value \\
\hline $\begin{array}{l}\text { ETP } \\
\text { (nM.min) }\end{array}$ & $\begin{array}{c}158 \\
(123.3-190.2)\end{array}$ & $\begin{array}{c}146 \\
(113.9-173.5)\end{array}$ & $\begin{array}{c}138 \\
(122.5-191.5)\end{array}$ & $\begin{array}{c}135 \\
(106.8-191.6)\end{array}$ & $\begin{array}{c}138^{*} \\
(119.3-199.8)\end{array}$ & 0.126 \\
\hline $\begin{array}{l}\text { Peak } \\
\text { (nM) }\end{array}$ & $\begin{array}{c}243 \\
(169.1-325.3)\end{array}$ & $\begin{array}{c}203^{*} \\
(110.4-260.0)\end{array}$ & $\begin{array}{c}200 \\
(134.3-256.3)\end{array}$ & $\begin{array}{c}169^{*} \\
(123.3-275.7)\end{array}$ & $\begin{array}{c}186^{*} \\
(157.6-294.7)\end{array}$ & 0.014 \\
\hline $\begin{array}{l}\text { Lag time } \\
\text { (Min) }\end{array}$ & $\begin{array}{c}5.46 \\
(4.30-7.33)\end{array}$ & $\begin{array}{c}5.99 * \\
(4.50-8.00)\end{array}$ & $\begin{array}{c}5.90 \\
(4.33-7.67)\end{array}$ & $\begin{array}{c}6.00 * \\
(4.60-7.64)\end{array}$ & $\begin{array}{c}6.06 \\
(4.94-9.31)\end{array}$ & 0.10 \\
\hline $\begin{array}{l}\text { Fibrinogen } \\
(1.7-3.5 \mathrm{~g} / \mathrm{l})\end{array}$ & $\begin{array}{c}3.6 \\
(2.4-4.0)\end{array}$ & $\begin{array}{c}3.30 \\
(2.4-4.1)\end{array}$ & $\begin{array}{c}3.30^{*} \\
(2.4-4.0)\end{array}$ & $\begin{array}{c}3.25^{*} \\
(2.3-3.9)\end{array}$ & $\begin{array}{c}3.7 \\
(2.4-4.1)\end{array}$ & 0.011 \\
\hline $\begin{array}{l}\text { D-dimers } \\
(<500 \mathrm{ng} / \mathrm{ml})\end{array}$ & $\begin{array}{c}525^{*} \\
(189-1187)\end{array}$ & $\begin{array}{c}719^{*} \\
(371-3200)\end{array}$ & $\begin{array}{c}800^{*} \\
(352-3773)\end{array}$ & $\begin{array}{c}1021^{*} \\
(491-4046)\end{array}$ & $\begin{array}{c}691^{*} \\
(323-9222)\end{array}$ & 0.001 \\
\hline $\begin{array}{l}\text { vWf Ag } \\
(60-160 \%)\end{array}$ & $\begin{array}{c}111 \\
(79.2-158.8)\end{array}$ & $\begin{array}{c}106 \\
(78.7-154.7)\end{array}$ & $\begin{array}{c}107 \\
(79.3-147.9)\end{array}$ & $\begin{array}{c}104^{*} \\
(74.4-143.6)\end{array}$ & $\begin{array}{c}112 \\
(74.8-159.3)\end{array}$ & 0.005 \\
\hline $\begin{array}{l}\text { TAT complexes } \\
(<4.0 \mathrm{~g} / \mathbf{m l})\end{array}$ & $\begin{array}{c}1.83 \\
(1.3-7.1)\end{array}$ & $\begin{array}{c}2.47 \\
(1.9-16.9)\end{array}$ & $\begin{array}{c}4.38^{*} \\
(2.3-11.2)\end{array}$ & $\begin{array}{c}2.41 \\
(1.9-7.7)\end{array}$ & $\begin{array}{c}2.14 \\
(0.9-14.0)\end{array}$ & 0.009 \\
\hline $\begin{array}{l}\text { MIPA's } \\
(<10 \mathrm{nM})\end{array}$ & $\begin{array}{c}5.33 \\
(4.5-8.8)\end{array}$ & $\begin{array}{c}6.66 \\
(3.0-10.5)\end{array}$ & $\begin{array}{c}6.67 \\
(4.4-9.5)\end{array}$ & $\begin{array}{c}6.46 \\
(4.0-32.9)\end{array}$ & $\begin{array}{c}7.18^{*} \\
(4.9-20.9)\end{array}$ & 0.165 \\
\hline
\end{tabular}




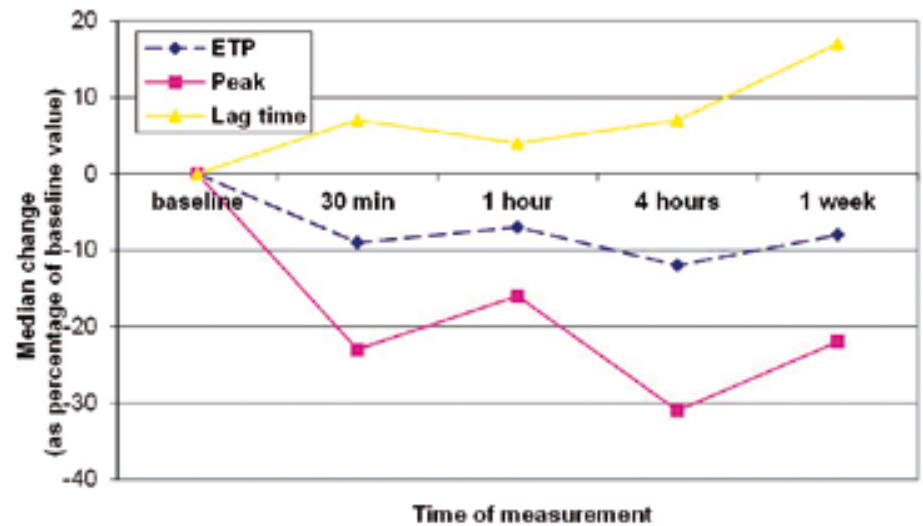

Figure 1. Median changes in CAT parameters over time

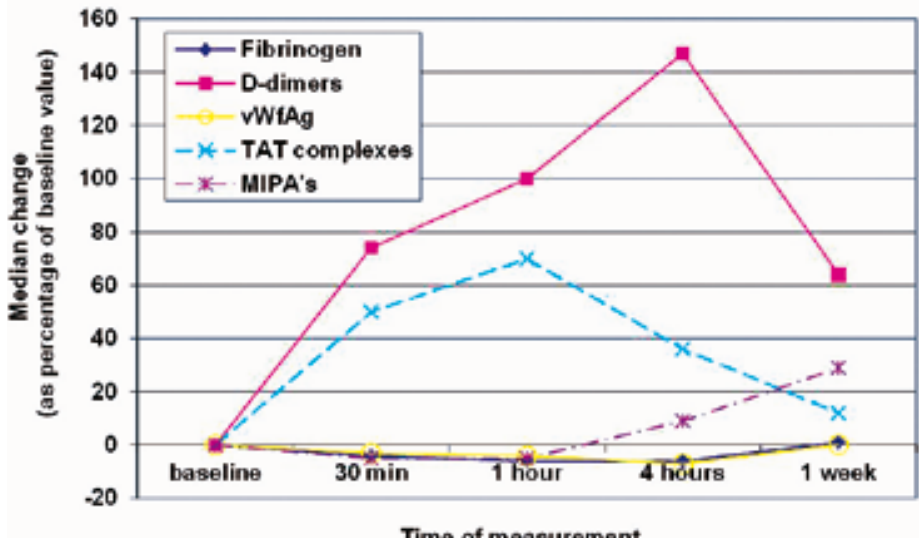

Figure 2. Median changes in coagulation parameters over time 


\section{Discussion}

The main finding in this pilot study is that FS causes a marked and acute activation of the coagulation system, illustrated by time-dependent rises in d-dimer and TAT levels, indicative of acute thrombin and fibrin formation and digestion, respectively. At the same time, the ETP1n and Peak1n decreased slightly over time. These changes in CAT parameters are suggestive of a compensatory mechanism that may have an inhibitory effect on the potential to generate thrombin. This divergent reaction may imply that in spite of an acute procoagulant effect of the sclerosing agent, the tendency to thrombosis (hypercoagulability) may be dampened by this, unknown, compensatory mechanism.

Usually high ETP1n values (reflecting the thrombin generation) are predictive for an increased risk of venous thrombosis. ${ }^{12,19}$ Thus, the absence of such rises upon sclerotherapy also argues against a major thrombosis risk. The lack of major changes in $\mathrm{vWf} A g$ and fibrinogen reflect a lack of activation of vascular endothelium and inflammation, respectively, during the course of this local treatment. Obviously, any local effects on the vascular endothelium are diluted in the systemic circulation and will escape measurement in the venous sample collected. The MIPAs show an interesting pattern with a late rise, which in the absence of concurrent procoagulant effects may reflect cell death secondary to sclerosis treatment.

Two other studies has reported on the in vivo biological effects of the treatment of FS. Hamel-Desnos et al. ${ }^{10}$ concluded that FS has a minimal effect on coagulation measured in peripheral blood. Fabi et al. ${ }^{11}$ showed that foam made from STS does not affect coagulation parameters as measured according to platelet count and concentrations of clotting factors and fibrinogen. These studies lead to similar conclusions, despite some differences in design. Like Hamel-Desnos we measured fibrinogen, vWf Ag, TAT-complexes and d-dimers. In addition we measured MIPA's which are markers for the activation of thrombocytes, endothelial cells and leukocytes. We also added CAT parameters which were used as a quantitative measure of the thrombin-forming capacity in plasma samples. In this way, we were able to assess the overall hypercoaguability potential. Furthermore, the sampling schedule was different. In the study by Hamel-Desnos, laboratory work-up was done on days 1, 7, 14 and 28 after FS. In the study of Fabi et al. venous blood was drawn before treatment and 15 minutes after treatment. We measured parameters within a couple of hours after treatment with foam, as we hypothesized that because of short half times the most substantial changes in coagulation parameters would be expected within the first hours after FS. Parameters were also measured at one week after treatment to observe whether at that time point parameters have returned back to baseline levels. 
Except for the studies of Hamel-Desnos and Fabi, we did not find any other studies reporting on the effect of FS on coagulation parameters. However, some publications have reported on the effect of liquid sclerosants on coagulation. ${ }^{20-22}$

Mason et al. revealed a significant conversion from negative to positive d-dimers levels in patients after sclerotherapy of vascular anomalies. However, the sclerosant that was used was not polidocanol but sodium tetradecyl sulphate or dehydrated alcohol.21 Bernardi et al. ${ }^{22}$ reported a small reduction of prothrombin and antithrombin activity in patients with abnormal coagulation function due to liver cirrhosis who were treated for oesophageal varices with slcerotherapy, but these changes did not lead to clinically significant deterioration of coagulation. In addition, Suzuki et al. ${ }^{20}$ reported a small decrease of platelet levels after 15 minutes of polidocanol injection in mongrel dogs. Parsi et al. showed that polidocanol in vitro caused a mild reduction in Protein $\mathrm{C}$ and antithrombin and a moderate reduction in Protein S levels.

The results of the above mentioned studies as well as our study suggest that neither liquid sclerotherapy nor FS strongly affect the haemostatic system. The observed minimal changes in coagulation parameters correspond with the clinical observation that venous thrombolic events (VTE) after FS occur in only a small number of cases. The estimated rate of pulmonary embolism and DVT was less than 1\% after FS in a metaanalysis. ${ }^{23,24}$ The decrease of ETP1n possibly indicates a compensatory mechanism and may explain the finding that venous thrombolic events are observed in only a low percentage of patients.

Limitations of this study are the small sample size, the lack of a control group and lack of standardization of foam treatment regarding volume.

In conclusion, the findings in this study support the hypothesis that FS initiate coagulation pathways, but provide no evidence that this activation results in a hypercoagulable state in peripheral blood after treatment, at least in patients without apparent thrombophilic defects.

\section{Acknowledgements}

The laboratory tests were funded through the 'Pieken in de Breedte' program of the Maastricht University Medical Center+. There is no conflict of interest to report. 


\section{References}

1. Beale RJ, Gough MJ. Treatment options for primary varicose veins - a review. Eur J Vasc Endovasc Surg 2005;30:83-95

2. Teruya TH, Ballard JL. New approaches for the treat- ment of varicose veins. Surg Clin North Am 2004; 84:1397 - 417, viii - ix

3. Darvall KA, Bate GR, Adam DJ, Bradbury AW. Recovery after ultrasound-guided foam sclerotherapy compared with conventional surgery for varicose veins. Br J Surg 2009;96:1262 - 7

4. Myers KA, Jolley D, Clough A, Kirwan J. Outcome of ultrasound-guided sclerotherapy for varicose veins: medium-term results assessed by ultrasound surveil- lance. Eur JVasc Endovasc Surg 2007;33:116 - 21

5. Gillet JL, Guedes JM, Guex JJ, et al. Side-effects and complications of foam sclerotherapy of the great and small saphenous veins: a controlled multicentre prospective study including 1025 patients. Phlebology 2009;24:131-8

6. Rabe E P-FF, Gerlach H. Leitlinien zur Verodungsbehan- dlung der Varikose (ICD 10: 183.0, 183.1, 183.2, 183.9) entwicklungsstufe 1. Phlebologie 30:154-8

7. Kern P. Sclerotherapy of varicose leg veins. Technique, indications and complications. Int Angiol 2002; 21(Suppl. 1):40 - 5

8. Parsi K, Exner T, Connor DE, Ma DD, Joseph JE. In vitro effects of detergent sclerosants on coagulation, platelets and microparticles. Eur J Vasc Endovasc Surg 2007;34:731 - 40

9. Parsi K, Exner T, Low J, Fung Ma DD, Joseph JE. In vitro effects of detergent sclerosants on clot formation and fibrinolysis. Eur J Vasc Endovasc Surg 2011;41:267 - 77

10. Hamel-Desnos CM, Desnos PR, Ferre B, Le Querrec A. In vivo biological effects of foam sclerotherapy. Eur J Vasc Endovasc Surg 2011;42:238 - 45

11. Fabi SG, Peterson JD, Goldman MP, Guiha I. An investi- gation of coagulation cascade activation and induction of fibrinolysis using foam sclerotherapy of reticular veins. Dermatol Surg 2012;38:367 - 72

12. Adams M. Assessment of thrombin generation: useful or hype? Semin Thromb Hemost 2009;35:104 - 10

13. Luddington R, Baglin T. Clinical measurement of throm- bin generation by calibrated automated thrombography requires contact factor inhibition. J Thromb Haemost 2004;2:1954- 9

14. Tessari L, Cavezzi A, Frullini A. Preliminary experience with a new sclerosing foam in the treatment of varicose veins. Dermatol Surg 2001;27:58 - 60

15. Hemker HC, Beguin S. Thrombin generation in plasma: its assessment via the endogenous thrombin potential. Thromb Haemost 1995;74:134 - 8

16. Spronk HM, Dielis AW, De Smedt E, et al. Assessment of thrombin generation II: validation of the calibrated auto- mated thrombogram in platelet-poor plasma in a clinical laboratory. Thromb Haemost 2008;100: $362-4$

17. Clauss A. Rapid physiological coagulation method in determination of fibrinogen. Acta Haematol 1957;17:237- 46

18. Lip GY, Blann A. von Willebrand factor: a marker of endothelial dysfunction in vascular disorders? Cardiovasc Res 1997;34:255 - 65

19. Ten Cate H. Thrombin generation in clinical conditions. Thromb Res 2012;129:367 - 70

20. Suzuki N, Nakao A, Nonami T, Takagi H. Experimental study on the effects of sclerosants for esophageal varices on blood coagulation, fibrinolysis and systemic hemodynamics. Gastroenterol Jpn 1992;27:309- 16

21. Mason KP, Neufeld EJ, Karian VE, Zurakowski D, Koka BV, Burrows PE. Coagulation abnormalities in pediatric and adult patients after sclerotherapy or embolization of vascular anomalies. AJR Am J Roentgenol 2001; 177:1359-63

22. Bernardi M, Palareti G, Pini P, Caletti GC, Brocchi E Gasbarrini G. Study on coagulation profile of patients with cirrhosis of the liver undergoing elective fibreoptic injection sclerotherapy of oesophageal varices. Hepatogastroenterology 1984;31:125-8

23. Jia X, Mowatt G, Burr JM, Cassar K, Cook J, Fraser C. Systematic review of foam sclerotherapy for varicose veins. Br J Surg 2007;94:925 - 36

24. Rathbun S, Norris A, Stoner J. Efficacy and safety of endovenous foam sclerotherapy: meta-analysis for treatment of venous disorders. Phlebology 2012 

Chapter 7

\title{
Predictors of recurrence of great saphenous vein reflux following
} treatment with ultrasound-guided foamsclerotherapy

\author{
N. Shadid, P. Nelemans, J. Lawson, A.Sommer
}

Submitted to Phlebology 


\section{Abstract}

Objective: To investigate which clinical characteristics at baseline are predictive for great saphenous vein recurrence following ultrasound-guided foamsclerotherapy (UGFS).

Material and Methods: Data of patients treated for GSV incompetence with UGFS were derived from a multicentre prospective randomised controlled trial comparing surgery versus UGFS with a follow-up of 2-years. Recurrence of reflux was determined on colour duplex scans at 3, months, 1 year and 2 years. Univariate and multivariate Cox regression analysis was used to evaluate the effect of gender, age, $C$ of CEAP classification, diameter of GSV, injected foam volume, presence of distal GSV reflux, presence of reflux in the anterior accessory saphenous vein (AASV) and Venous Clinical Severity Score (VCSS) on risk of recurrent reflux.

Results: 225 patients were available for analysis. Treatment after one single session was successful in 120 patients and recurrence of saphenous reflux was observed in 105 patients within 2 years during follow-up. Significant associations with risk of recurrence were observed for mid thigh GSV diameter ( $\mathrm{HR}=1.012$ with $95 \% \mathrm{Cl}: 1.002-1.022, \mathrm{p}=0.022)$, presence of distal GSV reflux ( $\mathrm{HR}=1.882$ with $95 \% \mathrm{Cl}: 1.029-3.443, \mathrm{p}=0.040)$ and presence of C4-C5 (HR=1.509 with 95\% Cl: 0.882-2.583, $\mathrm{p}=0.134)$.

Conclusion: In conclusion, this prospective study suggests that UGFS treatment for the proximal GSV is less effective for patients with a large vein, a refluxing distal GSV and C4-C5 at baseline. 


\section{Introduction}

Lower extremity venous insufficiency is a common health problem in Western countries, and its prevalence increases with age. The disease has a substantial impact on patients' quality of life, as well as on the resources and budgets of health care systems ${ }^{1}$. Insufficiency of the great saphenous vein (GSV) is the most common cause of varicose veins of the lower extremity and of leg ulcer development ${ }^{2}$. For many years the standard treatment was surgical stripping of the GSV. However, in recent years a variety of minimally invasive and less expensive procedures have been used with increasing frequency ${ }^{3}$. One of these techniques is ultrasound-guided foamsclerotherapy (UGFS), which is effective, low in costs, easy to perform and can be used for different varicose veins, such as primary varicose veins, tortuous veins, tributaries and recurrences ${ }^{4-6}$.

A recently published randomized controlled trial has shown that UGFS is a cost-effective alternative to surgical stripping ${ }^{5}$. The protocol in the published trial allowed extra UGFS sessions if a recurrent reflux in combination with persistent venous symptoms occurred during follow-up. Two years after treatment, the probability of clinically relevant recurrence (with presence of symptoms) was similar in the UGFS and surgery groups, but failure to eliminate GSV failure was observed in $35 \%$ of patients treated by UGFS compared to $21 \%$ in the surgery group. It can be argued that recurrent reflux alone without symptoms has minor clinical relevance, but there is also concern that anatomic recurrence may predispose to recurrent veins developing in the future ${ }^{7}$. For this reason, the aim of the present study was to identify patient and treatment characteristics that influence the probability of anatomic recurrence of reflux of the GSV after treatment by UGFS. Effectiveness might be improved by better patient selection and more tailored treatment.

\section{Methods}

\section{Patients}

Data were derived from a multicentre randomized controlled trial comparing surgery to UGFS in treating primary GSV incompetence with a follow-up of two years. The study design and procedures have been described before ${ }^{8}$. Consecutive patients referred for treatment of symptomatic varicose veins by general practitioners were recruited at the outpatient dermatology and surgery departments of three hospitals in the southern part of the Netherlands. Eligible were patients with a primary GSV incompetence and one or more venous symptoms. An incompetent GSV was defined as reflux $>0.5 \mathrm{~s}$ in the saphenofemoral junction and GSV (measured over a distance of at least $20 \mathrm{~cm}$ in the upper leg). 
Patients with an incompetent deep venous system, signs of a previous deep venous thrombosis on duplex imaging, an active ulcer or a contraindication to the use of polidocanol were excluded. The trial was approved by the medical ethics committee of Maastricht University Medical Centre. All patients provided written informed consent before participating in the study, according to the principles of the "Declaration of Helsinki".

\section{UGFS treatment}

The GSV was identified by duplex imaging in the standing position and marked from the groin following the path of reflux in the GSV. Sclerosing foam was prepared with the double-syringe technique, applying a $1: 4$ ratio of sclerosant : air. One syringe was filled with $1 \mathrm{ml}$ of 3 per cent polidocanol (Aethoxysklerol ${ }^{\circledR}$; Kreussler Pharma, Wiesbaden, Germany) and the other syringe with $4 \mathrm{ml}$ air. Patients were treated in supine position with an 18Fr intravenous cannula (B. Braun, Melsungen, Germany), under direct duplex imaging. The cannula was inserted just above the knee. The treatment was considered successful when the proximal GSV was completely filled with foam and maximal venospasm was achieved. Initially, only the GSV trunk was treated with the hypothesis that refluxing tributaries may go into regression. If reflux in large superficial tributaries was present, shortly after the first visit, these tributaries were treated by phlebectomies. Treatment with UGFS or phlebectomy of refluxing smaller tributaries or small saphenous veins was performed at the planned follow-up visits. Compression was applied with a foampad over the treated area and an antiembolism (Brevet TX $10 \mathrm{mmHg}$ ) stocking for one week, day and night. Elevation of the leg or compression of the saphenofemoral junction was not applied. A Class II elastic stocking (23 $\mathrm{mmHg}$ Mediven Plus) was prescribed during daytime for six weeks. After treatment, patients were instructed to walk for at least 30 minutes, after which they could resume their daily activities, including professional activities.

\section{Data collection}

Information was available on patient characteristics such as gender and age, clinical presentation (C of CEAP classification) and disease extent and severity at baseline. A Venous Clinical Severity Score (VCSS) was assigned by the research physician. Presence or absence of reflux in both the anterior accessory saphenous vein (AASV) and the distal GSV were registered. The diameter of the GSV at baseline was recorded at different levels: upper thigh, mid thigh and lower thigh. The diameter was measured in upright position with transversal view and the maximum diameter was taken in consideration. After treatment the volume of injected foam was noted and duplex examination of the GSV was performed at 3,12 and 24 months. Recurrent reflux $>0.5 \mathrm{~s}$ was defined as reflux of more than $2 \mathrm{~cm}$ in length in the treated vein segment (proximal GSV) as measured by colour flow Doppler ultrasonography. Recurrence of reflux was defined in this study as anatomic recurrence of reflux irrespective of whether the patient reported recurrence of venous symptoms or not. 


\section{Statistical analysis}

Patients with and without anatomic recurrence of reflux were compared with respect to patient and treatment characteristics. Categorical variables were expressed as percentages and absolute numbers. Continuous variables were expressed as mean values with standard deviation (sd) for variables with a normal distribution or median values with range for variables without a normal distribution. Between- group comparisons were performed using the t-test for independent samples if variables were normally distributed or the nonparametric Wilcoxon test for not normally distributed data and the Chi-square test for categorical data.

To evaluate the association of clinical characteristics with the risk of recurrence of saphenous reflux, univariate and multivariate Cox regression analyses were performed with presence or absence of reflux as the dependent variable. Patients were censored at the time of a first recurrence.

Variables associated with $\mathrm{p}$-values $<0.15$ from univariate analysis were considered as potentially relevant predictors for treatment failure and were simultaneously entered in a multivariate Cox regression model to evaluate the independent effects on treatment failure. The magnitude of effect was expressed by hazard ratios (HR) with $95 \%$ confidence intervals $(\mathrm{Cl})$. For initial selection of potential predictors, $\mathrm{p}$-values $<0.15$ were considered to indicate statistical significance, because $p$-values $\leq 0.05$ may be too strict and result in missing identification of relevant variables ${ }^{9}$. Based on the identified predictors of recurrent saphenous reflux patients were categorized into subgroups. Kaplan-Meier survival analysis was used to calculate the observed cumulative probabilities of recurrence free survival with $95 \%$ confidence intervals within subgroups of patients.

All data were analysed using SPSS version 18.0 (SPSS, Chicago, IL, USA and STATA, version 11.2).

\section{Results}

Data of 225 patients treated by UGFS were available for investigation. Treatment after one single session was successful in 120 patients and treatment failure was observed in 105 patients within 2 years during follow-up. Table 1 shows the distribution of baseline clinical characteristics for patients with and without recurrence of saphenous reflux.

Hazard ratios (HR) with 95\% Cl from univariate analysis for gender, age, clinical presentation (C of CEAP classification), diameter of GSV, volume of injected foam, presence of distal 
Table 1. Baseline characteristics (absolute numbers and proportions or median values with ranges).

\begin{tabular}{|c|c|c|c|}
\hline & Treatment failure $n=105$ & Treatment success $n=120$ & p-value \\
\hline Age(years) & $53.0(\mathrm{SD} 13.4)$ & 50.7 (SD 12.9) & 0.2 \\
\hline Female gender & $78 \quad(74.3 \%)$ & $90 \quad(75.0 \%)$ & 0.9 \\
\hline \multicolumn{4}{|l|}{ Clinical presentation } \\
\hline $\mathrm{C} 2$ & $84 \quad(80.0 \%)$ & $100(83.3 \%)$ & 0.16 \\
\hline $\mathrm{C} 3$ & $(4.8 \%)$ & $12 \quad(10 \%)$ & \\
\hline $\mathrm{C} 4$ & $13 \quad(12.4 \%)$ & $6 \quad(5.0 \%)$ & \\
\hline $\mathrm{C} 5$ & $3 \quad(2.9 \%)$ & $2 \quad(1.7 \%)$ & \\
\hline VCSS & $3.0 \quad(1-10)$ & $3.0 \quad(0-11)$ & 0.072 \\
\hline Diameter GSV upper thigh (mm) & 6.3 (SD 2.1) (2.4-15.4) & $5.6(S D$ 1.8) (2.3-11.9) & 0.009 \\
\hline Diameter GSV mid thigh $(\mathrm{mm})$ & 5.8 (SD 1.9) (1.5-13.6) & 5.1 (SD 1.5) (2.3-10.4) & 0.005 \\
\hline Diameter GSV low thigh(mm) & $5.3(S D 2.1) \quad(1.2-12.8)$ & 4.9 (SD 1.5) (2.2-10.3) & 0.10 \\
\hline AASV reflux & $16 \quad(15.2 \%)$ & $(10.0 \%)$ & 0.24 \\
\hline Distal GSV reflux & $(89 \%)$ & $(76.7 \%)$ & 0.02 \\
\hline Volume of injected foam(ml) & $5.2(\mathrm{SD} 2.7) \quad(0-20)$ & $5.0(\mathrm{SD} 2.0) \quad(0-10)$ & 0.62 \\
\hline
\end{tabular}

Table 2. Results from univariate and multivariate Cox regression analyses. Hazard ratios (HR) represent relative risk of recurrence.

\begin{tabular}{|c|c|c|c|c|}
\hline & \multicolumn{2}{|l|}{ Univariate analyses } & \multicolumn{2}{|c|}{ Multivariate analyses } \\
\hline & HR $(95 \% \mathrm{Cl})$ & p-value & HR $(95 \% \mathrm{Cl})$ & p-value \\
\hline Age & $1.006(0.992-1.02)$ & 0.408 & & \\
\hline Gender (female vs male) & $1.073(0.693-1.664)$ & 0.751 & & \\
\hline Upperthigh diameter (mm) & $1.011(1.002-1.019)$ & 0.016 & & \\
\hline Midthigh diameter (mm) & $1.014(1.004-1.024)$ & 0.007 & $1.012(1.002-1.022)$ & 0.022 \\
\hline Lowthigh diameter (mm) & $1.009(0.999-1.019)$ & 0.074 & & \\
\hline $\begin{array}{l}\text { CEAP classification } \\
\text { (C4-5 vs }(2-3)\end{array}$ & $1.595(0.936-2.716)$ & 0.086 & $1.509(0.882-2.583)$ & 0.134 \\
\hline VCSS & $1.062(0.972-1.160)$ & 0.186 & & \\
\hline AASV reflux & $1.215(0.714-2.069)$ & 0.473 & & \\
\hline Distal GSV reflux & $1.922(1.053-3.508)$ & 0.033 & $1.882(1.029-3.443)$ & 0.040 \\
\hline Foam Volume (cc) & $1.009(0.935-1.090)$ & 0.811 & & \\
\hline
\end{tabular}

Only variables with $\mathrm{p}$-values $<0.15$ were included in the multivariate regression analysis 
GSV reflux, presence of AASV reflux and VCSS at baseline are shown in Table 2. Diameter of the GSV at all three levels (upper thigh, mid thigh and lower thigh), presence of reflux in the distal GSV lower leg and CEAP classification (CEAP 4-5 compared to CEAP 2-3) were associated with increased 2-year risk of recurrent reflux. Diameter at mid thigh level showed the strongest association with risk of treatment failure and was entered into a multivariate Cox regression model together with presence of distal GSV reflux and CEAP classification. Diameters at the other levels were not entered in the multivariate model, because strong correlation between potential predictors can cause predictors to compete and make the selection of relevant predictors arbitrary. Results derived from the multivariate Cox regression model are also presented in table 2 . After mutual adjustment the diameter of the thigh as well as reflux of the distal GSV and C4-C5 remained predictive.

Patients were classified into subgroups according to presence and absence of mid thigh diameter $>6 \mathrm{~mm}$ and/or distal reflux (Table 3 ). Due to the low number of patients with CEAP 4-5 $(n=24)$ distinction between patients with CEAP 2-3 versus CEAP 4-5 within these subgroups would result in estimates with wide $95 \% \mathrm{Cl}$ and therefore these estimates are not presented. The use of a cut-off point of $6 \mathrm{~mm}$ for mid thigh diameter was based on the study of Myers et $\mathrm{al}^{10}$. The observed 2-year cumulative probabilities of recurrence free survival within the subgroups were calculated using Kaplan Meier survival analysis. In the subgroup with presence of reflux in distal GSV in combination with a diameter $>6 \mathrm{~mm}$, the observed 2-year cumulative probability of saphenous reflux recurrence after one session was $63.9 \%$ (95\% Cl: $51.9 \%-75.8 \%)$. In the subgroup with only one risk factor present the observed probability was $46.5 \%$ (95\% Cl: $38.2 \%-55.8 \%)$. When both risk factors were absent, the observed probability was $27.0 \%$ (95\% Cl: $15.4 \%-45.5 \%$ ) (Table 3 ).

Table 3. Observed 2-year cumulative probability of recurrence ( $95 \%$ confidence intervals) according to patient characteristics.

\begin{tabular}{|l|c|l|l|}
\hline & $\begin{array}{l}\text { Number of } \\
\text { patients }\end{array}$ & $\begin{array}{l}\text { Observed cumulative } \\
\text { probability of } \\
\text { recurrence free survival }\end{array}$ & $\begin{array}{l}\text { Observed cumulative } \\
\text { probability of } \\
\text { recurrence }\end{array}$ \\
\hline Mid thigh diameter<6 mmm & 154 & $58.0 \%(46.6 \%-65.4 \%)$ & $42.0 \%(34.6 \%-50.4 \%)$ \\
\hline Mid thigh diameter $\geq 6 \mathrm{mmm}$ & 70 & $37.4 \%(25.8 \%-48.9 \%)$ & $62.6 \%(51.2 \%-74.2 \%)$ \\
\hline Distal GSV reflux absent & 40 & $69.5 \%(52.5 \%-81.3 \%)$ & $30.5 \%(18.6 \%-47.5 \%)$ \\
\hline Distal GSV reflux present & 185 & $47.9 \%(40.3 \%-55.1 \%)$ & $52.1 \%(44.9 \%-59.6 \%)$ \\
\hline Both risk factors absent & 34 & $73.0 \%(54.5 \%-85.0 \%)$ & $27.0 \%(15.4 \%-45.5 \%)$ \\
\hline One risk factor present & 126 & $53.5 \%(44.2 \%-61.9 \%)$ & $46.5 \%(38.2 \%-55.8 \%)$ \\
\hline Both risk factors present & 64 & $36.1 \%(24.2 \%-48.2 \%)$ & $63.9 \%(51.9 \%-75.8 \%)$ \\
\hline
\end{tabular}




\section{Discussion}

The demand for minimally invasive techniques such as UGFS in the treatment of GSV has considerably increased over the last few years, so defining prognostic factors for recurrence after treatment could potentially be important in a selection of those patients who might benefit from UGFS treatment and refine treatment. This study showed that a larger diameter of the GSV and presence of distal GSV reflux at baseline are predictive of a higher 2-year risk of recurrence.

In the present study we report a higher percentage of reflux recurrence than in the original trial. We performed a primary failure analysis and considered every recurrence of reflux as a failure irrespective of success after retreatment whereas in the original randomised controlled trial the initial recurrence of reflux was not counted as a treatment failure (secondary failure analysis).

Two previous studies reported on covariates affecting treatment success of UGFS. In the study of Myers et al. a Cox regression analysis showed a worse primary success rate for patients less than 40 years old, small compared to great saphenous veins, veins greater than $6 \mathrm{~mm}$ diameter compared to veins smaller than $5 \mathrm{~mm}$, patients treated with liquid compared to UGFS and patients treated with volumes of sclerosant less than $12 \mathrm{ml}$ compared to volumes greater than $12 \mathrm{ml}^{10}$. In the study of Gonzalez-Zeh a $90 \%$ treatment success of UGFS was observed for veins with a diameter $<6.5 \mathrm{~mm}^{11}$. The finding that GSVs with a larger diameter have a higher probability of failure is in line with these results from literature. The findings provide evidence that in these patients there might be an indication for alternative options such as, endovenous laser ablation (ELVA), radiofrequency ablation (RFA) or surgery.

Another important finding in this study is that distal GSV and a higher C of the CEAP classification is a predictor of recurrent reflux. It seems that a more extended stage of varicose vein disease is associated with a higher risk of recurrence. In our study recurrence was defined as reflux in the proximal GSV, which was the treated segment in this study. We cannot fully explain the finding that a refluxing distal GSV at baseline is associated with more recurrences in the proximal GSV. Currently, little is known about the mechanism of recanalisation after UGFS. A hypothesis might be that just treating reflux in the proximal GSV may not result in sufficient haemodynamic modifications to prevent a recurrence (recanalisation) ${ }^{12}$. Another hypothesis is that, in the presence of distal GSV reflux and diameter $>6 \mathrm{~mm}$, the higher reflux volume might prevent adequate damage of the endothelial cells and effective thrombosis and formation of a fibrous cord afterwards. Vascular fibrosis and obliteration only occur after irreversible destruction of the endothelial and subendothelial cellular layers of the treated vein segment ${ }^{13}$. 
The question that arises is whether a refluxing GSV with extended reflux below the knee needs to be treated both proximally and distally in one session. According to Kostas et al. the appropriate length of stripping should be based on the extent of reflux seen by duplex. They found significantly more recurrences in the tibial area with restricted GSV stripping than in limbs with total GSV stripping ${ }^{14}$. Theivacumar et al. did show similar outcomes for endovenous laser ablation (EVLA) after 12 weeks ${ }^{15}$. The results in this study may also provide arguments to start ablation from the lowest point of axial vein reflux. Leaving distal reflux untreated may promote further reflux that can be essential for developing signs and symptoms of CVD ${ }^{16}(16)$. An advantage of UGFS might be that if the below knee GSV is concomitantly treated the risk of nerve injury is probable less than with thermal ablation and surgery. An alternative option, is a more conservative way of approaching patients with a more extended varicose venous reservoir and to investigate if ablation of the proximal trunk has resulted in an absence of reflux in the distal GSV.

This study had some limitations. First, in this study no distinction can be made between predictors of persistent reflux or early/mid term recurrences as the first moment of followup after treatment was at 3 months. Therefore, it was not possible to evaluate whether mechanisms underlying very early failures may be different from those underlying later failures. Second, in the original RCT we primarily focussed on the treatment of the proximal trunk which may have resulted in a relatively high percentage of recurrent saphenous reflux. In conclusion, this prospective study has shown that UGFS treatment for the proximal GSV is less effective for patients with a large vein, a refluxing distal GSV and C4-C5 at baseline. As the results in the present study and other studies ${ }^{15,16}$ suggest that a more extended stage of varicose veins or untreated reflux is associated with a higher risk of recurrence and progression of CVD it may be preferable to treat all the refluxing veins in one session. The findings need to be validated in further prospective studies. 


\section{References}

1. Evans CJ, Fowkes FG, Ruckley CV, Lee AJ. Prevalence of varicose veins and chronic venous insufficiency in men and women in the general population: Edinburgh Vein Study. J Epidemiol Community Health. 1999;53(3):149-53.

2. Eberhardt RT, Raffetto JD. Chronic venous insufficiency. Circulation. 2005;111(18):2398-409.

3. Kanwar A, Hansrani M, Lees T, Stansby G. Trends in varicose vein therapy in England: radical changes in the last decade. Ann R Coll Surg Engl. 2010;92(4):341-6.

4. Nijsten T, van den Bos RR, Goldman MP, Kockaert MA, Proebstle TM, Rabe E, et al. Minimally invasive techniques in the treatment of saphenous varicose veins. J Am Acad Dermatol 2009;60(1):110-9.

5. Shadid N, Ceulen R, Nelemans P, Dirksen C, Veraart J, Schurink GW, et al. Randomized clinical trial of ultrasound-guided foam sclerotherapy versus surgery for the incompetent great saphenous vein. $\mathrm{Br} \mathrm{J}$ Surg. 2012;99(8):1062-70.

6. Wright D, Gobin J, Bradbury A. Varisolve polidocanol microfoam compared with surgery or sclerotherapy in the management of varicose veins in the presence of trunk vein incompetence: European randomized controlled trial. Phlebology 2006;21(4):180-90(11).

7. Labropoulos N, Leon L, Kwon S, Tassiopoulos A, Gonzalez-Fajardo JA, Kang SS, et al. Study of the venous reflux progression. J Vasc Surg 2005;41(2):291-5.

8. Shadid N, Ceulen R, Nelemans P, Dirksen C, Veraart J, Schurink GW, et al. Randomized clinical trial of ultrasound-guided foam sclerotherapy versus surgery for the incompetent great saphenous vein. $\mathrm{Br} \mathrm{J}$ Surg. 2012.

9. Hosmer DL, S. Applied logistic Regression. 2nd ed Wiley\&Sons, Inc. 2000.

10. Myers KA, Jolley D, Clough A, Kirwan J. Outcome of ultrasound-guided sclerotherapy for varicose veins: medium-term results assessed by ultrasound surveillance. Eur JVasc Endovasc Surg2007;33(1):116-21.

11. Gonzalez-Zeh R, Armisen R, Barahona S. Endovenous laser and echo-guided foam ablation in great saphenous vein reflux: one-year follow-up results. J Vasc Surg 2008;48(4):940-6.

12. Pittaluga $P$, Chastanet $S$, Locret $T$, Barbe $R$. The effect of isolated phlebectomy on reflux and diameter of the great saphenous vein: a prospective study. Eur J Vasc Endovasc Surg 2010;40(1):122-8.

13. Chen $\mathrm{CH}$, Chiu $\mathrm{CS}$, Yang $\mathrm{CH}$. Ultrasound-guided foam sclerotherapy for treating incompetent great saphenous veins--results of 5 years of analysis and morphologic evolvement study. Dermatol Surg. 2012;38(6):851-7.

14. Kostas TT, loannou CV, Veligrantakis M, Pagonidis C, Katsamouris AN. The appropriate length of great saphenous vein stripping should be based on the extent of reflux and not on the intent to avoid saphenous nerve injury. J Vasc Surg 2007;46(6):1234-41.

15. Theivacumar NS, Dellagrammaticas D, Mavor Al, Gough MJ. Endovenous laser ablation: does standard above-knee great saphenous vein ablation provide optimum results in patients with both above- and below-knee reflux? A randomized controlled trial. J Vasc Surg 2008;48(1):173-8.

16. Labropoulos N, Giannoukas AD, Delis K, Mansour MA, Kang SS, Nicolaides AN, et al. Where does venous reflux start? J Vasc Surg 1997;26(5):736-42. 


In the treatment of varicose veins, surgery is still the standard treatment in many hospitals, but in the last decades there has been an impressive change in management of patients with varicose veins. A trend can be observed towards treating varicose veins by less invasive techniques such as foamsclerotherapy and thermal endovenous ablation techniques ${ }^{1,2}$. These minimally invasive techniques are considered attractive alternatives because of their efficacy in eliminating venous reflux without the side effects of an invasive surgical technique ${ }^{1,3}$. In combination with the high success rates this technique is attractive for physicians and patients are satisfied by the procedures and the short recovery period ${ }^{4-6}$. Moreover, minimally invasive techniques can be performed under local anaesthesia instead of general anaesthesia and are associated with lower treatment costs ${ }^{4}$. Such cost savings are expected to have considerable impact on national health care budgets, because prevalence of varicose veins is high7. However, new and promising treatments need critical appraisal with regard to effectiveness, evidence is required that cost savings can be achieved without compromising health and prognosis of individual patients.

This thesis addresses cost-effectiveness of foam sclerotherapy which was evaluated in a non-inferiority randomized controlled trial performed in three Dutch hospitals. The results show that replacing surgery by UGFS would result in a cost reduction of more than $€ 1000$ per patient, whereas UGFS treatment is not inferior to surgery when presence of reflux in combination with symptoms is considered as primary outcome measure. In this scenario, it is assumed that only patients with recurrent reflux associated with venous symptoms are candidates for re-treatment sessions of UGFS. In the trial, 40 of 230 patients (17.4\%) patients had a repeat session and despite the need for these additional treatments UGFS is still cheaper than surgery because of the lower costs of the procedure. The finding that 27 patients assigned to surgery withdrew from the study before the start of treatment compared to 3 patients assigned to UGFS supports the notion that patients tend to prefer less invasive treatment to surgery.

The conclusion regarding non-inferiority of UGFS to surgery largely depends on the definition of success, because the proportion of patients with recurrent reflux irrespective of presence of symptoms was considerably higher than the proportion of patients with both reflux and symptoms. Thus, if success is defined as obliteration of reflux, the 2-year probability of failure was significantly lower in patients treated by surgery than in patients treated by UGFS ( $21 \%$ versus $35 \%$ ) and non-inferiority of UGFS could no longer be excluded. These results are in line with the findings in another recently published randomized trial by Rasmussen et $\mathrm{al}^{8}$, that compared UGFS as well as endovenous laser ablation (EVLA) and radio frequency ablation (RFA) with surgical stripping. With regard to elimination of GSV reflux, UGFS was significantly less effective than the other methods. At one year after treatment 
$16.3 \%$ of GSVs treated with foam were refluxing versus $5.8 \%$ after EVLA, $4.8 \%$ after RFA and $4.8 \%$ after surgery. Symptom severity and quality of life scores improved significantly in all treatment groups with no differences between groups. The mean costs were lowest in the UGFS group.

These findings raise the question how success after treatment for varicosity needs to be defined. Should treatment success be defined in terms of anatomical results, i,e abolishing of reflux, or should presence of symptoms also be taken into account? In most studies outcome after varicose veins treatment is defined as the abolishing of reflux or occlusion of the vein in case of endovenous ablation techniques ${ }^{8-10}$. But in daily practice, indication for re-treatment is often guided by persistence of symptoms ${ }^{11}$. If patients do not present with subjective complaints, there is often no reason for referral to examination of the treated vein by ultrasound or further treatment. The choice for presence of reflux in combination with presence of symptoms as primary outcome measure is therefore consistent with a pragmatic approach and daily practice.

However, it may be argued that persistence or recurrence of reflux should be the focus of interest, because it may be a better indicator of prognosis. From a pathophysiological viewpoint recurrent reflux puts the patients at risk for further deterioration of the venous system ${ }^{12}$. Untreated reflux may lead to progression of CVI with an increased risk of skin changes and ulceration. The increased risk of future complications would support an approach towards also treating reflux in patients who do not have symptoms. A problem is that the evidence base for such an approach is limited. Most patients with symptomatic primary disease are treated early after presentation and therefore the rate of progression from C2 varicose veins to skin changes and ulceration is not known ${ }^{13}$. Until now, as neither the cause of venous disease nor the disease progression are fully understood, the discussion about the optimal treatment outcome remains to be decided.

An outcome addressing both anatomical success and symptom relief fits in with a growing interest for reporting effectiveness of medical interventions in terms of subjective measures in addition to objective measures. Patient-reported outcomes such as relief of symptoms and improvement in health related quality of life are considered to be more relevant to patients than outcomes that merely reflect anatomic and morphological features ${ }^{14}$. Several intervention studies have demonstrated that ablation of incompetent superficial veins leads to substantial symptom relief and superior quality of life ${ }^{15,16}$. The rising interest in measuring subjective health outcomes has led to development of questionnaires that measure symptom and quality of life scores. But validity of these questionnaires may be compromised by poor correlation between venous symptoms and presence of CVI and 
reflux ${ }^{11,17}$. The finding that after UGFS many patients with recurrent reflux did not report any symptoms raised the question to what extent symptoms that are commonly attributed to a venous cause can discriminate between patients with and without reflux. This question prompted a study which compared the prevalence of venous symptoms between a group of patients with CVI and reflux and a group of patients with other diseases with leg symptoms, such as arthrosis, peripheral arterial disease, or spinal disc herniation. In this study using a validated questionnaire on symptom frequency, only small differences in prevalence of reported "venous" symptoms were observed between the compared groups. It was shown that patients with CVI were more likely to experience symptoms at the end of the day, but based on all other items CVI could not obviously be differentiated from other leg diseases. There seems need for improvement of questionnaires on symptom scores, including specific questions about circumstances that elicit and exacerbate or alleviate symptoms. Questionnaires could also benefit from more detailed descriptions of sensations. From daily practice we know, that patients with venous complaints describe a pain in the lower legs, they feel the sensation of creeping ants on the skin and they feel the need to elevate their legs whenever possible.

UGFS has been performed for some decades now and seems to be a safe therapy. The main concern for every physician is the occurrence of the most serious adverse event: a thromboembolic complication. The risk of a thromboembolic event after treatment with UGFS is reported to be approximately $1 \%^{18}$. The results in this thesis support the reported low risk of thromboembolic complications. UGFS initiates coagulation pathways, but there is no evidence that this activation results in a hypercoagulable state in peripheral blood after treatment, at least in patients without apparent thrombophilic defects. Little is known about the use of UGFS in patients with coagulation disorders such as Factor V Leiden and protein C or S deficiency. Future (in vitro) studies may be desirable to investigate whether use of UGFS in patients with coagulation disorders augment the risk on thromboembolic events.

The question was also addressed how the treatment with UGFS and the indications for the use of UGFS can be optimized. UGFS for the incompetent GSV is effective in about 2 of 3 patients. The probability of persistent success decreases in the presence of a large diameter, refluxing distal GSV or C4-C5 at baseline. GSVs larger than $6 \mathrm{~mm}$ are more prone for treatment failures after 2 years and other endovenous thermal ablation techniques or varicose vein surgery may thus be better treatment options in larger veins. Furthermore, the effectiveness of foam may be improved if GSVs are only treated when refluxing distal GSV is absent. An alternative option is to treat the whole length of the refluxing GSV. This approach would be in line with the hypothesis that leaving untreated reflux may promote further reflux. By optimizing selection and treatment, success rates may increase. 
UGFS seems to be a an appropriate method for the treatment of primary GSV incompetence if these veins are smaller than $6 \mathrm{~mm}$ and in the absence of distal GSV reflux. In addition UGFS is a good alternative for non saphenous veins. One of the advantages of UGFS is that it progresses easily into the venous network, whatever its anatomical characteristics are. This feature makes it possible to treat all kinds of complex varicose veins. Especially for the tortuous and recurrent veins after surgery or thermal ablation UGFS is a good option. Small veins with a diameter less than $4 \mathrm{~mm}$ are easily accessible for foam sclerotherapy because a needle or intravenous cannula is used. In addition, UGFS can be used for those veins with segmental recanalizations after endovenous laser or radiofrequency, and also after previous treatment with foam. There is less risk of nerve damage with UGFS than with thermal ablation, but the risk on thrombophlebitis and hyperpigmentation might be higher after UGFS. Of the endovenous ablation techniques UGFS is the least invasive and the direct treatment costs and treatment time are lowest.

Based on the data in this thesis we can conclude that UGFS is a safe and cost-effective minimally invasive approach in treating GSV varicose veins. In the era of new treatment methods guided by ultrasound UGFS has found its place. Both, physicians and patients appreciate the minimal invasiveness of the technique. The indications for UGFS have been sharpened. The optimal way for evaluation of effectiveness of alternative treatments of varicose veins should take into account both patients complaints and anatomical findings. The choice of treatment method should be made on an individual base and therefore the physician should be able to apply different techniques. It remains an important field of discussion which patients should be treated and how we should measure the success of the treatment. Use of UGFS to achieve the relief of symptoms in patients suffering from varicose veins combines the advantages of minimal invasiveness and cost reduction. For this reason, UGFS can be recommended as treatment that can replace more expensive and more invasive techniques. 


\section{References}

1. Beale RJ, Gough MJ. Treatment options for primary varicose veins--a review. Eur J Vasc Endovasc Surg. 2005;30(1):83-95.

2. Cheatle T. The long saphenous vein: to strip or not to strip? Semin Vasc Surg. 2005;18(1):10-4.

3. Darwood RJ, Theivacumar N, Dellagrammaticas D, Mavor Al, Gough MJ. Randomized clinical trial comparing endovenous laser ablation with surgery for the treatment of primary great saphenous varicose veins. Br J Surg. 2008;95(3):294-301.

4. Bountouroglou DG, Azzam M, Kakkos SK, Pathmarajah M, Young P, Geroulakos G. Ultrasound-guided foam sclerotherapy combined with sapheno-femoral ligation compared to surgical treatment of varicose veins: early results of a randomised controlled trial. Eur J Vasc Endovasc Surg. 2006;31(1):93-100.

5. Perkins JM. Standard varicose vein surgery. Phlebology 2009;24 Suppl 1:34-41.

6. Darvall KA, Bate GR, Adam DJ, Bradbury AW. Recovery after ultrasound-guided foam sclerotherapy compared with conventional surgery for varicose veins. Br J Surg. 2009;96(11):1262-7.

7. Callam MJ. Epidemiology of varicose veins. Br J Surg. 1994;81(2):167-73.

8. Rasmussen LH, Lawaetz M, Bjoern L, Vennits B, Blemings A, Eklof B. Randomized clinical trial comparing endovenous laser ablation, radiofrequency ablation, foam sclerotherapy and surgical stripping for great saphenous varicose veins. Br J Surg. 2011;98(8):1079-87.

9. Biemans AA, Kockaert M, Akkersdijk GP, van den Bos RR, de Maeseneer MG, Cuypers P, et al. Comparing endovenous laser ablation, foam sclerotherapy, and conventional surgery for great saphenous varicose veins. J Vasc Surg. 2013 [Epub ahead of print].

10. Darke SG, Baker SJ. Ultrasound-guided foam sclerotherapy for the treatment of varicose veins. Br J Surg. 2006;93(8):969-74.

11. Bradbury A, Evans CJ, Allan P, Lee AJ, Ruckley CV, Fowkes FG. The relationship between lower limb symptoms and superficial and deep venous reflux on duplex ultrasonography: The Edinburgh Vein Study. J Vasc Surg. 2000;32(5):921-31.

12. Labropoulos N, Giannoukas AD, Delis K, Mansour MA, Kang SS, Nicolaides AN, et al. Where does venous reflux start? J Vasc Surg.1997;26(5):736-42.

13. Meissner MH. What is the medical rationale for the treatment of varicose veins? Phlebology 2012;27 Suppl 1:27-33.

14. Shepherd AC, Gohel MS, Lim CS, Davies AH. A study to compare disease-specific quality of life with clinical anatomical and hemodynamic assessments in patients with varicose veins. J Vasc Surg. 2011;53(2): 374-82.

15. Darvall KA, Sam RC, Bate GR, Silverman SH, Adam DJ, Bradbury AW. Changes in health-related quality of life after ultrasound-guided foam sclerotherapy for great and small saphenous varicose veins. J Vasc Surg. 2010;51(4):913-20.

16. Rasmussen LH, Bjoern L, Lawaetz M, Lawaetz B, Blemings A, Eklof B. Randomised clinical trial comparing endovenous laser ablation with stripping of the great saphenous vein: clinical outcome and recurrence after 2 years. Eur J Vasc Endovasc Surg. 2010;39(5):630-5.

17. Langer RD, Ho E, Denenberg JO, Fronek A, Allison M, Criqui MH. Relationships between symptoms and venous disease: the San Diego population study. Arch Intern Med. 2005;165(12):1420-4.

18. Jia X, Mowatt G, Burr JM, Cassar K, Cook J, Fraser C. Systematic review of foam sclerotherapy for varicose veins. Br J Surg. 2007;94(8):925-36. 


Summary 
The fast introduction of UGFS in many medical centres prompted the need for evaluation of the cost-effectiveness and safety of this technique when compared to surgery. This thesis addresses the results of a large multi-centre randomized controlled trial that was initiated to evaluate non-inferiority of UGFS compared to stripping with ligation and the volume of cost savings that could be achieved by implementation of UGFS in clinical practice. Secondary objectives were to explore safety in terms of the effect of foam injection on coagulability of bloods and to identify predictors of treatment success after foam sclerotherapy.

Chapter 1 describes the aims of this thesis. As an introduction it provides a short overview of prevalence, pathogenesis and diagnosis of CVI and reviews the development of minimally invasive interventions aimed at obliterating reflux in veins.

Chapter 2 presents a Dutch foam consensus based on literature and clinical experience of various medical specialists such as dermatologists, vascular surgeons and radiologists, which was organized to achieve standardization of UGFS. Important recommendations concerned the preparation of foam (concentration of sclerosant and volume of foam), location of injection and duration of compression therapy after treatment. The foam that is used is a mixture of $1 \mathrm{ml}$ sclerosant (polidocanol) and $4 \mathrm{ml}$ of air (1:5). Regarding long term results in achieving occlusion of the treated vein it could been shown that $1 \%$ polidocanol is as effective as $3 \%$ polidocanol. Therefore it was decided to use $1 \%$ polidocanol. A maximum volume of $10 \mathrm{cc}$ for the GSV and $5 \mathrm{cc}$ for the SSV is recommended. A slow injection is preferred and the treatment is considered to be successful when venospasm is achieved. The best location to insert a varicose vein with a needle or a18-Fr intravenous cannula is just above the knee in case of a great saphenous vein (GSV) or as distal as possible when a small saphenous vein (SSV) is treated. After treatment, compression therapy during a period of 4 weeks with a foam pad over the treated area for 1 week was recommended.

Chapter 3 presents the results of a multicentre randomized clinical trial that was designed with the underlying hypothesis that UGFS is not inferior to surgery in treating the incompetent great saphenous vein (GSV) when re-treatment sessions are allowed. Patients with one or more venous symptoms in combination with incompetence of the saphenofemoral junction and GSV with a reflux time $>0.5 \mathrm{~s}$ (measured over a distance of at least $20 \mathrm{~cm}$ in the upper leg) were included at three different hospitals in the south of the Netherlands. From October 2005 to December 2007, a total of 460 patients were enrolled and eventually 430 patients underwent the assigned treatment. Withdrawal after randomization and before start of treatment occurred mainly in the surgery group. The primary outcome measure of this study was the cumulative probability of recurrent varicose veins at 2 years after treatment. Recurrence was defined as reflux combined with venous symptoms and 
the non-inferiority margin was set at $10 \%$. Secondary outcomes were presence of recurrent reflux (irrespective of symptoms), reduction of symptoms, health-related quality of life (EQ5D), adverse events and direct hospital costs. Outcomes were evaluated at 3 months, 1 year and two years post treatment.

The probability of recurrence in the UGFS group was $11.3 \%$ compared with $9 \%$ in the surgery group after two years with a difference of $2.3 \%(95 \% \mathrm{Cl}:-4.3$ to $8.1 \%)$. The proportion of patients with reflux irrespective of venous symptoms was significantly higher after UGFS than after surgery: $35 \%$ and $21 \%$, respectively. The difference was $14.0 \%$ (95\% Cl: 4.4 to 22.3\%). Mean changes in Venous Clinical Severity Score (VCSS) and EQ-5D utility score and symptom relief did not differ significantly between treatment groups. The most frequently observed adverse events after GFS were thrombophlebitis and hyperpigmentation (7.4\% and $5.6 \%$ ), parasthesia was most often observed in the surgery group (3\%). One deep venous thrombosis and one pulmonary embolism occurred in the UGFS group. Cost analysis showed mean hospital costs per patient of $€ 774$ for UGFS and $€ 1824$ for surgery. In conclusion UGFS is not inferior to surgery in treating GSV reflux associated with venous symptoms and can lead to cost savings of about $€ 1000$ per patient.

Chapter 4 compares the frequency of symptoms that are commonly attributed to venous disease between 76 patients with CVI and reflux and 74 patients with other leg disease such as arthrosis, spinal disc herniation and peripheral arterial disease ( 25 arthrosis, 23 spinal disc herniation, 26 peripheral arterial disease). The VEINES-QOL/Sym questionnaire was used to measure symptom frequency and severity. This questionnaire includes nine items on venous symptoms (heavy legs, aching legs, swelling, night cramps, heat or burning sensation, restless legs, throbbing, itching, tingling sensation) which are rated on a five-point scale of frequency ( 1 =every day, $2=$ several times a week, $3=$ about once a week, $4=$ less than once a week, $5=$ never). Higher proportions in the CVI group were observed for six symptoms, but between-group differences were small and non-significant. Severity of CVI as classified by the CEAP classification was not associated with higher proportions of patients reporting symptoms except for swelling and itching. The largest difference between the CVD and nonCVI group was observed for time of the day at which symptoms were most intense; patients with CVI were more likely to experience symptoms at the end of the day. These results suggest that these symptoms may be less specific for patients with refluxing veins than is usually assumed. This finding implies that venous symptom questionnaires that address only type and frequency of these symptoms may not be specific enough to identify patients with CVI and reflux. There may be need for improvement of venous symptom questionnaires with more attention for circumstances that exacerbate and alleviate symptoms. 
Chapter 5 illustrates, based on a case report, an event of a deep venous thrombosis following a superficial thrombophlebitis. A few days after UGFS of the distal GSV a female patient developed a superficial thrombophlebitis of the venous dorsal arch which was treated with non-steroidal anti-inflammatory drugs and compression hosiery. Six weeks after weekly follow-up with color duplex sonography, a deep venous thrombosis of the popliteal vein was revealed. Oral anticoagulant therapy was started. The occurrence of a superficial thrombophlebitis that is not located close to the treated vein should be an indication for regular follow-up examinations to prevent missing the occurrence of disease progression and a possible involvement of the deep venous system.

Chapter 6 describes the results of a study with the objective to evaluate whether UGFS induces changes in coagulation parameters, which when compared with baseline may be indicative of an increased risk of thrombotic events. Two other studies have previously reported on in vivo effects of UGFS, but this is the first the study which uses Calibrated Automated Thrombography (CAT). A thrombogram shows thrombin generation over time and relevant CAT parameters are the endogenous thrombin potential (ETP), lag time, peak height (Peak). Lag time is defined as the time to initial thrombin formation in minutes, ETP is the area-under-the-curve representing the presence of thrombin in time and peak height represents the maximal concentration of thrombin formed in plasma in $\mathrm{nM}$. These CAT parameters and more traditional parameters such as thrombin anti-thrombin complexes (TAT), d-dimers, fibrinogen, Von Willebrand ( $\mathrm{vWf} \mathrm{Ag)} \mathrm{factor} \mathrm{and} \mathrm{platelet} \mathrm{derived}$ microparticles (MIPA's) were measured in eight patients before and after treatment with UGFS. Significant changes over time were observed for fibrinogen, D-dimers, vWfAg and TAT complexes and these changes are suggestive of initiation of coagulation pathways. An interesting finding was that ETP and peak height decreased over time, which may be suggestive of a compensatory mechanism. It was concluded that foam sclerotherapy initiates coagulation pathways, but there is no evidence that this activation results in an increased thrombosis risk.

The aim of Chapter 7 was to investigate which clinical characteristics at baseline are predictive variables for recurrence of GSV reflux after one single session of ultrasoundguided foamsclerotherapy (UGFS). Data of patients treated for GSV incompetence with UGFS were derived from the randomized clinical trial described in chapter 3. A total of 225 patients were available for analysis. Treatment after one single session was successful in 120 patients and recurrence of reflux was observed in 105 patients within 2 years of follow-up. Baseline characteristics which were considered as potential predictors of treatment success were gender, age, clinical class of CEAP classification, diameter of GSV, amount of injected foam, presence of distal GSV reflux, presence of AASV reflux and VCSS. Larger GSV diameters 
in the thigh, reflux of the distal GSV and a higher C of the CEAP classification (CEAP 4-5 compared to CEAP 2-3) were associated with increased 2-year cumulative probability of failure. The results provide arguments that a refluxing GSV with extended reflux below the knee needs to be treated both proximally and distally in one session. Leaving distal reflux untreated may promote further reflux that can be essential for developing signs and symptoms of CVI. Furthermore, we can conclude that UGFS treatment for the proximal GSV is less effective for patients with a vein $>6 \mathrm{~mm}$ and might not be the first choice treatment for these patients. 

De snelle introductie van foamechosclerose voor behandeling van chronisch veneuze insufficiëntie (CVI) in vele medische centra noodzaakt evaluatie van de kosteneffectiviteit en veiligheid van deze techniek in vergelijking met chirurgie. Dit proefschrift behandelt de resultaten van een groot multicentre gerandomiseerd onderzoek dat geïnitieerd werd om aan te tonen dat foamechosclerose niet minder effectief is dan crossectomie en te bepalen welke kostenreductie haalbaar is door de foam behandeling toe te passen in de klinische praktijk. Daarnaast behandelt dit proefschrift andere relevante aspecten van foamechosclerose zoals het effect van foam injectie op de bloedstolling en identificatie van patiënt- en ziektekenmerken die de kans op succesvolle verwijdering van reflux door foamechosclerose vergroten.

Hoofdstuk 1 beschrijft de doelstellingen van dit proefschrift. Ter introductie biedt het een overzicht van de prevalentie, pathogenese en diagnose van CVI en bespreekt het de opkomst en de ontwikkeling van minimaal invasieve interventies gericht op het verwijderen van reflux van in venen.

Hoofdstuk 2 behandelt een Nederlandse foam consensus, die werd georganiseerd om standaardisatie te bereiken in de foam behandeling en gebaseerd is op de klinische expertise van diverse medisch specialisten zoals dermatologen, vaatchirurgen en radiologen. Belangrijke aspecten betreffen de bereiding van foam (concentratie sclerosans en volume van foam), locatie van de injectie en duur van de compressie therapie na de behandeling. De foam die wordt gebruikt is een mengsel van $1 \mathrm{ml}$ sclerosant (polidocanol) en $4 \mathrm{ml}$ lucht (1:5). Gebruik van 1\% polidocanol wordt geadviseerd op basis van vergelijkbare lange termijn resultaten van $1 \%$ en $3 \%$ polidocanol in het behalen van occlusie van de behandelde vene. Een maximaal volume van $10 c c$ voor de vena saphena magna (VSM) en $5 c c$ voor de vena saphena parva (VSP) wordt aanbevolen. Een langzame injectie is te prefereren en de behandeling wordt als succesvol beschouwd als venospasme wordt bereikt. De beste locatie om een spatader met een naald of een 18-gauge venflon aan te prikken is net boven de knie in het geval van de VSM of zo distaal mogelijk als de VSP wordt behandeld. Na behandeling wordt compressie therapie gedurende 4 weken met een foam pad over het behandelde gebied voor 1 week aanbevolen.

Hoofdstuk 3 beschrijft de resultaten van een multicentre gerandomiseerd klinisch onderzoek dat is opgezet met de onderliggende hypothese dat foamechosclerose niet inferieur is aan chirurgie voor de behandeling van de insufficiënte vena saphena magna (VSM) als daarnaast ook herbehandelingen zijn toegestaan. Patiënten met één of meer veneuze symptomen in combinatie met insufficiëntie van de saphenofemorale crosse en VSM met een reflux tijd van $>0.5 \mathrm{~s}$ (gemeten over een afstand van minstens $20 \mathrm{~cm}$ in 
het bovenbeen) werden geïncludeerd in drie ziekenhuizen in Zuid Nederland. Tussen oktober 2005 en december 2007, werden in totaal 460 patiënten geïncludeerd. Uiteindelijk ondergingen 430 patiënten de toegewezen behandeling. Terugtrekking na randomisatie en voor de start van de behandeling deed zich met name voor in de chirurgie groep. De primaire uitkomstmaat van deze studie was de cumulatieve kans op recidief varicositas binnen 2 jaar na behandeling. Een recidief werd gedefinieerd als reflux gecombineerd met de aanwezigheid van veneuze symptomen. Een toename van maximaal $10 \%$ recidiefkans werd als acceptabel beschouwd (non-inferiority marge van 10\%). Secundaire uitkomstmaten waren de aanwezigheid van recidief reflux (ongeacht de aanwezigheid van veneuze symptomen), vermindering van symptomen, gezondheid-gerelateerde kwaliteit van leven (EQ-5D), bijwerkingen en directe ziekenhuis kosten. Resultaten werden geëvalueerd bij 3 maanden, 1 jaar en twee jaar na behandeling.

De kans op recidief in de foamechosclerose groep was 11,3\% vergeleken met $9 \%$ in de chirurgie groep na twee jaar met een verschil van $2.3 \%$ (95\% Cl: -4.3 to $8.1 \%)$. Het aantal patiënten met reflux ongeacht de aanwezigheid van veneuze symptomen was significant hoger na foamechosclerose dan na chirurgie: respectievelijk 35\% en $21 \%$. De gemiddelde verandering in de VCSS en EQ-5D utiliteit-score en symptoom verlichting verschilden niet significant tussen de twee behandelde groepen. De meest frequent geobserveerde negatieve effecten na foamechosclerose waren thromboflebitis en hyperpigmentatie $(7.4 \%$ en $5.6 \%)$, paresthesie werd het meest frequent geobserveerd in de chirurgie groep (3\%). Eén diep veneuze trombose en één longembolie traden op in de foamechosclerose groep. Kostenanalyse toonde aan dat de gemiddelde ziekenhuis kosten per patiënt $€ 774$ waren voor foamechosclerose en $€ 1824$ voor chirurgie. Concluderend kan gezegd worden dat UGFS niet inferieur is aan chirurgie voor de behandeling van VSM reflux in patienten met veneuze symptomen en een kostenbesparing van circa $€ 1000$ per patiënt kan opleveren.

Hoofdstuk 4 vergelijkt de frequentie van symptomen die vaak worden toegeschreven aan veneuze ziekte tussen 76 patiënten met CVI en reflux en 74 patiënten met andere beenziektes zoals artrose, wervel hernia en perifere arteriële ziekte (25 artrose, 23 wervelhernia, 26 perifere arteriële ziekte). The VEINES-QOL/Sym-vragenlijst werd gebruikt om symptoom frequentie en ernst van symptomen te meten. Deze vragenlijst bevat 9 items van veneuze symptomen (zware benen, pijnlijke benen, zwelling, nachtelijke krampen, kloppend, jeukend, tintelend gevoel) die worden gescoord op een 5-puntsschaal van frequentie (1=elke dag, $2=$ meerdere malen per week, 3=ongeveer eenmaal per week, 4=minder dan eenmaal per week $5=$ nooit). Hogere proporties in de CVI groep werden gevonden voor zes symptomen, maar de verschillen tussen de groepen waren klein en niet significant. Behalve voor de symptomen zwelling en jeuk, was de ernst van CVI volgens de CEAP classificatie 
niet geassocieerd met hogere proporties patiënten die symptomen rapporteerden. Het grootste verschil tussen de CVI en niet-CVI groep werd geobserveerd voor het tijdstip van de dag waarop de symptomen het meest intens waren; patiënten met CVI hebben meer kans op het ervaren van klachten aan het einde van de dag. Deze resultaten suggereren dat deze symptomen mogelijk minder specifiek zijn voor patiënten met veneuze reflux dan over het algemeen wordt aangenomen. Vragenlijsten voor veneuze symptomen die alleen het type en de frequentie van de symptomen betreffen zijn dus wellicht niet specifiek genoeg om patiënten met CVI en reflux te identificeren. Dit impliceert dat er behoefte is aan een verbetering van vragenlijsten met meer aandacht voor omstandigheden die de klachten verergeren of verlichten.

Hoofdstuk 5 illustreert, gebaseerd op een case report, het optreden van een diep veneuze trombose na een oppervlakkige tromboflebitis. Een paar dagen na foamechosclerose van de distale VSM ontwikkelde een vrouwelijke patiënt een oppervlakkige tromboflebitis van de arcus venosum dorsalis pedis. Deze werd behandeld met ontstekingsremmers (NSAID's) en steunkousen. Zes weken na een wekelijkse follow-up met veneus duplexonderzoek, werd een diepe veneuze trombose van de vena poplitea vastgesteld. Orale anticoagulatie therapie werd gestart. Een oppervlakkige thromboflebitis die niet in de buurt zit van de behandelde vene is een indicatie ivoor frequent follow-up onderzoek. Dit om te voorkomen dat ziekte progressie en de mogelijke betrokkenheid van het diep veneuze systeem worden gemist.

Hoofdstuk 6 beschrijft de resultaten van een studie met als doel te beoordelen of foamechosclerose veranderingen teweeg brengt in coagulatie parameters, die indicatief zijn voor een verhoogd risico op trombotische aandoeningen. Twee andere studies hebben eerder gerapporteerd over in vivo effecten van foamechosclerose, maar dit is de eerste studie die gebruik maakt van gekalibreerde geautomatiseerde trombografie (CAT). Een thrombogram toont thrombine generatie over de tijd en relevante CAT parameters zijn de endogeneous thrombin potential (ETP), lag time en peak height. Lag time wordt gedefinieerd als initiële tijd tot de formatie van thrombine, ETP is het gebied onder de curve dat de aanwezigheid van thrombine in de tijd aangeeft, peak height vertegenwoordigt de maximale concentratie van thrombine die wordt gevormd in plasma. Deze CAT parameters en ook andere parameters zoals trombine anti-trombine complexen (TAT), d-dimeren, fibrinogeen, de Von Willebrand (vWf Ag) factor en van bloedplaatjes afgeleide micropartikels (MIPA's) werden gemeten in acht patiënten voor en na behandeling met foamechosclerose. Significante veranderingen over de tijd werden geobserveerd voor fibrinogeen, d-dimeren, vWfAg en TAT complexen en suggereren de initiatie van de stollingscascade. Een interessante bevinding is dat de CAT parameters ETP en peak height 
juist daalden wat suggestief kan zijn voor een compenserend mechanisme. Deze resultaten tonen aan dat foamechosclerse de stollingscascade initieert, maar er is geen aanwijzing dat deze activatie resulteert in een toegenomen risico op trombose.

Het doel van Hoofdstuk $\mathbf{7}$ is om na te gaan welke klinische karakteristieken voorspellend zijn voor recidief reflux van de VSM na een enkele foamechosclerose sessie. De hiervoor benodigde gegevens waren afkomstig uit de gerandomiseerde trial die in hoofdstuk 3 wordt beschreven. In totaal waren 225 patiënten beschikbaar voor analyse. Behandeling na één enkele sessie was succesvol bij 120 patiënten en een recidiverende reflux binnen 2 jaar na behandeling werd waargenomen in 105 patiënten. Baseline kenmerken die als potentiele voorspellers van een succesvolle behandeling werden meegenomen waren geslacht, leeftijd, C van de CEAP classificatie, diameter van de VSM, volume geïnjecteerde foam, aanwezigheid van distale VSM reflux, aanwezigheid van reflux in de VSM accessoria anterior en VCSS. Grotere kans op recidief werd geobserveerd voor patiënten met grotere GSV diameters in het dijbeen, reflux van de distale VSM en een hogere $C$ van de CEAP classificatie (CEAP 4-5 versus CEAP 2-3). De resultaten wijzen erop dat een VSM met reflux tot onder de knie zowel proximaal als distaal behandeld dient te worden in één sessie. Theoretisch kan het onbehandeld laten van distale reflux verdere reflux in de hand werken en leiden tot de ontwikkeling van verdere tekenen en symptomen van CVI. Andere conclusies zijn dat de UGFS behandeling minder effectief is voor patiënten met een vene diameter van $>6 \mathrm{~mm}$ en daarom wellicht niet de voorkeursbehandeling is voor deze patiënten. 



\section{List of publications and oral presentations}

\section{Publications}

Ceulen RPM., Shadid NH, Sommer A, ZonMW Foam-studie: 'stripping' versus duplexgeleide foamsclerose als behandeling voor een primaire insufficiënte vena saphena magna, Nederlands tijdschrift voor Dermatologie en Venereologie, nummer 5, juni 2006

Shadid N, Thissen C, Van Marion A, Poblete Gutierrez P, Frank J. Lupus erythematosus associated with erythema multiforme: Rowell's syndrome. International Journal of Dermatology 2007, 46(suppl.3)30-32

Shadid N, Frank J, Sommer A, Superficial thrombophlebitis of the venous dorsal arch of the foot and deep venous thrombosis after foam sclerotherapy. Int J Dermatol. 2008 Nov;47 Suppl 1:29-31

Shadid NH, Sommer A, Foam echosclerotherapy for trunk varicositas. Ned Tijdschr Geneeskd. 2009;153:B99. Review. Dutch.

Kockaert MA, Sommer A, Shadid N. Sclerocompressietherapie. In: Neumann HAM, Langendoen SI, de Maeseneer M, Wittens CHA. Handboek flebologie; diagnostiek en behandeling van veneuze ziekten. 1st ed. Houten: Prelum uitgevers; 2011. p. 331-39

Shadid N, Ceulen R, Nelemans P, Dirsken C, Veraart J, Schurink GW, van Neer P, vd Kley J, de Haan E, Sommer A. Randomized clinical trial of ultrasound-guided foam sclerotherapy versus surgery for the incompetent great saphenous vein. Britisch Journal of Surgery 2012;99:1062-1070.

Shadid NH, Sommer A. "C" class in conflict between clinic and duplex. Phlebology, September 18, 2012

Shadid NH, Winnepenninckx V, Henquet CJM. Rowellssyndroom? Nederlands tijdschrift voor Dermatologie en Venereologie, nummer 6, juni 2012

Shadid NH, van der Velden SK, van Oerle R, ten Cate H, Sommer A, P Nelemans. In vivo effects of foamsclerotherapy on coagulation. Phlebology, March 27, 2013 
Shadid NH, Nelemans PJ, Lawson JA, Sommer A. Predictors of recurrence of great saphenous vein reflux following treatment with ultrasound-guided foamsclerotherapy. Phelebology 2013. Submitted.

van der Velden SK, Shadid NH, Nelemans PJ, Sommer A. How specific are venous symptoms for diagnosis of chronic venous disease? Phlebology. Submitted

\section{Oral presentations}

Varicosis and lymphedema from childhood onwards. Annual meeting Dutch association for Dermatology and Venereology, Maastricht, the Netherlands, 2006

Lupus erythematosus associated with erythema multiforme: Rowell's syndrome. Regional evening seminar dermatology: southern Limburg, Maastricht, the Netherlands, 2007

Veneus anatomy. Colour duplex course for dermatologists/vascular surgeons. Organized by, Pie Medical Imaging, Utrecht, The Netherlands, 2007

Preliminary results Foamstudy, Phlebology Congress Cabourg II, France, 2007

Superficial thrombophlebitis of the venous dorsal arch of the foot and deep venous thrombosis after foam sclerotherapy. Regional evening seminar dermatology: southern Limburg, Maastricht, the Netherlands, 2008

Foam, tips and tricks, Annual meeting of the Benelux Society of Phlebology, Maastricht, the Netherlands, 2008

Dutch foamconsensus. Annual meeting of the Benelux Society of Phlebology, Harzé, Belgium, 2009

Foamsclerotherapy study. Pelerin symposium for residents of MUMC+, Maastricht, the Netherlands, 2009

Foamsclerotherapy vs surgery in treating the incompetent great saphenous vein (first year results), XVI world congress of the UIP (Union Internationale de Phlebologie) , Monaco, 2009 
A souvenir of the Persian Empire (cutaneous leishmaniasis). Regional evening seminar dermatology: southern Limburg, Maastricht, the Netherlands, 2010

Foamsclerotherapy vs surgery in treating the incompetent great saphenous vein (two years results)

- EADV 19Th Congress, Gothenborg, Sweden, 2010

- 11th Annual Meeting European Venous Forum, Antwerp, Belgium, 2010

- Venous Forum of the Royal Society of Medicine/British Association of Sclerotherapists meeting; The Royal Society of Medicine, London, England, 2010

The pearls of dermatology (lineair IgA dermatosis). Regional evening seminar dermatology: southern Limburg, Maastricht the Netherlands, 2011

Foamsclerotherapy vs surgery in treating the incompetent great saphenous vein (GSV) (two years results). Bonner Venentage, Bonn, Germany, 2011

Foamsclerotherapy vs surgery in treating the incompetent great saphenous vein and tips and tricks in performing foamsclerotherapy. Venous Forum of the Royal Society of Medicine/ British Association of Sclerotherapists meeting; The Royal Society of Medicine, London, England, 2012

Rowell's syndrome? Annual meeting Dutch association for Dermatology and Venereology, Maastricht, the Netherlands, 2012

Nevi and melanoma. Training for general practioners, Zoetermeer, the Netherlands, 2013 


\section{Curriculum Vitae}

Nadia Shadid werd op 5 september 1976 geboren te Middelburg. Zij groeide op in Amersfoort als oudste van het gezin met twee jongere broers. In 1995 behaalde zij het VWO diploma aan het Eemlandcollege Zuid te Amersfoort. Hetzelfde jaar startte zij haar studie geneeskunde aan de Vrije Universiteit te Amsterdam. In 2000, aan het einde van haar doctoraal fase, vertrok zij voor 8 maanden naar Amerika voor een wetenschappelijke stage op de afdeling pathologie in het Cardinal Glennon Children's Hospital te St. Louis en een rondreis. Van 2001 tot 2003 volgde zij haar co-schappen in en rond Amsterdam, waarvan 4 maanden in Suriname. Aansluitend werd het artsexamen in november 2003 afgelegd. Zij werkte achtereenvolgens een jaar als ANIOS op de afdeling chirurgie van het Amstelland ziekenhuis te Amstelveen en negen maanden op de afdeling nefrologie van het West Fries Gasthuis te Hoorn. Onder begeleiding van Anja Sommer startte zij in februari 2006 als artsonderzoeker op de afdeling dermatologie in het Academisch Ziekenhuis Maastricht. Twee jaar later, startte zij in 2008 naast haar wetenschappelijke werkzaamheden de opleiding tot dermatoloog welke in december 2012 werd afgerond. Sinds februari 2013 is zij werkzaam als dermatoloog in het Medisch Centrum Haaglanden te Den Haag. 



\section{Dankwoord}

Het is zover, het is gelukt! De laatste pagina's die nog gevuld gaan worden. Misschien wel de eerst en meest gelezen pagina's van dit boekje. In ieder geval een tekst die niet heen en weer hoeft te worden gestuurd en vrij zal blijven van correcties en rode strepen. Aan een clichézin ontkom ik niet: "dit proefschrift had niet tot stand kunnen komen zonder de hulp van velen", want zo is het!

Graag wil ik dan ook van de gelegenheid gebruik maken om iedereen die in directe of indirecte zin een bijdrage aan dit proefschrift heeft geleverd te bedanken: heel veel dank!

Een aantal van jullie wil ik in het bijzonder noemen.

In de eerste plaats wil ik alle patiënten bedanken die wilden meewerken aan de inhoud van dit proefschrift. Zonder jullie frequente polikliniek bezoeken en het invullen van de terugkerende, uitgebreide vragenlijsten was een groot deel van dit werk niet tot stand gekomen.

Professor Steijlen, heel veel dank voor het door $u$ in mij gestelde vertrouwen. Ik ben blij dat $u$ mij destijds als arts-onderzoeker heeft aangenomen. Twee jaar later bood u mij de mogelijkheid het onderzoek te combineren met de opleiding tot dermatoloog. Ik heb deze afwisseling als heel prettig ervaren, al was het soms lastig de aandacht goed te verdelen tussen de twee. Ik ben blij dat $\mathrm{u}$ achter mijn keuze stond en het vertrouwen had dat ik het zou afmaken. Dank voor de tijd en ruimte die u creëerde om deze combinatie te realiseren en ervoor te zorgen dat ik op de juiste momenten in de luwte bleef van de dagelijkse klinische werkzaamheden.

Lieve Anja, jij was het die mij de mogelijkheid bood om het Foamproject aan te gaan, de eerste stap naar dit proefschrift. Ik leerde van jou het flebologie vak, te spreken op grote congressen en prioriteiten te stellen. Je was altijd bereid mij thuis te ontvangen in de avonduren en brainstorm sessies te houden over de inhoud en opzet van het proefschrift. Deze avonden werden vaak vergezeld van een heerlijke maaltijd met in de eerste jaren een slapende Lucy naast de keukentafel. Hier vloeiden inspirerende ideeën uit voort die de basis vormen van dit proefschrift. Ik ben blij met de ruimte en vrijheid die je mij ook gaf om mijn eigen ideeën voor het onderzoek vorm te geven. Ik ben je hier heel dankbaar voor! 
Lieve Patty, ik ben je zo dankbaar voor al je betrokkenheid bij het schrijven van dit proefschrift. Zonder jou had dit proefschrift er niet gelegen! Ik kon altijd bij je binnenlopen en tot in de late uurtjes stond je mij te woord aan de telefoon of via de digitale weg. Jouw kritische en grootschalige input met betrekking tot het analyseren van data, opbouw van artikelen en het wetenschappelijke Engels zijn van enorme waarde voor dit proefschrift geweest. Ik heb heel veel van je geleerd. Daarnaast heb ik veel aan je steun gehad, je eindeloze geduld en het vertrouwen dat je uitsprak dat alle resultaten tot een promotie zouden leiden als ik het even niet meer zag zitten. Je hebt gelijk gehad.

James Lawson, jij stond aan de wieg van mijn keuze voor een promotietraject binnen de flebologie. Met heel veel plezier heb ik een jaar bij jullie maatschap als ANIOS chirurgie in het Amstelland ziekenhuis gewerkt. Peter van Aken en jij wisten mijn eerste interesse voor de veneuze pathologie te wekken. Blij verrast was ik toen je belde en vertelde dat je voor 2 jaar op de afdeling dermatologie in Maastricht kwam werken. Veel dank voor de motiverende en prettige samenwerking, alle goede adviezen en flebologische artikelen over de mail.

Lieve Heleen en Evelien, ik vind het heel fijn dat jullie straks op de dag van de verdediging achter mij willen staan als paranimfen. Ik ben heel blij met onze vriendschap. Dank voor alle steun en gezellige momenten zowel op de werkvloer als daarbuiten! Ik kan met alles altijd bij jullie terecht.

Heleen, je luisterend oor, humor en altijd relativerende woorden zijn voor mij heel waardevol. Ik ben blij dat we weer dichtbij elkaar zitten!

Evelien, je eigenheid en creativiteit zijn een enorme inspiratie. Jij wist mij op het juiste moment achter de computer vandaan te halen om een rondje te fietsten in het heuvellandschap of voor een wandeling door het Jekerdal en tussentijds te filosoferen over het leven.

Monique de Laat, heel veel dank voor je tomeloze inzet tijdens het Foamproject. Je hebt honderden duplex onderzoeken uitgevoerd en deed dat steeds weer met hetzelfde enthousiasme. Met heel veel plezier kijk ik terug op onze fijne samenwerking en de maandelijkse autoritjes naar de periferie.

Roeland Ceulen, jij maakte de eerste belangrijke stappen voor het Foamproject zodat het project vanaf de eerste dag goed van start kon gaan. Heel veel dank voor al je uitleg, meedenken en het wegwijs maken met het duplexonderzoek en de foamechosclerose.

Rene Estourgie, Ed de Haan, Geert Willem Schurink, Joost van der Kley en Pierre van Neer veel dank voor al het werk dat jullie hebben verzet om tot het gevraagde aantal inclusies te komen. Het was altijd leuk om een dagdeel bij jullie in de periferie te werken. 
Professor Dirksen, Carmen, veel dank voor je waardevolle en wetenschappelijke bijdrage aan het Foamproject. Zonder jouw begeleiding van de kosteneffectiviteitsanalyse was het voor mij niet mogelijk geweest de "geld" bomen door het bos te zien.

Professor ten Cate en Rene van Oerle, toen ik bij jullie kwam met het idee, om onderzoek te doen naar de effecten van foamechosclerose op stolling, waren jullie meteen bereid mee te denken en te werken. Veel dank voor jullie goede en laagdrempelige begeleiding.

Simone van der Velden, heel veel dank voor je hulp bij het stollingsonderzoek en je bijdrage aan de inhoud van hoofdstuk 4. Ik heb heel fijn met je samengewerkt! Ook jouw promotie gaat zeker lukken!

Joep Veraart, dank voor je interesse in de vorderingen van het Foamproject en mijn proefschrift, je was altijd bereid mee te denken.

Jorge Frank, dank voor het kritisch meelezen tijdens het schrijven van de thromboflebitisDVT casus.

Alle dames van de polikliniek dank voor jullie hulp en ondersteuning tijdens de flebologie spreekuren. Marie-Paule in het bijzonder, jij zorgde ervoor dat de studie patiënten op tijd voor de follow-up werden opgeroepen.

Dames van het secretariaat, met jullie eerste groet en een praatje begon de dag altijd goed. Lieve Annelies en Ingrid, heel veel dank voor al jullie administratieve werk rond het Foamproject. Nicole en Petra dank voor jullie hulp, jullie waren altijd van alles op de hoogte! Annelies en Nicole, jullie hulp en ondersteuning bij de" laatste loodjes" was onmisbaar!

Lieve "oud" collega assistenten jullie hebben mijn tijd in Maastricht een extra dimensie gegeven. Jullie zorgden naast jullie collegialiteit en prettige samenwerking voor vele uurtjes ontspanning. Koffie drinken in het keukentje, biertjes in de Thembi, de etentjes thuis en uurtjes sporten. De jaarlijkse assistenten weekenden en skireisjes zijn onvergetelijk! Heel veel dank voor deze fantastische tijd!

Promotie partners in crime; Klara, Charlene, Valerie, Sadhanna, Annemoon, Aimee en Annet. De uren op een uitgestorven Oxford waren vaak productief en motiverend, maar ook heel gezellig. Het was fijn om met jullie de ups-and-downs van het promoveren te delen.

Sharon en Lieke, dank voor alle steun en gezellige uurtjes samen! 
Ik wil alle stafleden van de dermatologie in Maastricht bedanken voor het opleiden en jullie interesse. Ook mede namens jullie steun en medewerking was het voor mij mogelijk om het onderzoek te combineren met de opleiding.

Dermatologen uit het Medisch Centrum Haaglanden, ik ben blij dat ik met jullie samenwerk!

Lieve vrienden en (schoon) familie, ook al was het voor velen misschien niet altijd duidelijk waar ik veel van mijn tijd mee vulde de afgelopen jaren, jullie vriendschap, gezelligheid en steun was en is van wezenlijk belang. Dank voor alle fijne tijd en ontspanning ook al zat een groot aantal van jullie zo'n 200 km of nog meer verderop. Ik kijk uit naar de "promotieloze" tijd met jullie!

Lieve pap en mam, door jullie onvoorwaardelijke steun en liefde heb ik alle vrijheid gehad om mezelf te ontwikkelen en vormen tot wie ik ben. Jullie vaak wijze raad, positieve levenshouding en onuitgesproken woorden: "geniet van het leven, maar werk ook hard" zijn zeer waardevol geweest. Jullie hebben er altijd voor gezorgd dat er een warm thuis was en is, ik mag van geluk spreken met zulke ouders.

Mam, de cover is prachtig. Dit boekje is voor jullie!

Lieve Haroun en Marwan, ik ben heel blij met jullie als broers en onze goede band! Veel mooie herinneringen aan het samen groot worden en later de gezamenlijke weken in de Franse zon en winterse Alpen met aanhang. Ik hoop dat we dit nog lang mogen voortzetten. Haroun, we komen jullie snel opzoeken in Singapore!

Lieve Daniel, jij geeft mij zoveel liefde en energie! Jouw gedrevenheid in alles wat je doet werkt aanstekelijk. Je bent een heel belangrijke motor voor dit proefschrift geweest. Dank voor alles, maar vooral dat je bent wie je bent!

Lieve Yara, jouw ontwapende lach en verwondering voor de kleine dingen om je heen doen mij beseffen wat echt belangrijk is in het leven. Ik verheug mij op een toekomst met vier en kijk uit naar weer meer tijd samen. Ik hou van jullie! 